DOE/ID-22142

\title{
Stratigraphy of the Unsaturated Zone and the Snake River Plain Aquifer at and near the Idaho National Engineering Laboratory, Idaho
}

Nov $2 \div 1937$

$$
\text { OSTI }
$$

U.S. Geological Survey

Water-Resources Investigations Report 97-4183

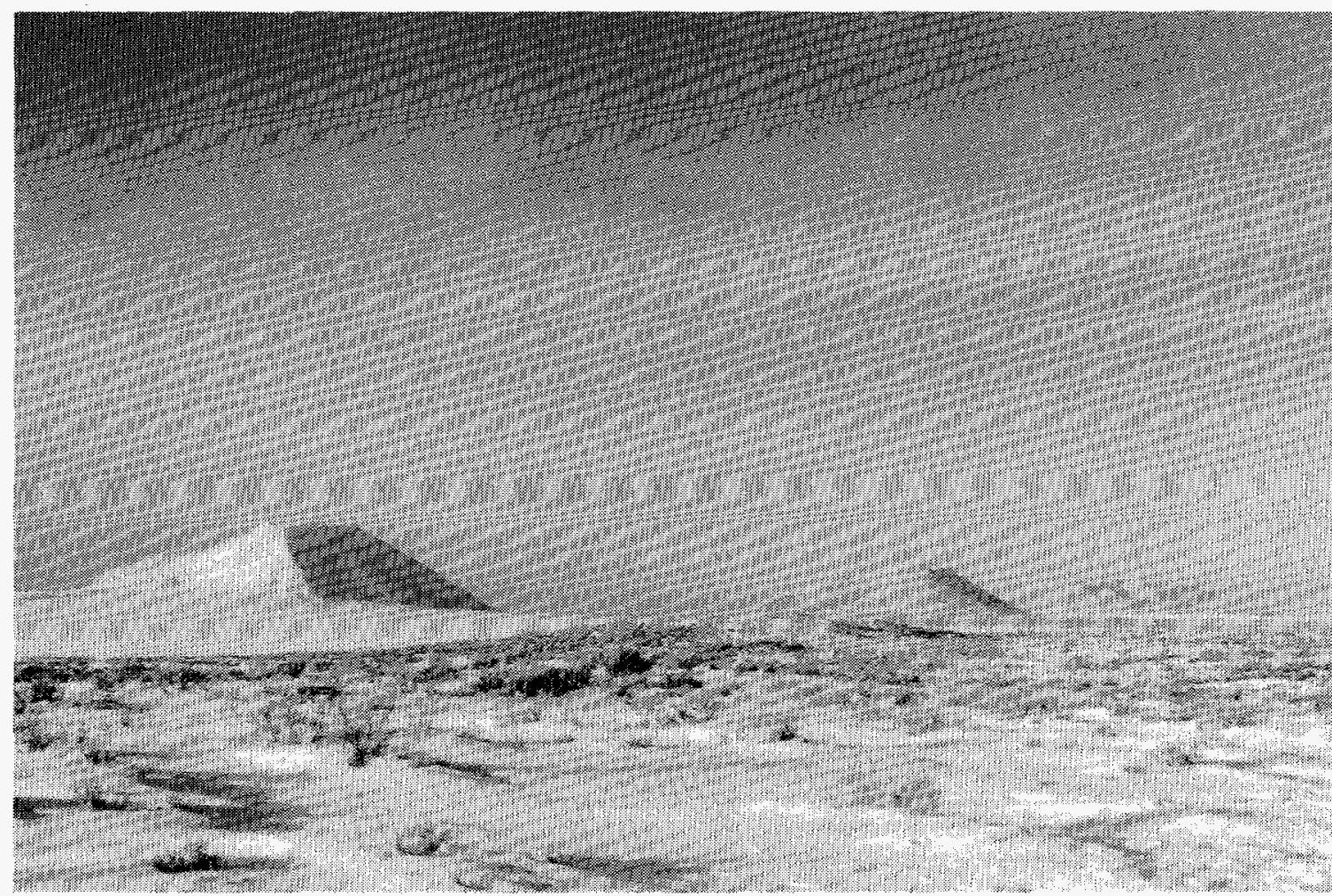

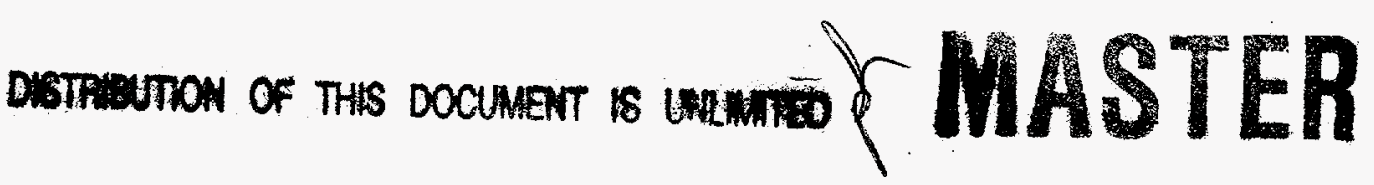

Prepared in cooperation with the U.S. DEPARTMENT OF ENERGY

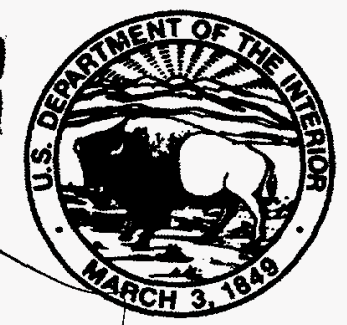




\section{Stratigraphy of the Unsaturated Zone and the Snake River Plain Aquifer at and near the Idaho National Engineering Laboratory, Idaho}

By S.R. Anderson and Michael J. Liszewski

U.S. GEOLOGICAL SURVEY

Water-Resources Investigations Report 97-4183

Prepared in cooperation with

U.S. DEPARTMENT OF ENERGY

Idaho Falls, Idaho

August 1997

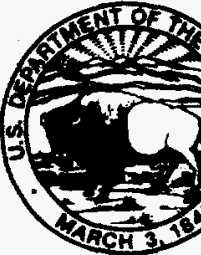




\title{
U.S. DEPARTMENT OF THE INTERIOR \\ BRUCE BABBITT, Secretary
}

\author{
U.S. GEOLOGICAL SURVEY
}

GORDON P. EATON, Director

Any use of trade, produce, or firm names in this publication is for descriptive purposes only and does not constitute endorsement by the U.S. Government

For additional information write to:

U.S. Geological Survey

INEL, MS 4148

P.O. Box 2230

Idaho Falls, ID 83403
Copies of this report can be purchased from:

U.S. Geological Survey Information Services

Box 25286, Federal Center

Denver, CO 80225-0286 


\section{DISCLAIMER}

This report was prepared as an account of work sponsored by an agency of the United States Government. Neither the United States Government nor any agency thereof, nor any of their employees, makes any warranty, express or implied, or assumes any legal liability or responsibility for the accuracy, completeness, or usefulness of any information, apparatus, product, or process disclosed, or represents that its use would not infringe privately owned rights. Reference herein to any specific commercial product, process, or service by trade name, trademark, manufacturer, or otherwise does not necessarily constitute or imply its endorsement, recommendation, or favoring by the United States Government or any agency thereof. The views and opinions of authors expressed herein do not necessarily state or reflect those of the United States Government or any agency thereof. 


\section{DISCLAIMER}

Portions of this document may be illegible electronic image products. Images are produced from the best available original document. 


\section{CONTENTS}

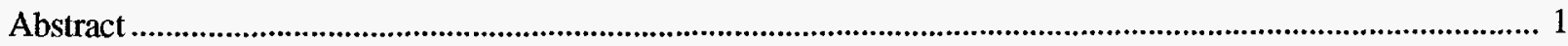

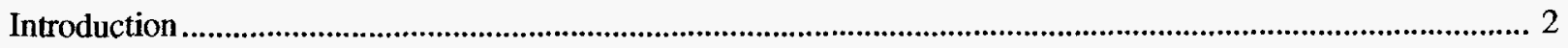

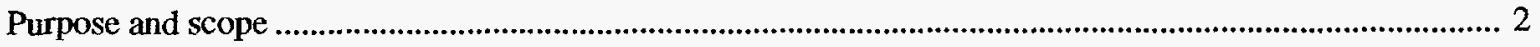

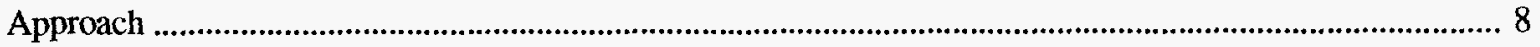

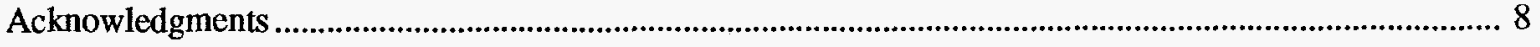

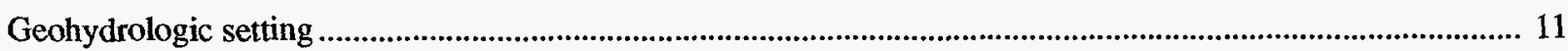

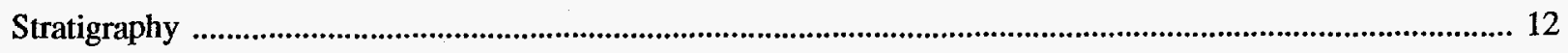

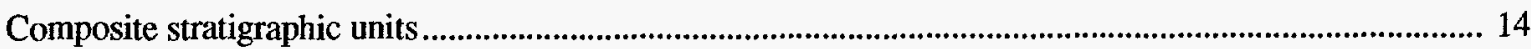

Composite stratigraphic unit 1 .......................................................................................................... 14

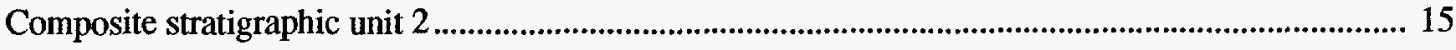

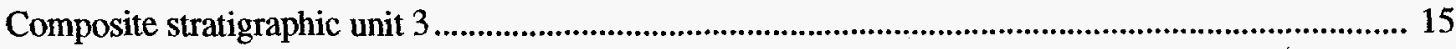

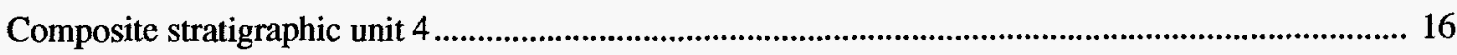

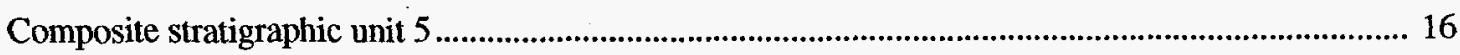

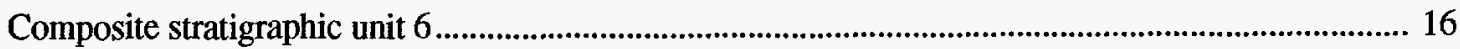

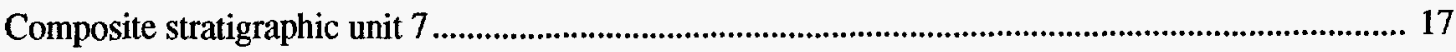

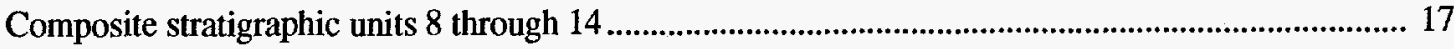

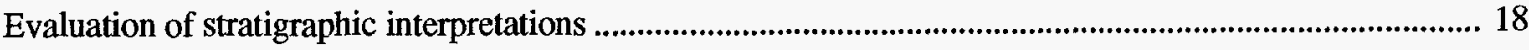

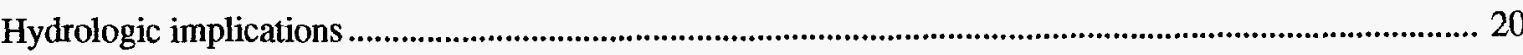

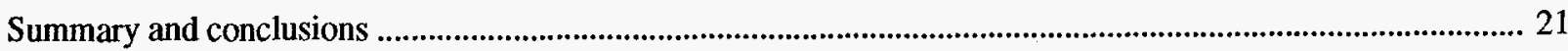

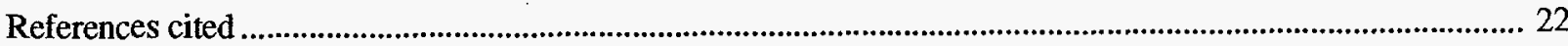

FIGURES

\section{1-8. Maps showing:}

1. Location of the Idaho National Engineering Laboratory and selected facilities ................................................ 3

2. Locations of wells at and near the Idaho National Engineering Laboratory for which stratigraphic data are available.

3. Locations of wells at and near the Idaho Chemical Processing Plant, Test Reactor Area, and Central Facilities Area for which stratigraphic data are available.

4. Locations of wells at and near the Radioactive Waste Management Complex for which stratigraphic data are available.

5. Locations of wells at and near the Contained Test Facility and Test Area North for which stratigraphic data are available.

6. Locations of selected wells and cores used to evaluate geologic ages, accumulation rates, stratigraphy, and structure of basalt-flow groups and sedimentary interbeds in the unsaturated zone and the Snake River Plain aquifer at and near the Idaho National Engineering Laboratory.

7. Locations of selected volcanic vents at and near the Idaho National Engineering Laboratory 10 
8. Locations of geologic sections A-A' through E'-E" at and near the Idaho National Engineering Laboratory

Geologic sections:

9. A-A' at the Idaho National Engineering Laboratory. 28

10. B-B' at the Idaho National Engineering Laboratory ........................................................................................... 29

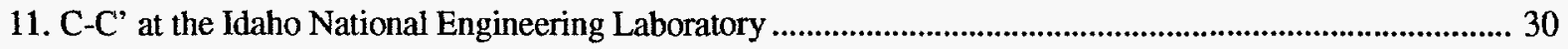

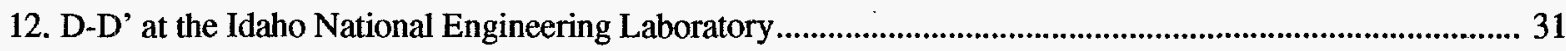

13. D'-D" at the Idaho National Engineering Laboratory ............................................................................... 32

14. E-E' at the Idaho National Engineering Laboratory....................................................................................... 33

15. E'-E" at the Idaho National Engineering Laboratory ........................................................................................ 34

16-30. Maps showing:

16. Thickness of composite stratigraphic unit 1 at the Idaho National Engineering Laboratory ......................... 35

17. Altitude of the top of composite stratigraphic unit 2 at the Idaho National Engineering Laboratory............ 36

18. Thickness of composite stratigraphic unit 2 at the Idaho National Engineering Laboratory ........................ 37

19. Altitude of the top of composite stratigraphic unit 3 at the Idaho National Engineering Laboratory............ 38

20. Thickness of composite stratigraphic unit 3 at the Idaho National Engineering Laboratory .......................... 39

21. Altitude of the top of composite stratigraphic unit 4 at the Idaho National Engineering Laboratory............ 40

22. Thickness of composite stratigraphic unit 4 at the Idaho National Engineering Laboratory ......................... 41

23. Altitude of the top of composite stratigraphic unit 5 at the Idaho National Engineering Laboratory............ 42

24. Thickness of composite stratigraphic unit 5 at the Idaho National Engineering Laboratory ......................... 43

25. Altitude of the top of composite stratigraphic unit 6 at the Idaho National Engineering Laboratory............ 44

26. Thickness of composite stratigraphic unit 6 at the Idaho National Engineering Laboratory ......................... 45

27. Altitude of the top of composite stratigraphic unit 7 at the Idaho National Engineering Laboratory............. 46

28. Thickness of composite stratigraphic unit 7 at the Idaho National Engineering Laboratory ......................... 47

29. Altitude of the top of combined composite stratigraphic units 8 through 14 at the Idaho National Engineering Laboratory

30. Thickness of combined composite stratigraphic units 8 through 14 at the Idaho National

Engineering Laboratory

\section{TABLES}

1. Wells at and near the Idaho National Engineering Laboratory for which stratigraphic data are available

2. Selected cores and sources of data used to evaluate stratigraphic units underlying the Idaho National

Engineering Laboratory

3. Wells that penetrate the effective base of the Snake River Plain aquifer at the Idaho National

Engineering Laboratory 
4. Stratigraphic units on or underlying the Idaho National Engineering Laboratory and adjacent areas

5. Measured and estimated geologic ages of selected basalt-flow groups underlying the Idaho National Engineering Laboratory and adjacent areas.

6. Paleomagnetic chrons and subchrons in cores at and above the effective base of the Snake River Plain aquifer at the Idaho National Engineering Laboratory

7. Summary of composite stratigraphic units 1 through 14 at and near the Idaho National Engineering Laboratory

8. Measured and estimated geologic ages of selected surficial stratigraphic units at and near the Idaho National Engineering Laboratory.

9. Average sediment content of composite stratigraphic units 1 through 7 in selected wells east through southwest of Test Area North at the Idaho National Engineering Laboratory

CONVERSION FACTORS AND VERTICAL DATUM

\begin{tabular}{rcc}
\hline Multiply & By & To obtain \\
\hline foot $(\mathrm{ft})$ & 0.3048 & meter \\
mile (mi) & 1.609 & kilometer \\
square mile $\left(\mathrm{mi}^{2}\right)$ & 2.590 & square kilometer \\
\hline
\end{tabular}

Sea level: In this report, "sea level" refers to the National Geodetic Vertical Datum of 1929-a geodetic datum derived from a general adjustment of the first-order level nets of the United States and Canada, formerly called Sea Level Datum of 1929. 


\title{
Stratigraphy of the Unsaturated Zone and the Snake River Plain Aquifer at and near the Idaho National Engineering Laboratory, Idaho
}

\author{
by S.R. Anderson and Michael J. Liszewski
}

\begin{abstract}
The unsaturated zone and the Snake River Plain aquifer at and near the Idaho National Engineering Laboratory (INEL) are made up of at least 178 basalt-flow groups, 103 sedimentary interbeds, 6 andesite-flow groups, and 4 rhyolite domes. Stratigraphic units identified in 333 wells in this $890-$ mile $^{2}$ area include 121 basalt-flow groups, 102 sedimentary interbeds, 6 andesiteflow groups, and 1 rhyolite dome. Stratigraphic units were identified and correlated using the data from numerous outcrops and 26 continuous cores and 328 natural-gamma logs available in December 1993. Basalt flows make up about 85 percent of the volume of deposits underlying the area.
\end{abstract}

Several types of data were used to identify and correlate stratigraphic units. Basalt, sediment, andesite, and rhyolite were identified from outcrops and cores selectively evaluated for paleomagnetic inclination and polarity, potassiumargon and argon-argon geologic ages, petrographic characteristics, and major-oxide and traceelement chemical composition. Stratigraphic units were correlated using these data and naturalgamma logs, which respond to potassium contents of generally less than 1 percent in basalt to more than 4 percent in rhyolite. The best stratigraphic correlations at and near the INEL were obtained for basalt and sediment at the Contained Test Facility (CTF), Test Area North (TAN), the Naval Reactors Area, the Test Reactor Area, the Idaho Chemical Processing Plant, the Central Facilities Area, and the Radioactive Waste Management Complex (RWMC), where most cores and two thirds of the logs were obtained. Correlations range from good for units at the RWMC to uncertain for units in the eastern half of the INEL.
Fourteen composite stratigraphic units, each made up of 5 to 90 stratigraphic units of similar age, are used to describe the stratigraphy of the unsaturated zone and aquifer. Upper and lower boundaries of each composite unit were selected to show the main stratigraphic and structural features underlying the INEL and adjacent areas. Composite unit 1 , the youngest unit, is made up of 78 basalt-flow groups and 12 sedimentary interbeds. Composite unit 14, the oldest unit, is made up of 4 basalt-flow groups and 1 sedimentary interbed. The decrease in the number of stratigraphic units assigned to each successively older composite unit is attributed partly to larger and less-frequent volcanic eruptions during the accumulation of these units and partly to the limited distribution of available cores used to identify stratigraphic units at greater depths in the subsurface. Composite units 1 through 7 generally range in age from about 200 to 800 thousand years and make up the unsaturated zone and the uppermost part of the Snake River Plain aquifer in most places. Composite units 8 through 14 range in age from about 800 thousand to 1.8 million years and make up the unsaturated zone and aquifer at and near the CTF and TAN and the lowermost part of the aquifer elsewhere. Water levels in the aquifer in 1996 coincided with composite units 4 and 5 in most places; water levels coincided with composite unit 12 at and near the CTF and TAN. Hydraulic gradients of the water table range from about 1 to $15 \mathrm{feet} / \mathrm{mile}$, average about $4 \mathrm{feet} / \mathrm{mile}$, and, in places, change abruptly near concealed uplifts in the aquifer. These abrupt changes indicate that dipping layers and increased sediment content of composite stratigraphic units near uplifts may affect the movement of water and waste in the aquifer. 


\section{INTRODUCTION}

The Idaho National Engineering Laboratory (INEL) is operated by the U.S. Department of Energy (DOE) and covers about $890 \mathrm{mi}^{2}$ of the eastern Snake River Plain in eastern Idaho (fig. 1). Facilities at the INEL are used in the development of peacetime atomic-energy applications, nuclear safety research, defense programs, and advanced energy concepts. Liquid radionuclide and chemical wastes generated at these facilities have been discharged to onsite infiltration ponds and disposal wells since 1952. Liquid-waste disposal has resulted in detectable concentrations of several waste constituents in water from the Snake River Plain aquifer underlying the INEL (Bartholomay and others, 1995).

Concern about the potential for migration of radioactive and chemical wastes in the unsaturated zone and aquifer has resulted in numerous studies of the subsurface at the INEL. In 1988, the U.S. Geological Survey (USGS), in cooperation with the DOE, began a site-wide study of the stratigraphy of volcanic and sedimentary units underlying the INEL to determine stratigraphic relations that might affect the movement of wastes. Three early reports from the study, Anderson and Lewis (1989), Anderson (1991), and Anderson and Bowers (1995), describe stratigraphic relations and their implications regarding the movement of wastes at the Radioactive Waste Management Complex (RWMC), the Idaho Chemical Processing Plant (ICPP), the Test Reactor Area (TRA) and Test Area North (TAN) (fig. 1). Four other reports from the study, Anderson and Bartholomay (1995), Anderson and others (1996a), Anderson and others (1996b), and Anderson and others (1997), describe the method used to identify and correlate stratigraphic units, stratigraphic relations of volcanic and sedimentary units in 333 wells, thickness of surficial sediment, and geologic ages and accumulation rates of basalt and sediment in selected wells, respectively, at and near the INEL. Other facilities for which detailed stratigraphic studies were conducted include the Contained Test Facility (CTF), Naval Reactors Facility (NRF), Argonne National Laboratory-West (ANL-W), Central Facilities Area (CFA), and Experimental Breeder Reactor-1
(EBR-1) (fig. 1). Although the early reports contain important geologic discussions, detailed stratigraphic relations and the names used to identify stratigraphic units described therein are superseded by those in Anderson and others (1996a) and this report.

In this report, a stratigraphic unit is defined as the smallest layer of a rock sequence that can be correlated using the data available in December 1993 (Anderson and others, 1996a). Stratigraphic units described in this report include 178 basaltflow groups, 104 sedimentary interbeds, 6 andesite-flow groups, and 4 rhyolite domes. Andesite, following the general usage of Kuntz and others (1994), refers to rocks such as those of Cedar Butte that consist mainly of trachyandesite and trachydacite (Le Bas and others, 1986; Hayden, 1992; Fishel, 1993).

\section{Purpose and Scope}

This report summarizes the results of the sitewide stratigraphic study since 1988 and is the first to describe stratigraphic relations for the entire INEL and adjacent areas. This report describes the distribution of 292 stratigraphic units and 14 composite stratigraphic units that make up the unsaturated zone and the Snake River Plain aquifer at and near the INEL. Stratigraphic units include the 121 basalt-flow groups, 102 sedimentary interbeds, 6 andesite-flow groups, and 1 rhyolite dome described by Anderson and others (1996a) in 333 wells at and near the INEL. Stratigraphic units also include an additional 57 basaltflow groups, 1 sedimentary interbed, and 3 rhyolite domes described by Kuntz and others (1994) at the land surface in areas not penetrated by wells. Each composite stratigraphic unit is made up of 5 to 90 stratigraphic units of similar age. Areal coverage of wells and stratigraphic data in this report corresponds with that of the stratigraphic data base presented by Anderson and others (1996a) and the geologic map presented by Kuntz and others (1994); however, most wells from which data were obtained are within the boundary of the INEL. Wells are concentrated near major facilities (figs. 1-5; table 1, located at the end of this report) and are sparse elsewhere at the INEL. 


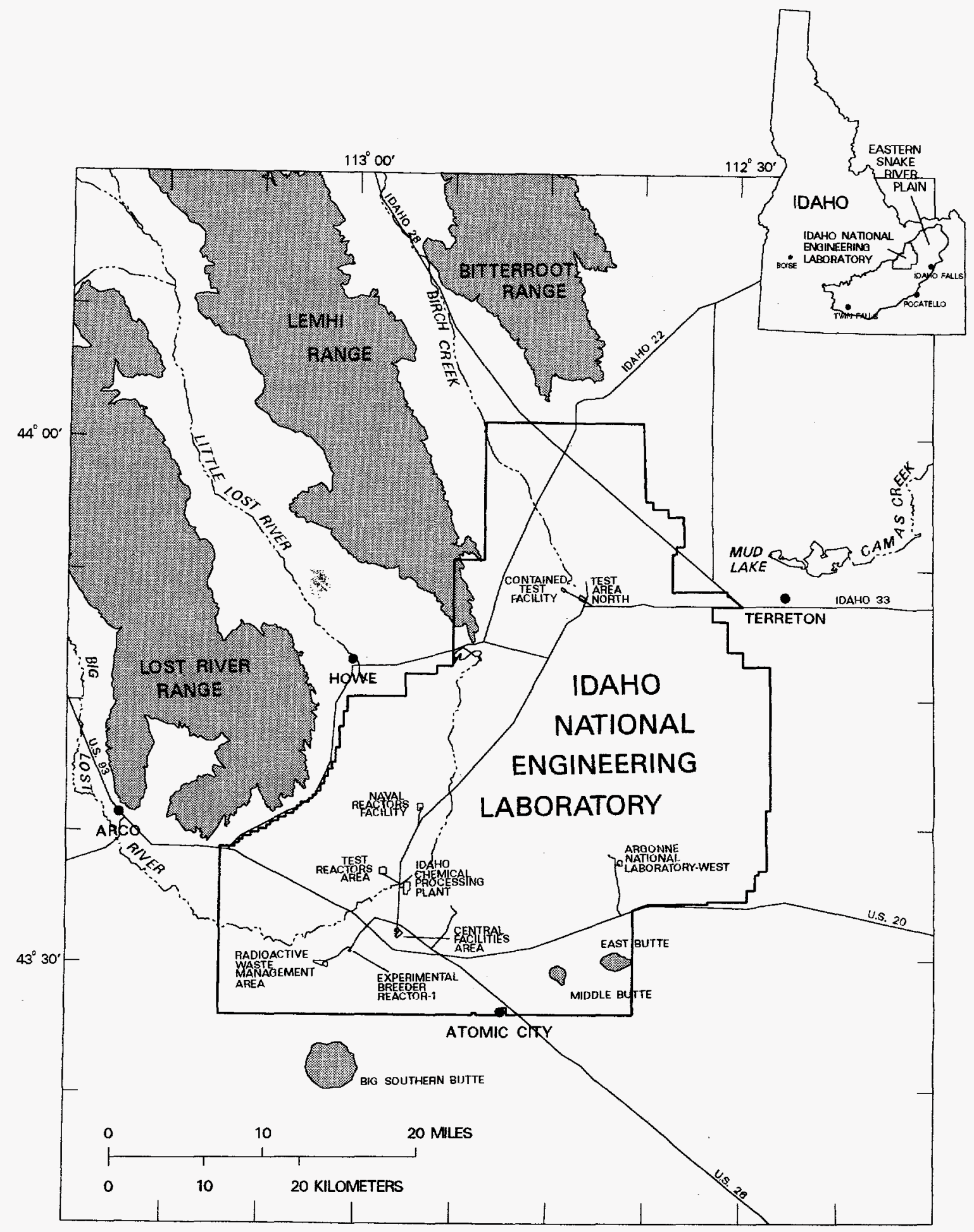

Figure 1. Location of the Idaho National Engineering Laboratory and selected facilities. 


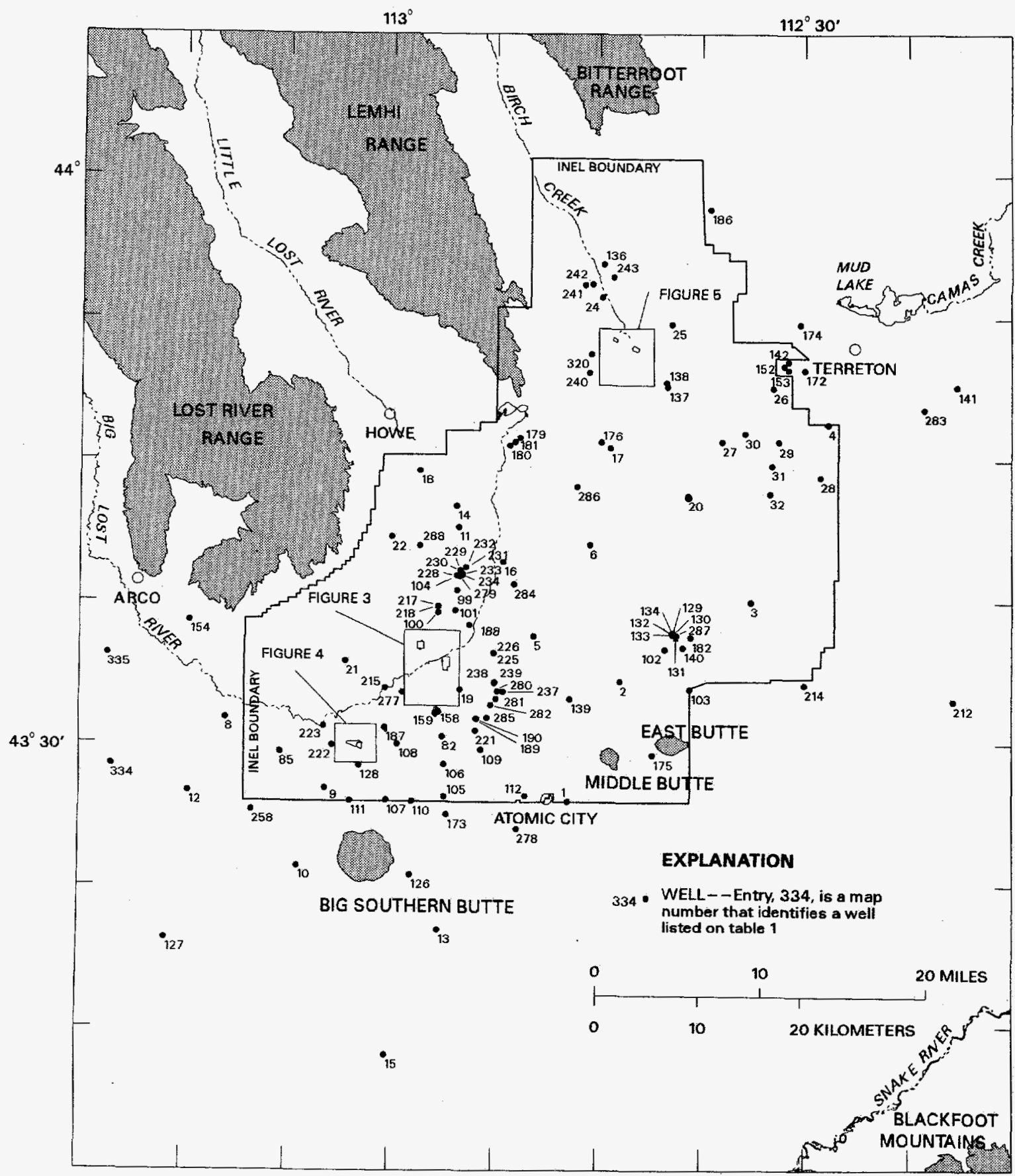

Figure 2. Locations of wells at and near the Idaho National Engineering Laboratory for which stratigraphic data are available. 


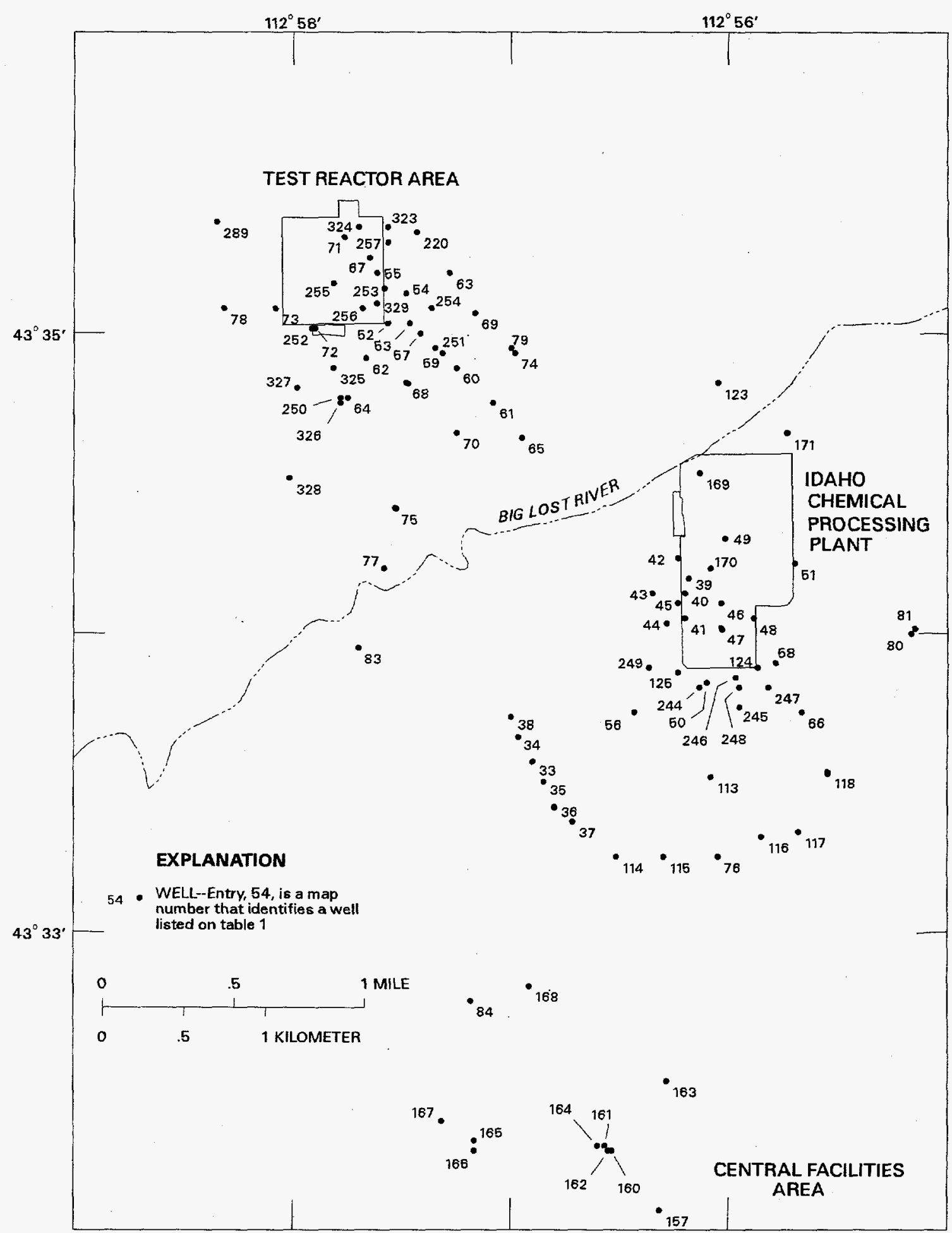

Figure 3. Locations of wells at and near the Idaho Chemical Processing Plant, Test Reactor Area, and Central Facilities Area for which stratigraphic data are available. 


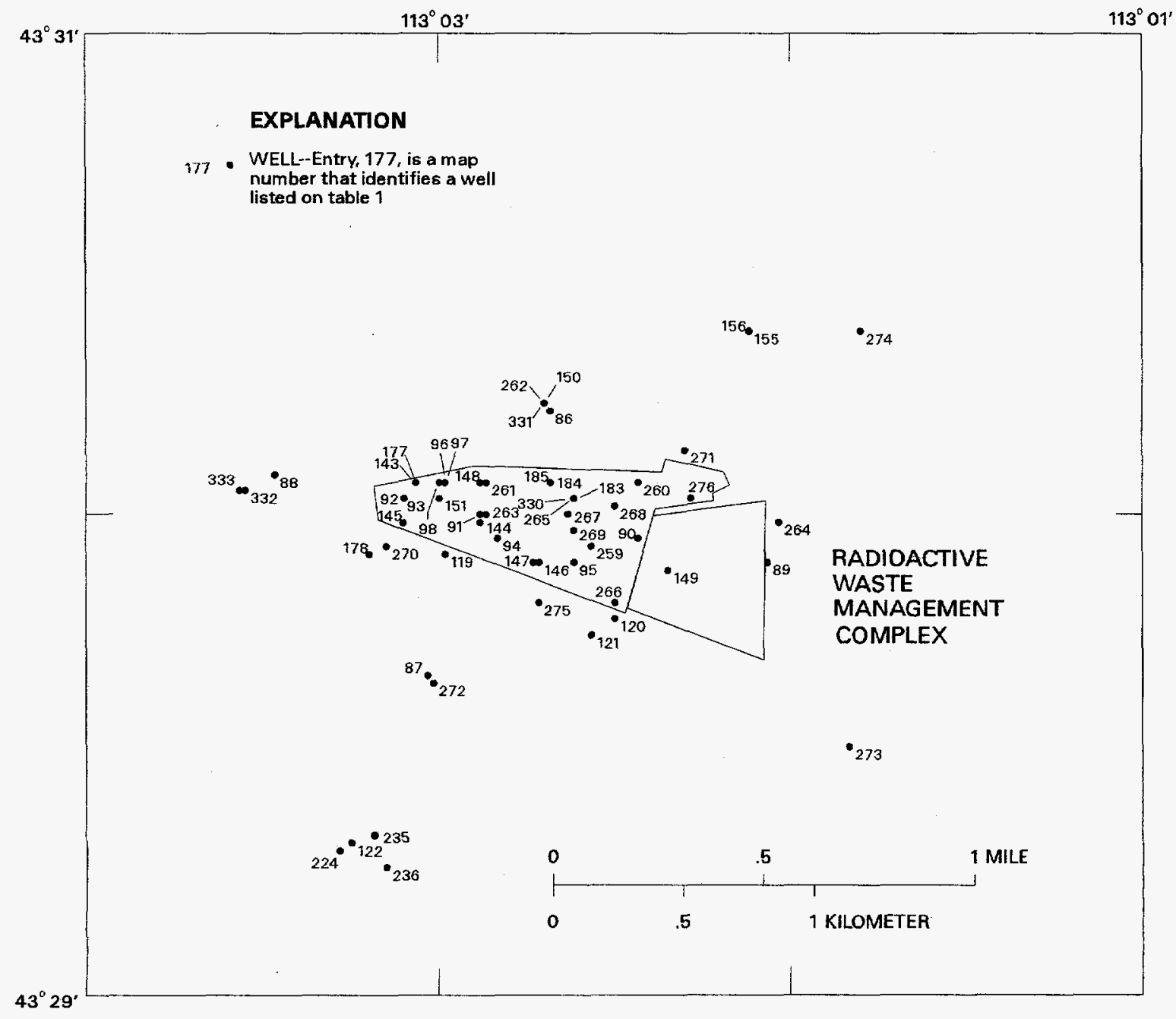

Figure 4. Locations of wells at and near the Radioactive Waste Management Complex for which stratigraphic data are available. 


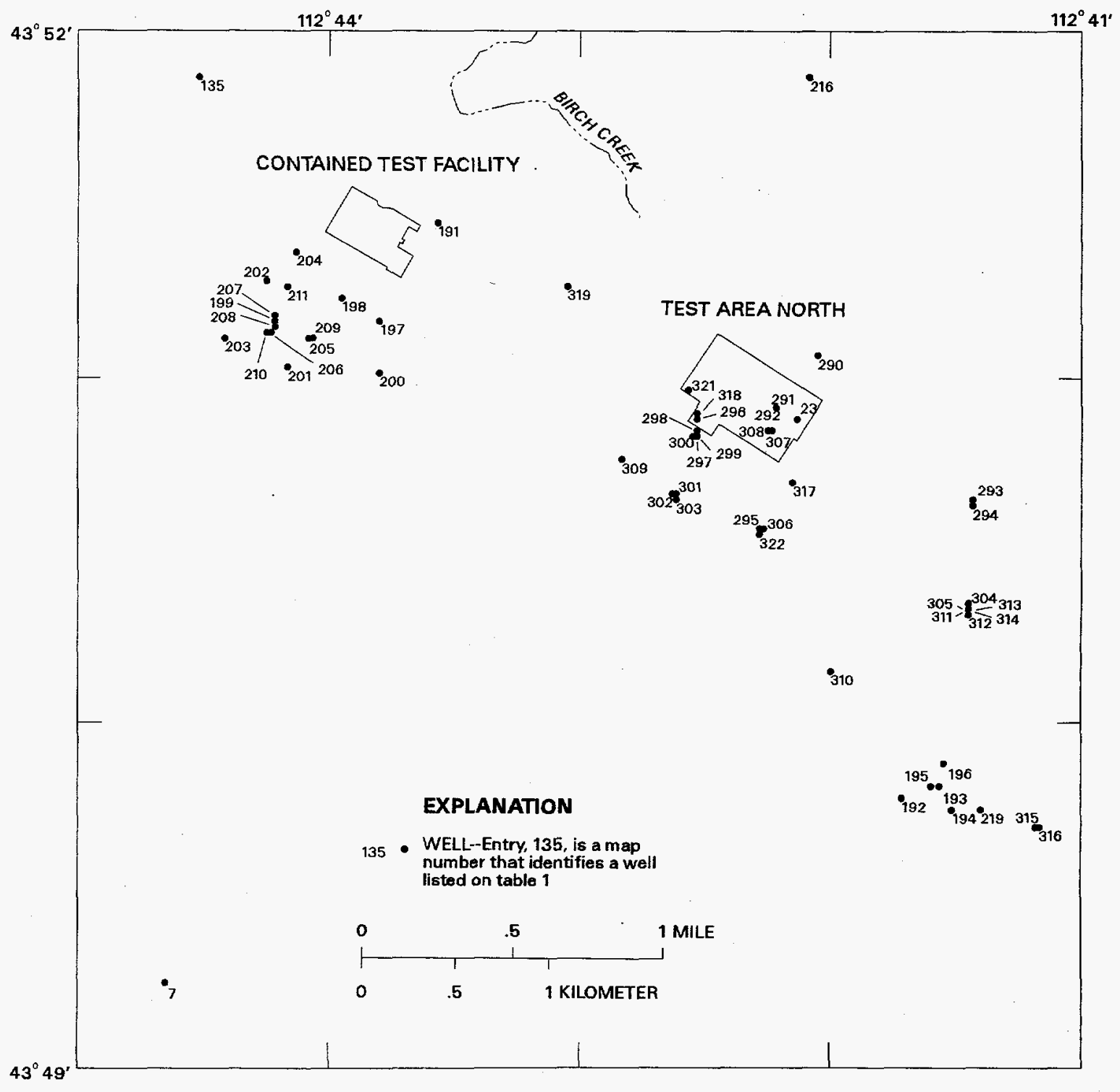

Figure 5. Locations of wells at and near the Contained Test Facility and Test Area North for which stratigraphic data are available. 
Because most wells are completed in the unsaturated zone and uppermost part of the aquifer, stratigraphic data for the lowermost part of the aquifer are limited. The reader is referred to Anderson and others (1996a) for detailed stratigraphic data from wells at and near the INEL that form the basis of this report.

\section{Approach}

Several types of data were used to identify and correlate stratigraphic units underlying the INEL and adjacent areas. Volcanic and sedimentary units were identified from outcrops and cores selectively evaluated for paleomagnetic inclination and polarity, potassium-argon (K-Ar) and argon-argon $\left({ }^{40} \mathrm{Ar} /{ }^{39} \mathrm{Ar}\right)$ geologic ages, petrographic characteristics, and major-oxide and trace-element chemical composition. Stratigraphic units were correlated using these data and naturalgamma logs, which respond to potassium contents of generally less than 1 percent in basalt to more than 4 percent in rhyolite. The distribution and characteristics of basalt, sediment, andesite, and rhyolite outcrops are described by Kuntz and others (1994). The cores and sources of data used to identify stratigraphic units underlying the area are shown in figure 6 and summarized in table 2 (located at the end of this report). The method for correlating stratigraphic units using cores and natural-gamma logs is described by Anderson and Bartholomay (1995). Stratigraphic relations were determined using numerous outcrops and 26 continuous cores and 328 natural-gamma logs obtained from the wells shown in figures 2-5 and listed in table 1. Natural-gamma logs for many of these wells are available in a report by Bartholomay (1990). These and all other logs are on file at the INEL project office of the USGS. Cores are available for inspection at the INEL Lithologic Core Storage Library (Davis and others, 1997).

Upper and lower boundaries of each composite stratigraphic unit were selected to show the main stratigraphic and structural features underlying the INEL and adjacent areas. Selection of upper and lower boundaries of composite stratigraphic units was influenced by local and regional geologic considerations. Local considerations included the need for boundaries that show the relation of composite units with respect to the geologic ages and distributions of widespread stratigraphic units, clusters of volcanic vents, and interpreted structural features at and near the INEL. Regional considerations included the need for boundaries that show the relation of composite units with respect to previously described geologic formations at and near springs where the aquifer discharges to the Snake River in southern Idaho. Boundaries of composite stratigraphic units include the land surface, the effective base of the aquifer (table 3, located at the end of this report) and the tops of basalt flow groups BC(1), DE2(1), DE5(1), E(1), FG(1), I(1) LM1(1) LM5(1), M(1), NO(1), P(1), R1(1), and S2(1) (table 4, located at the end of this report). Geologic ages of these and other stratigraphic units are described by Anderson and others (1997); selected ages are shown in table 5 (located at the end of this report). The distribution of volcanic vents associated with these and other volcanic units is shown in figure 7. Structural features, which are attributed to past differential subsidence and uplift (Anderson and others, 1997) are shown in figure 6. Composite stratigraphic units 1 through 7 correlate with the Snake River Group, units 8 through 14 with the Bruneau Formation, and deposits older than unit 14, the effective base of the aquifer, with the Glenns Ferry Formation in southem Idaho (Armstrong and others, 1975; Kimmel, 1982; Whitehead and Lindholm, 1985; Whitehead, 1992; Repenning and others, 1995; Anderson and Bowers, 1995).

\section{Acknowledgments}

Technical assistance and data from numerous geologic investigations were obtained from Duane E. Champion, Marvin A. Lanphere, and Mel A. Kuntz, USGS, Geologic Division. David B. Frederick, State of Idaho, INEL Oversight Program, and Terrence D. Conlon, USGS, Water Resources Division, reviewed the report and provided many helpful suggestions concerning its content and organization. 


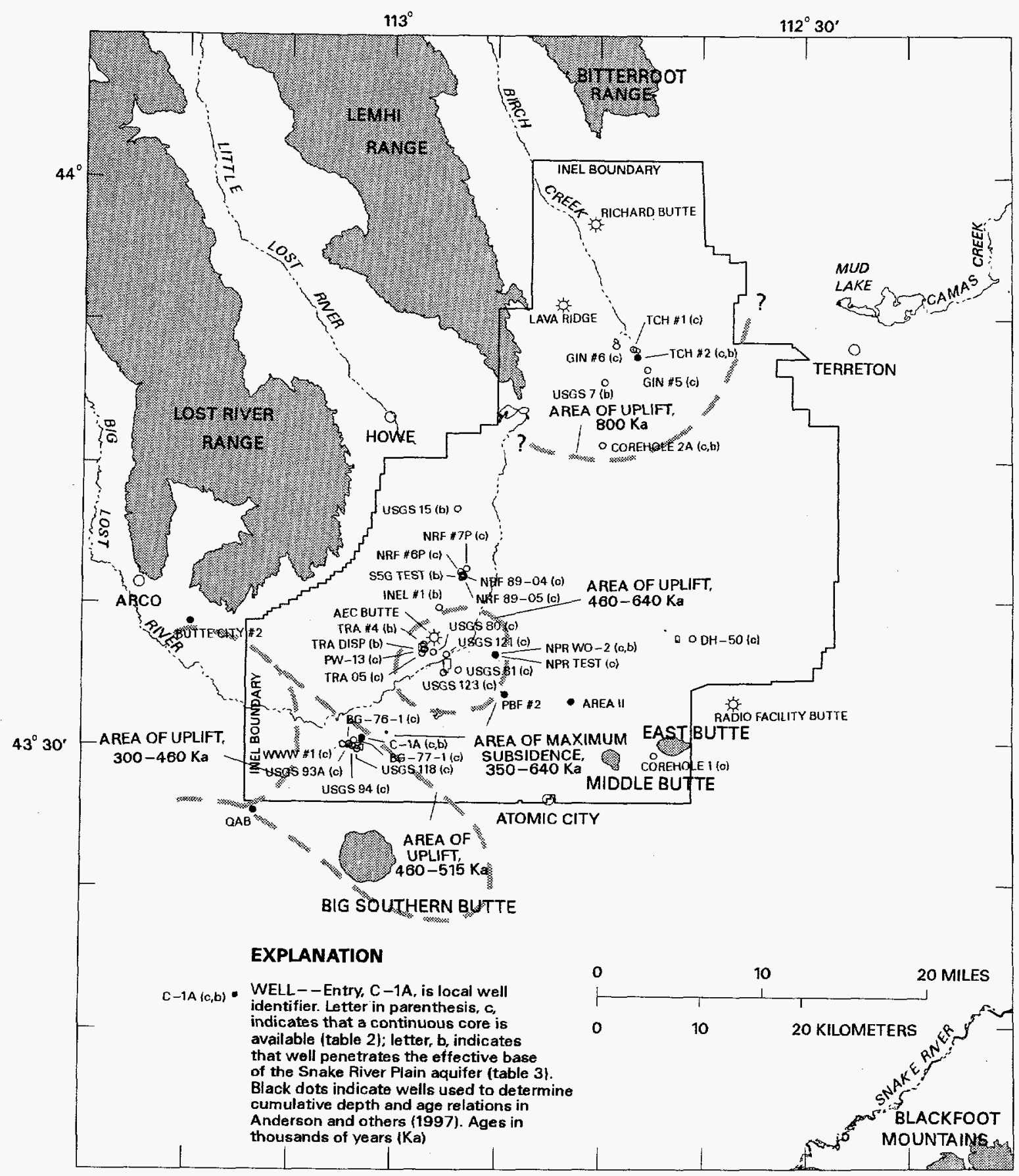

Figure 6. Locations of selected wells and cores used to evaluate geologic ages, accumulation rates, stratigraphy, and structure of basalt-flow groups and sedimentary interbeds in the unsaturated zone and the Snake River Plain aquifer at the Idaho National Engineering Laboratory. 


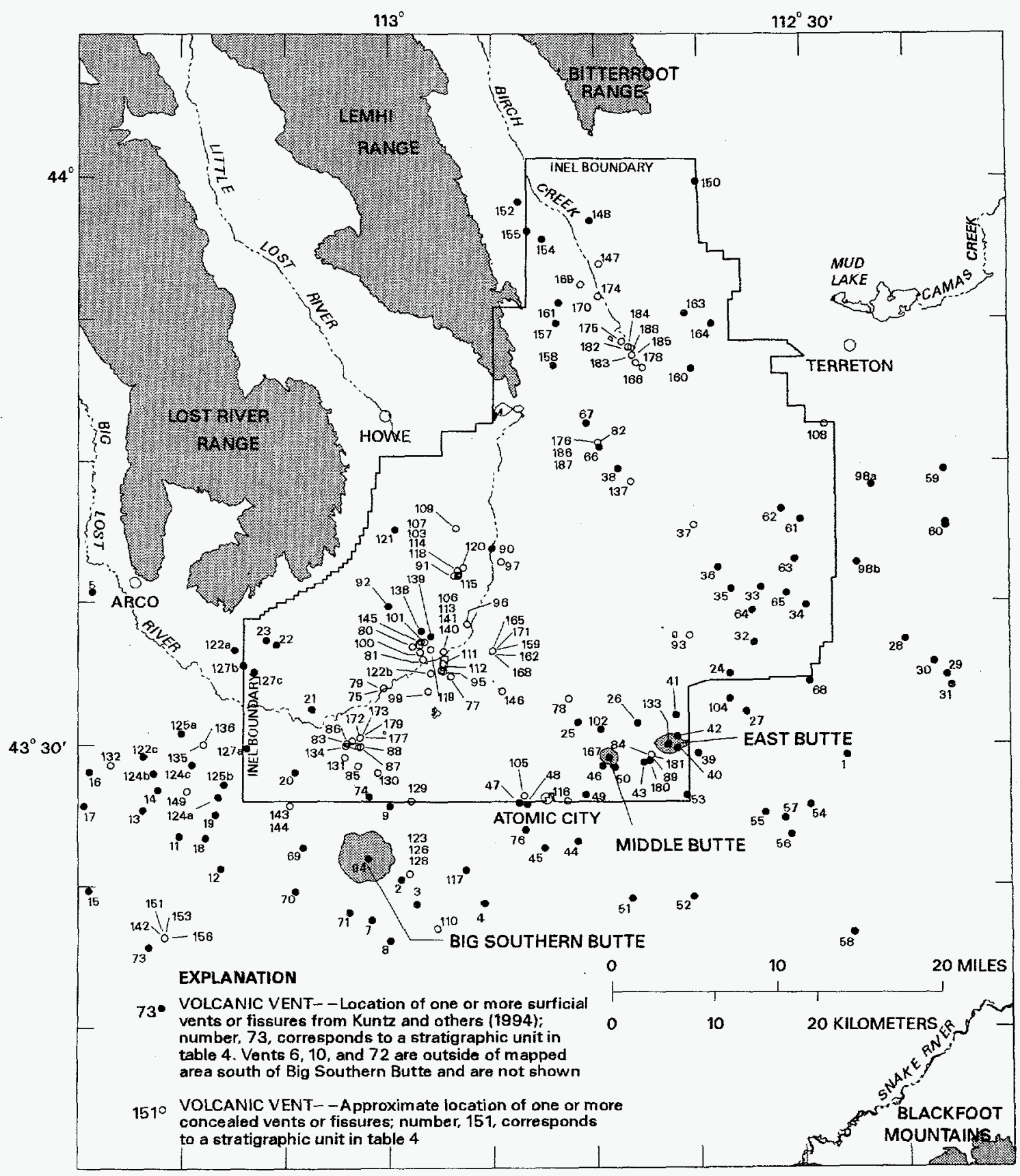

Figure 7. Locations of selected volcanic vents at and near the Idaho National Engineering Laboratory. 


\section{GEOHYDROLOGIC SETTING}

The INEL is on the west-central part of the eastern Snake River Plain, a northeast-trending structural basin about $200 \mathrm{mi}$ long and 50 to $70 \mathrm{mi}$ wide (fig. 1). The INEL is underlain by a sequence of Tertiary and Quaternary volcanic rocks and sedimentary interbeds that is more than $10,000 \mathrm{ft}$ thick (Walker, 1964; Doherty and others, 1979; Whitehead, 1992; Hackett and others, 1994; Smith and others, 1994). The volcanic rocks consist mainly of basaltic lava flows, ash, and cinders in the upper part and rhyolitic ash flows and tuffs in the lower part. In places, especially along the axis of the plain, Quatemary rhyolite domes stand as high as $2,000 \mathrm{ft}$ above the surface of the plain. The basaltic rocks, which are interbedded with andesite and sediment, underlie the plain to depths ranging from about 2,200 to $3,800 \mathrm{ft}$ in the southwestern part of the INEL. Volcanic vents for the basalt, andesite, and rhyolite (fig. 7 ) are concentrated in a volcanic zone along the axis of the plain and in volcanic rift zones that trend perpendicular to the axis of the plain (Kuntz and others, 1992; Kuntz and others, 1994).

The INEL is underlain by hundreds of basalt flows, basalt-flow groups, and sedimentary interbeds. Basalt flows make up about 85 percent of the volume of deposits in the unsaturated zone and aquifer, local deposits of sediment make up most of the remaining volume. A basalt flow is a solidified body of rock formed by a lateral, surficial outpouring of molten lava from a vent or fissure (Bates and Jackson, 1980). A basalt-flow group consists of one or more distinct basalt flows deposited during a single eruptive event (Kuntz and others, 1980). All basalt flows of a group erupted from the same volcanic vent or vents and have similar ages, paleomagnetic properties, potassium contents, and natural-gamma emissions (Anderson and Bartholomay, 1995). The basalt flows, which locally are altered (Fromm and others, 1994), consist mainly of medium- to darkgray vesicular to dense olivine basalt and are as much as $100 \mathrm{ft}$ thick. Sedimentary interbeds, which are most abundant between flow groups, accumulated on the ancestral land surface for hundreds to hundreds of thousands of years during periods of volcanic quiescence. Sedimentary interbeds are as much as $50 \mathrm{ft}$ thick and consist of well- to poorly-sorted deposits of clay, silt, sand, and gravel of fluvial, lacustrine, and eolian origin. In places the interbeds contain cinders and basalt rubble.

The basalt and sediment underlying the INEL, where saturated, form the Snake River Plain aquifer. Depth to water at the INEL ranges from about $200 \mathrm{ft}$ below land surface in the northern part to about $900 \mathrm{ft}$ in the southern part (Ott and others, 1992); the general direction of groundwater flow is northeast to southwest. The effective base of the aquifer at the INEL generally coincides with the top of a thick and widespread layer of clay, silt, sand, and altered basalt that is older than about 1.8 million years (table 5 ) and equivalent in age to the Glenns Ferry Formation (Anderson and Bowers, 1995). The effective base of the aquifer ranges in depth from 815 to $1,710 \mathrm{ft}$ below land surface in the western half of the INEL (table 3, located at the end of this report); depth to the base may be greater than $1,900 \mathrm{ft}$ in the eastern half of the INEL. The saturated thickness of the aquifer ranges from $445 \mathrm{ft}$ near the TRA to 1,200 ft east of the ICPP (table 3); saturated thickness may be greater than $1,200 \mathrm{ft}$ in the eastern half of the INEL. Hydraulic properties of the aquifer differ considerably from place to place depending on saturated thickness and the characteristics of the basalt and sediment. In places, the basalt and sediment in the uppermost part of the aquifer yield thousands of gallons per minute of water to wells, with negligible drawdown (Ackerman, 1991). Hydraulic data for the basalt, sediment, ash, and tuff underlying the aquifer are sparse, but data from well INEL \#1 (fig. 2; tables 1 and 3 ) indicate that these deposits are relatively impermeable compared with those in the aquifer (Mann, 1986). Localized zones of perched ground water, which are attributed mainly to infiltration of water from unlined percolation ponds and recharge from the Big Lost River, are present in basalt and sediment overlying the regional aquifer (Cecil and others, 1991). 


\section{STRATIGRAPHY}

Stratigraphic units at and near the INEL consist of basalt-flow groups, surficial sediment/ sedimentary interbeds, andesite-flow groups, and thyolite domes. About 100 basalt-flow groups, 1 andesite-flow group, 4 rhyolite domes, and surficial sediment cover the INEL and adjacent areas (Kuntz and others, 1994). Stratigraphic units identified in 333 wells completed in the unsaturated zone and the Snake River Plain aquifer include 121 basalt-flow groups, 102 sedimentary interbeds, 6 andesite-flow groups, and 1 thyolite dome (Anderson and others, 1996a); these units exclude 57 basalt-flow groups, 3 rhyolite domes, and 1 sediment layer that were identified by Kuntz and others (1994) at the land surface but which are not present in wells. Outcrops and subsurface deposits comprise 292 stratigraphic units, each of which was assigned an informal alphanumeric name, from $\mathrm{Au}(1)$ to $\mathrm{S} 5(1)$, that corresponds to its age relative to other units (table 4). The youngest of the 230 units identified in wells was designated $\mathrm{Al}(1)$ and the oldest was designated S5(1) (table 4). Basalt, andesite, and rhyolite erupted from numerous volcanic vents (fig. 7), many of which are now concealed by younger deposits (Anderson and Lewis, 1989; Anderson, 1991; Kuntz and others, 1994; Anderson and Bowers, 1995). Locations of concealed vents were approximated on the basis of the greatest thickness of each correlative volcanic unit in wells.

In this report, stratigraphic units and names were modified from and supersede those described in earlier reports about the RWMC (Anderson and Lewis, 1989), the ICPP and TRA (Anderson, 1991), and TAN (Anderson and Bowers, 1995). A numerical suffix was added to all names to describe the relative age of units having the same letter name; for the same letter name, the larger number is the older unit (table 4). For example, the earlier names of basalt-flow groups B, C, and $F$ at the RWMC and $\mathrm{LM}(\mathrm{E}), \mathrm{LM}(\mathrm{W})$, and $\mathrm{P}$ at TAN were changed to $\mathrm{B}(1), \mathrm{C}(1), \mathrm{F}(1), \mathrm{LM} 6(2)$, LM6(3), and $P(1)$, respectively, to show that each letter name corresponds with one or more units. The earlier name of the youngest flow group at the RWMC, A, was changed to $\mathrm{Al}(9)$ to show its age relative to the youngest unit at the INEL, $\mathrm{Au}(1)$. Many units, such as basalt-flow groups DE3-4(E) and DE3-4(W) at the ICPP and TRA, were subdivided and renamed on the basis of new data; these flow groups are now referred to as DE3-4(1), DE3-4(2), DE3-4(3), and DE3-4(4), respectively. The earlier names of sedimentary interbeds, such as C-D at the RWMC and P-Q at TAN, also were changed to correspond with the names used for volcanic units of the same or similar age; these interbeds are now referred to as $C D(1)$ and $P Q(1)$. Differences between this stratigraphic framework and earlier frameworks are least for units at TAN and greatest for units at the ICPP and TRA.

Determining the geologic ages of basalt flows at the INEL is difficult because all the flows are extremely young and many are altered in and below the lowermost part of the aquifer. The most reliable measured ages generally are obtained from outcrops, the unsaturated zone, and the uppermost part of the aquifer (table 5). Ages of selected basalt, andesite, and rhyolite outcrops and cores were measured using various methods (Champion and others, 1988; Forman and others, 1993; Lanphere and others, 1993; Forman and others, 1994; Kuntz and others, 1994; Lanphere and others, 1994; this report, tables 2 and 5). Ages of selected basalt-flow groups also were estimated using linear accumulation rates in selected wells to evaluate measured ages of flow groups with respect to their stratigraphic position in the subsurface (Anderson and others, 1997; this report, table 5) Measured ages of surficial volcanic units range from about 5.2 thousand to 1.40 million years (Kuntz and others, 1994). Measured ages of basalt-flow groups $\mathrm{Al}(9)$ through $\mathrm{S5}(1)$ in the unsaturated zone and aquifer range from about 100 thousand to 2.56 million years (table 5). Estimated stratigraphic ages of flow groups $\mathrm{Al}(9)$ through S5(1) range from about 100 thousand to 1.71 million years (table 5). Agreement between measured and estimated ages ranges from good for flow groups $\mathrm{Al}(9)$ through LM6(3) and $\mathrm{R} 1$ (1) to poor for flow groups S1(1) through S5(1) (table 5). Flow groups $S 1(1)$ through $S 5(1)$, which were identified only in the subsurface at and near TAN, either yielded unreliable K-Ar ages (Anderson and Bowers, 1995) or are incorrectly assigned to 
the lowermost part of the aquifer (Anderson and others, 1996a). If flow groups S1(1) through S5(1) are in the lowermost part of the aquifer as interpreted in table 4, their ages must be less than about 1.8 million years. This conclusion is based on a flow group, TU(1), situated just below the effective base of the aquifer near the ICPP, that yielded $\mathrm{a}^{40} \mathrm{Ar} /{ }^{39} \mathrm{Ar}$ and paleomagnetic age of about 1.86 million years (M.A. Lanphere, USGS, written commun., 1995; this report, table 5). In general, ${ }^{40} \mathrm{Ar} /{ }^{39} \mathrm{Ar}$ ages are more reliable than K-Ar ages (Berggren and others, 1995), and all measured ages are improved by considering the paleomagnetic polarities and inclinations of their corresponding basalt flows.

Geologic ages of stratigraphic units are constrained by paleomagnetic polarity and inclination data obtained from 25 cores (table 2). Polarity, age, and stratigraphic data from these and three new cores (table 6, located at the back of this report) are consistent with two paleomagnetic chrons, the Brunhes Normal Polarity Chron and the Matuyama Reversed Polarity Chron, and two paleomagnetic subchrons, the Big Lost Reversed Polarity Subchron and the Olduvai Normal Polarity Subchron (Champion and others, 1988; Berggren and others, 1995). Polarity and stratigraphic data also suggest that three additional paleomagnetic subchrons are present in these cores, the Emperor Reversed Polarity Subchron, the Jaramillo Normal Polarity Subchron, and the Cobb Mountain Normal Polarity Subchron (table 6); however, preliminary measured ages of these polarity subchrons are uncertain (D.E. Champion and M.A. Lanphere, USGS, written commun., 1989-95). Stratigraphic units younger than about 780 thousand years generally have normal paleomagnetic polarity and are assigned to the Brunhes Normal Polarity Chron (tables 5 and 6). Basaltflow group $\mathrm{F}(1)$, a unique stratigraphic marker in the lowermost part of the unsaturated zone and uppermost part of the aquifer in the southern part of the INEL, has reversed polarity, an age of about 550 thousand years in well BG-77-1, and is assigned to the Big Lost Reversed Polarity Subchron (Champion and others, 1988, 1996). Units older than about 780 thousand years generally have reversed paleomagnetic polarity and are assigned to the Matuyama Reversed Polarity
Chron (tables 5 and 6). Flow group TU(1), a unique stratigraphic marker at the effective base of the aquifer near the ICPP, TAN, and ANL-W, has normal polarity, an age of about 1.86 million years in well NPR WO-2, and is assigned to the Olduvai Normal Polarity Subchron (M.A. Lanphere, USGS, written commun., 1995; this report, table 6). Paleomagnetic inclination of basalt-flow groups generally ranges from 40 to 80 degrees and is similar for all flows of each group. In well USGS 80 , for example, inclination ranges from $53.9 \pm 1.9$ degrees for flow group I(1) to 76.0 \pm 2.4 degrees for flow group DE5-6(3) (Lanphere and others, 1993). In well TCH \#1, inclination ranges from $-50.2 \pm 3.9$ degrees for flow group R1(1) to $-71.5 \pm 0.6$ degrees for flow groups $\mathrm{O}(1), \mathrm{P}(1)$, and $\mathrm{Q}(1)$ (Lanphere and others, 1994).

Most of the INEL is covered by basalt and sediment older than basalt-flow group A1(9) (table 4), a group that erupted from Quaking Aspen Butte (fig. 7, vent 12) about 100 thousand years ago (Kuntz and others, 1994; this report, table 5). Collectively, basalt-flow groups and sedimentary interbeds $\mathrm{AB}(1)$ through $\mathrm{L}(2)$ (table 4) range in age from about 200 to 800 thousand years, are widespread, and make up the unsaturated zone and uppermost part of the aquifer in most parts of the INEL. Basalt-flow groups and sedimentary interbeds LM(1) through S5(1), which range in age from about 800 thousand to 1.8 million years, make up the unsaturated zone and aquifer at and near the CTF and TAN (fig. 1) and the lowermost part of the aquifer elsewhere at the INEL (Anderson and Bowers, 1995). Basalt-flow groups and sedimentary interbeds $A B(1)$ through S5(1) make up a stratigraphic section that is characterized by horizontal to inclined layers (Anderson and Lewis, 1989; Anderson, 1991; Anderson and Bowers, 1995). Each basalt-flow group in the section was deposited during an eruptive event that lasted no more than a few hundred years (Kuntz and others, 1980). The average length of time between these eruptions was about 10 to 20 thousand years, sufficiently long to accumulate thick layers of sediment in many areas. In places, the section is characterized by missing intervals of basalt and sediment. These interruptions in accumulation, which are referred to as hiatuses 
(Anderson and others, 1997), generally represent no more than a few tens of thousands of years at any one place. However, prolonged hiatuses, which are defined as missing intervals of basalt representing periods of at least 200 thousand years, characterize the land surface in most parts of the INEL and nearby areas above basalt-flow groups $\mathrm{AB}(2)$ through $\mathrm{AB}(58)$ (table 4) and occur within the stratigraphic section at and near the ICPP, TRA, RWMC, CTF, and TAN (fig. 1). The prolonged hiatus at the land surface has resulted from significantly reduced volcanism during the past 200 thousand years; for millions of years before the past 200 thousand years, the frequency and volume of eruptions were much greater (Kuntz and others, 1994; Anderson and Bowers, 1995). Prolonged hiatuses at and near the ICPP, TRA, RWMC, CTF, and TAN are attributed to differential subsidence and uplift (fig. 6) during the past 1.8 million years (Smith and others, 1994; Anderson and others, 1997). Uplift, which last occurred about 300 to 800 thousand years ago (fig. 6), probably resulted from the emplacement of laccoliths and domes within or beneath the subsiding stratigraphic section (Anderson and others, 1997); alternatively, some of these areas can be interpreted as areas of past differential subsidence or faulting.

\section{Composite Stratigraphic Units}

Fourteen composite stratigraphic units, each made up of 5 to 90 stratigraphic units of similar age (table 4), are used to describe the stratigraphy of the unsaturated zone and the Snake River Plain aquifer at and near the INEL. Upper and lower boundaries of each composite unit were selected to show the main stratigraphic and structural features underlying the area. Composite unit 1, the youngest unit, is made up of 78 basalt-flow groups and 12 sedimentary interbeds between the tops of sedimentary interbed $\mathrm{Au}(1)$ and basaltflow group BC(1). Composite unit 14, the oldest unit, is made up of 4 basalt-flow groups and 1 sedimentary interbed between the top of basaltflow group S2(1) and the effective base of the aquifer. Composite units 2 through 13 collectively are made up of 96 basalt-flow groups, 90 sedimentary interbeds, 6 andesite-flow groups, and 4 rhyolite domes. Composite units 2 through 13 have upper and lower boundaries that coincide with the tops of basalt-flow groups $\mathrm{BC}(1)$, DE2(1), DE5(1), E(1), FG(1), I(1), LM1(1) LM5(1), M(1), NO(1), P(1), R(1), and S2(1) (table 4). All composite units locally include some, most, or all of the stratigraphic units assigned to each on table 4 . The decrease in the number of stratigraphic units assigned to each successively older composite unit (table 4 ) is attributed partly to larger and less-frequent volcanic eruptions during the accumulation of these units and partly to the limited distribution of available cores used to identify stratigraphic units at greater depths in the subsurface (fig. 6; table 2).

The distributions, altitudes, and thicknesses of composite stratigraphic units 1 through 14 are shown in figures 8 through 30 and are summarized in table 7 (located at the end of this report). The average thickness of composite units ranges from $62 \mathrm{ft}$ for unit 1 to $266 \mathrm{ft}$ for unit 7; the average thickness of units 8 through 14 , which are combined in figures 29 and 30 because of insufficient areal distribution of data for individual units, is $832 \mathrm{ft}$ in six representative wells. Average sediment content of composite units ranges from 5 percent for unit 5 to 47 percent for unit 1. Topographic relief on the top of composite units, disregarding the relief of individual volcanic vents and rhyolite domes, ranges from $469 \mathrm{ft}$ for unit 3 to $1,171 \mathrm{ft}$ for units 8 through 14 . Water levels in the aquifer in 1996 coincided with composite units 4 and 5 throughout most of the INEL and adjacent areas; water levels coincided with unit 12 at and near the CTF and TAN.

Composite stratigraphic unit 1-Composite stratigraphic unit 1 (figs. 8-17) includes mainly surficial sediment in the central parts of the INEL and young basalt flows east through southwest of the INEL (Kuntz and others, 1994; Anderson and others, 1996b); this unit includes 78 basalt-flow groups and 12 sedimentary interbeds (table 7). Unit 1 is fully penetrated by 326 of the 333 wells evaluated by Anderson and others (1996a) at and near the INEL (fig. 2), including all 96 wells at the ICPP, TRA, and CFA (fig. 3), 54 of the 58 wells at the RWMC (fig. 4), and all 58 wells at the CTF and TAN (fig. 5). In the wells where it is 
present, the top of unit 1 , which coincides with the land surface, ranges in altitude from $5,375 \mathrm{ft}$ above sea level in well USGS 13 to $4,772 \mathrm{ft}$ in well USGS 28 . The base of the unit ranges in altitude from $5,362 \mathrm{ft}$ in well USGS 13 to $4,721 \mathrm{ft}$ in well GIN \#6. Thickness of unit 1 ranges from 0 to $284 \mathrm{ft}$, averages $62 \mathrm{ft}$ in the 326 wells that fully penetrate its base, and is greatest in well USGS 124. Sediment content of unit 1 ranges from none in wells USGS 16 and NPR WO-2 to 100 percent in many wells; content averages 47 percent in the 326 wells that fully penetrate its base. The number of sedimentary interbeds in the unit at any one place ranges from none in wells USGS 16 and NPR WO-2 to five in well Butte City \#2.

Composite unit 1 is made up of stratigraphic units $\mathrm{Au}(1)$ through B-BC(4) (table 4); geologic ages of these units range from about 5 to 250 thousand years (Kuntz and others, 1994; Anderson and others, 1997). Basalt-flow groups in composite unit 1 erupted from vents 1 through 78 (fig. 7), located mainly in the eastern through southwestern parts of the area.

\section{Composite stratigraphic unit 2.-Composite} stratigraphic unit 2 (figs. 8-15 and 17-19) includes 18 basalt-flow groups, 13 sedimentary interbeds, and 1 rhyolite dome, Big Southem Butte (fig. 8, table 7). The top of this composite unit is penetrated by 234 of the 333 wells evaluated by Anderson and others (1996a) at and near the INEL (fig. 2), including 93 of the 96 wells at the ICPP, TRA, and CFA (fig. 3), 54 of the 58 wells at the RWMC (fig. 4), and 1 of the 58 wells at the CTF and TAN (fig. 5). The base of this unit is penetrated by 178 wells at and near the INEL, including 75 wells at the ICPP, TRA and CFA, 22 wells at the RWMC, and 1 well at the CTF and TAN. In the wells where it is present, the top of composite unit 2 ranges in altitude from $5,299 \mathrm{ft}$ above sea level in well Corehole 1 to $4,732 \mathrm{ft}$ in well ANP \#9. The base of the unit ranges in altitude from $5,175 \mathrm{ft}$ in well Weaver and Lowe to 4,659 $\mathrm{ft}$ in the EFS well. Thickness of unit 2 ranges from 0 to $321 \mathrm{ft}$, averages $109 \mathrm{ft}$ in the 178 wells that fully penetrate its base, and is greatest in well Corehole 1. Sediment content of unit 2 ranges from none to 100 percent in many wells and averages 11 percent in the 178 wells that fully penetrate its base. The number of sedimentary interbeds in the unit at any one place ranges from none in many wells to five in well USGS 59. Composite unit 2 is made up of stratigraphic units $\mathrm{BC}(1)$ through DE1-2(3) (table 4); geologic ages of these units range from about 250 to 350 thousand years (Kuntz and others, 1994; Anderson and others, 1997). Basalt-flow groups in composite unit 2 erupted from volcanic vents 79 through 97 (fig. 7), located mainly in the southern part of the area; Big Southern Butte (fig. 8), stratigraphic unit DE1(4), erupted from vent 94.

\section{Composite stratigraphic unit 3-Composite} stratigraphic unit 3 (figs. 8-15 and 19-21) includes 17 basalt-flow groups, 17 sedimentary interbeds, and 1 andesite-flow group (table 7). The top of this composite unit is penetrated by 164 of the 333 wells evaluated by Anderson and others (1996a) at and near the INEL (fig. 2), including 78 of the 96 wells at the ICPP, TRA, and CFA (fig. 3), none of the 58 wells at the RWMC (fig. 4), and 1 of the 58 wells at the CTF and TAN (fig. 5 ). The base of this unit is penetrated by 143 wells at and near the INEL, including 66 wells at the ICPP, TRA, and CFA, none of the wells at the RWMC, and 1 well at the CTF and TAN. In the wells where it is present, the top of composite unit 3 ranges in altitude from $5,128 \mathrm{ft}$ above sea level in well Butte City \#2 to 4,659 ft in the EFS well. The base of the unit ranges in altitude from $5,048 \mathrm{ft}$ in well Butte City \#2 to 4,465 ft in well USGS 17. Thickness of unit 3 ranges from 0 to $305 \mathrm{ft}$, averages $164 \mathrm{ft}$ in the 143 wells that penetrate its base, and is greatest in well Highway \#2. Sediment content of unit 3 ranges from none to 100 percent in many wells and averages 15 percent in the 143 wells that fully penetrate its base. The number of sedimentary interbeds in the unit at any one place ranges from none in many wells to seven in wells Barney North, Site 14, and DH1B, located east through southwest of the CTF and TAN. Composite unit 3 is made up of stratigraphic units DE2(1) through DE4-5(5) (table 4); geologic ages of these units range from about 350 to 440 thousand years (Kuntz and others, 1994; Anderson and others, 1997). Basalt-flow groups in composite unit 3 erupted from volcanic vents $98 \mathrm{a}$ and $98 \mathrm{~b}$ through 115 (fig. 7), located mainly in the eastem and southem parts of the area; andesite-flow group DE4(2), which could be 
related to the older flows of Cedar Butte (fig. 8), erupted from vent 110 .

Composite stratigraphic unit 4.-Composite stratigraphic unit 4 (figs. 8-15 and 21-23) includes 9 basalt-flow groups, 11 sedimentary interbeds, and 4 andesite-flow groups (table 7); the youngest andesite flow group erupted from Cedar Butte (fig. 8). The top of this composite unit is penetrated by 172 of the 333 wells evaluated by Anderson and others (1996a) at and near the INEL (fig. 2), including 66 of the 96 wells at the ICPP, TRA, and CFA (fig. 3), 17 of the 58 wells at the RWMC (fig. 4), and none of the 58 wells at the CTF and TAN (fig. 5). The base of this unit is penetrated by 146 wells at and near the INEL, including 60 wells at the ICPP, TRA, and CFA, 17 wells at the RWMC, and none of the wells at the CTF and TAN. In the wells where it is present, the top of composite unit 4 ranges in altitude from $5,362 \mathrm{ft}$ above sea level in well USGS 13 to $4,465 \mathrm{ft}$ in well USGS 17 . The base of the unit ranges in altitude from $5,257 \mathrm{ft}$ in well Water table to $4,272 \mathrm{ft}$ in well S5G Test. Thickness of unit 4 ranges from 0 to $482 \mathrm{ft}$, averages $138 \mathrm{ft}$ in the 146 wells that penetrate its base, and is greatest in well USGS 124. Sediment content of unit 4 ranges from none to 100 percent in many wells and averages 11 percent in the 146 wells that fully penetrate its base. The number of sedimentary interbeds in the unit at any one place ranges from none in many wells to five in well DH2A southwest of the CTF and TAN. Composite unit 4 is made up of stratigraphic units DE5(1) through DE9(1) (table 4); geologic ages of these units range from about 440 to 515 thousand years (Kuntz and others, 1994; Anderson and others, 1997). Basalt-flow groups in composite unit 4 erupted from volcanic vents 116 through 128 (fig. 7), located mainly in the southwestern part of the area. Cedar Butte (fig. 8), stratigraphic unit DE5-6(1), erupted from vent 117; andesite-flow groups DE6(2), DE7(2), and DE8(2), which could be related to the younger flows of Cedar Butte, erupted from vents 123 , 126 , and 128 , respectively.

Composite stratigraphic unit 5-Composite stratigraphic unit 5 (figs. 8-15 and 23-25) includes 3 basalt-flow groups and 6 sedimentary interbeds (table 7). The top of this composite unit is penetrated by 143 of the 333 wells evaluated by Anderson and others (1996a) at and near the INEL (fig. 2), including 55 of the 96 wells at the ICPP, TRA, and CFA (fig. 3), 22 of the 58 wells at the RWMC (fig. 4), and none of the 58 wells at the CTF and TAN (fig. 5). The base of this unit is penetrated by 114 wells at and near the INEL, including 44 wells at the ICPP, TRA, and CFA, 20 wells at the RWMC, and none of the wells at the CTF and TAN. In the wells where it is present, the top of composite unit 5 ranges in altitude from $5,257 \mathrm{ft}$ above sea level in well Water table to $4,272 \mathrm{ft}$ in well S5G Test. The base of the unit ranges in altitude from $5,059 \mathrm{ft}$ in well Water table to 4,093 ft in well EBR-1. Thickness of unit 5 ranges from 0 to $329 \mathrm{ft}$, averages $125 \mathrm{ft}$ in the 114 wells that penetrate its base, and is greatest in well USGS 120. Sediment content of unit 5 ranges from none in many wells to 100 percent in wells Weaver and Lowe, USGS 15, and Cope; content averages 5 percent in the 114 wells that penetrate its base. The number of sedimentary interbeds in the unit at any one place ranges from none in many wells to four in well USGS 15 north of the NRF. Composite unit 5 is made up of stratigraphic units $\mathrm{E}(1)$ through $\mathrm{F}(2)$ (table 4); geologic ages of these units range from about 515 to 580 thousand years (Kuntz and others, 1994; Anderson and others, 1997). Basalt-flow groups in composite unit 5 erupted from volcanic vents 129 , 130, and 131 (fig. 7), located between the RWMC and Big Southern Butte (fig. 8).

Composite stratigraphic unit 6.-Composite stratigraphic unit 6 (figs. 8-15 and 25-27) includes 5 basalt-flow groups, 8 sedimentary interbeds, and 1 rhyolite dome, East Butte (fig. 8; table 7). The top of this composite unit is penetrated by 118 of the 333 wells evaluated by Anderson and others (1996a) at and near the INEL (fig. 2), including 46 of the 96 wells at the ICPP, TRA, and CFA (fig. 3), 20 of the 58 wells at the RWMC (fig. 4), and none of the wells at the CTF and TAN (fig. 5). The base of this unit is penetrated by 68 wells at and near the INEL, including 35 wells at the ICPP, TRA, and CFA, 8 wells at the RWMC, and none of the wells at the CTF and TAN. In the wells where it is present, the top of composite unit 6 ranges in altitude from $5,089 \mathrm{ft}$ above sea level in well USGS 16 to $4,093 \mathrm{ft}$ in 
well EBR-1. The base of the unit ranges in altitude from $4,876 \mathrm{ft}$ in well USGS 16 to $3,939 \mathrm{ft}$ in well EOCR. Thickness of unit 6 ranges from 0 to $347 \mathrm{ft}$, averages $107 \mathrm{ft}$ in the 68 wells that penetrate its base, and is greatest in well Water table. Sediment content of unit 6 ranges from none to 100 percent in many wells and averages 23 percent in the 68 wells that penetrate its base. The number of sedimentary interbeds in the unit at any one place ranges from none in many wells to four in well OW-1 at the RWMC. Composite unit 6 is made up of stratigraphic units FG(1) through $\mathrm{HI}(2)$ (table 4); geologic ages of these units range from about 580 to 650 thousand years (Kuntz and others, 1994; Anderson and others, 1997). Basaltflow groups in composite unit 6 erupted from volcanic vents 132 through 137 (fig. 7), located mainly in the southern and southwestern parts of the area. East Butte (fig. 8), stratigraphic unit FG(2), erupted from vent 133.

Composite stratigraphic unit 7.-Composite stratigraphic unit 7 (figs. 8-15 and 27-29) includes 7 basalt-flow groups and 10 sedimentary interbeds (table 7). The top of this composite unit is penetrated by 70 of the 333 wells evaluated by Anderson and others (1996a) at and near the INEL (fig. 2), including 38 of the 96 wells at the ICPP, TRA, and CFA (fig. 3), 3 of the 58 wells at the RWMC (fig. 4), and none of the wells at the CTF and TAN (fig. 5). The base of this unit is penetrated by 15 wells at and near the INEL, including 2 wells at the ICPP, TRA, and CFA, and none of the wells at the RWMC, CTF, and TAN. In the wells where it is present, the top of composite unit 7 ranges in altitude from $4,876 \mathrm{ft}$ above sea level in well USGS 16 to $3,939 \mathrm{ft}$ in well EOCR. The base of the unit ranges in altitude from $4,592 \mathrm{ft}$ in well USGS 16 to $3,807 \mathrm{ft}$ in well PBF \#2. Thickness of unit 7 ranges from 0 to $409 \mathrm{ft}$, averages $266 \mathrm{ft}$ in the 15 wells that fully penetrate its base, and is greatest in well TRA Disp. Sediment content of unit 7 ranges from none in 4 wells to 59 percent in well INEL \#1; content averages 13 percent in the 15 wells that fully penetrate its base. The number of sedimentary interbeds in the unit at any one place ranges from none in four wells to five in well INEL \#1, between the TRA and NRF. Composite unit 7 is made up of stratigraphic units I(1) through L(2) (table 4); geologic ages of these units range from about 650 to 800 thousand years (Kuntz and others, 1994; Anderson and others, 1997). Basaltflow groups in composite unit 7 erupted from volcanic vents 138 through 144 (fig. 7), located near the ICPP and TRA and southwest of the RWMC.

Composite stratigraphic units 8 through 14 .Composite stratigraphic units 8 through 14 (figs. $8-15,29$, and 30) include 41 basalt-flow groups, 26 sedimentary interbeds, 1 andesite-flow group, and 2 rhyolite domes, Middle Butte and the unnamed dome between Middle Butte and East Butte (fig. 8; table 7). The top of these combined units is penetrated by 86 of the 333 wells evaluated by Anderson and others (1996a) at and near the INEL (fig. 2), including 2 of the 96 wells at the ICPP, TRA, and CFA (fig. 3), 1 of the 58 wells at the RWMC (fig. 4), and all 58 of the wells at the CTF and TAN (fig. 5). The base of these combined units is penetrated by 8 of the 333 wells evaluated by Anderson and others (1996a) at and near the INEL, including 2 wells at the ICPP, TRA, and CFA, 1 well at the RWMC, and 2 wells at the CTF and TAN; two additional wells penetrate the effective base of the aquifer below the base of composite unit 7 where units 8 through 14 are not present. Preliminary core studies indicate that a new deep well, ANL-OBS-AQ-014 (Davis and others, 1997; this report (ANL-014), figs. 8, 14, and 15), also penetrates units 8 through 14 (D.E. Champion, USGS, written commun., 1996). In the 9 wells that fully penetrate units 8 through 14 , the top of the combined units ranges in altitude from 4,978 ft above sea level in well Corehole 1 to $3,807 \mathrm{ft}$ in well PBF \#2. The base of the combined units ranges in altitude from $4,017 \mathrm{ft}$ in well TRA Disp to $3,260 \mathrm{ft}$ in well ANL-014. Thickness of the combined units 8 through 14 in 5 wells mountainward of the Big Lost River, wells USGS 15, S5G Test, INEL \#1, TRA \#4, and TRA Disp, ranges from 0 to $43 \mathrm{ft}$. Thickness of the combined units in other parts of the INEL ranges from $602 \mathrm{ft}$ in well TCH \#2 to $1,007 \mathrm{ft}$ in well $\mathrm{C}-1 \mathrm{~A}$, a range that does not include the greater thickness, at least $1,609 \mathrm{ft}$, of the unnamed rhyolite dome and an underlying andesite-flow group in well Corehole 1. Average thickness of combined units is $832 \mathrm{ft}$ in wells 
TCH \#2, USGS 7, Corehole 2A, NPR WO-2, and ANL-014 that penetrate a representative stratigraphic interval in areas basinward of the Big Lost River. In these wells, sediment content ranges from 4 to 13 percent, averages 7 percent, and is greatest in well C-1A at the RWMC; the number of sedimentary interbeds at any one place ranges from three to eight and is greatest in well NPR WO-2, east of the ICPP. Composite units 8 through 14 are made up of stratigraphic units LM1(1) through S5(1) (table 4); the most likely geologic ages of these units, using a combination of measured and estimated ages, range from about 800 thousand to 1.8 million years (Kuntz and others, 1994; Anderson and others, 1997). Basaltflow groups in composite units 8 through 14 erupted from volcanic vents 145 through 188 (fig. 7), located mainly at and near the ICPP, RWMC, CTF, and TAN. The rhyolite of Middle Butte (fig. 8 ), composite unit 10 and stratigraphic unit $\mathrm{M}(2)$, erupted from vent 167; this age and vent number, which are based on the measured age of an older basalt flow overlying this dome (Kuntz and others, 1994), represent a maximum age for the rhyolite and its concealed vent. The adjacent unnamed rhyolite dome (fig. 8) and the underlying andesite-flow group in well Corehole 1 , composite unit 12 and stratigraphic units $Q R(2)$ and $Q R(3)$, erupted from vents 180 and 181, respectively (fig. 7).

\section{Evaluation of Stratigraphic Interpretations}

Stratigraphic units Au(1) through S5(1) (Anderson and others, 1996a; this report, table 4) and composite stratigraphic units 1 through 14 (figs. 8-30) provide local- to regional-scale stratigraphic frameworks, respectively, for use in hydrologic investigations of the unsaturated zone and the Snake River Plain aquifer at and near the INEL. Stratigraphic relations that make up these frameworks are complex, represent the most reasonable interpretations of the data available in December 1993, and can be evaluated using these data and additional data collected since December 1993. Because stratigraphic relations are complex and core data are limited (fig. 6), some regionalscale relations, mainly those of individual basaltflow groups, are uncertain in some areas. In addition, the stratigraphic method used in this study, a combination of paleomagnetism, geochronology, petrography, chemistry, and naturalgamma logs (Anderson and Bartholomay, 1995) could not resolve the distribution of some localscale stratigraphic features, mainly those of individual basalt flows, beyond adjacent cores (Kuntz and others, 1980; Lanphere and others, 1993; Lanphere and others, 1994). Also, stratigraphic correlations of every scale are dependent on agreement between the diverse types of data used to identify and correlate units in the subsurface. Data for some areas agree (Anderson and Bartholomay, 1995) and for others disagree (Anderson and Bowers, 1995; Smith and others, 1996).

Of the youngest 73 basalt-flow groups identified in outcrops, units $\mathrm{Au}(2)$ through $\mathrm{Au}(5)$, $A 1(2)$ through $A 1(13)$, and $A B(2)$ through $A B(58)$, only 22 were identified in wells. This is due partly to the distribution of flow groups and partly to the distribution of wells from which cores and natural-gamma logs were obtained. Although some young flow groups were locally derived, most erupted from vents east through southwest of the INEL (Kuntz and others, 1994; this report, fig. 7) and did not have sufficient volume to cover the area now occupied by the CTF, TAN, NRF, TRA, ICPP, CFA, and RWMC, where most cores and two thirds of the naturalgamma logs were obtained. Identification and correlation of young flow groups in outlying areas were aided by knowing the distribution of outcrops; however, because cores and wells are sparse in these areas, identification and correlation of many older flow groups are uncertain and may be biased by data collected from the facilities located near the Big Lost River (fig. 6). Positive identifications and correlations, consistent with interpretations in this report, have been made for some older flow groups, such as flow group $F(1)$ (table 6), using cores obtained from wells as many as $11 \mathrm{mi}$ apart (Kuntz and others, 1980; Champion and others, 1988; Lanphere and others, 1993; Lanphere and others, 1994; Champion and others, 1996; Reed and others, 1997); however, additional cores are needed to verify similar interpretations made from natural-gamma logs for older flow groups in outlying areas. If the number 
and distribution of older flow groups are similar to those of young flow groups, there may be as many as 300 additional flow groups, not yet identified, in the unsaturated zone and aquifer in outlying areas.

Correlations made using the data obtained as of December 1993 are best for units at the CTF, TAN, NRF, TRA, ICPP, CFA, and RWMC, where most of these data were obtained, and range from good for units at the RWMC to uncertain for units in the eastern half of the INEL. Uncertain correlations mainly include those of basalt interpreted from natural-gamma logs that exceed the maximum known areal extent of basaltflow groups determined by other methods (Champion and others, 1988; Kuntz and others, 1994; Champion and others, 1996). Data from outcrops and cores suggest that the largest flow groups in the subsurface may extend no more than 10 to $15 \mathrm{mi}$ beyond their vents and cover areas of less than to much less than $300 \mathrm{mi}^{2}$. Basalt-flow groups reported by Anderson and others (1996a) that exceed these dimensions, such as flow group I(2) (fig. 7, vent 139; table 4), probably are aggregate flow groups, referred to as supergroups by Welhan and others (1997) and Wetmore and others (1997), made up of two or more individual flow groups. Although the number and distribution of flow groups are uncertain in some areas, the overall stratigraphic framework is consistent with the distribution of many widespread sedimentary interbeds. The most widespread interbeds, $B$ BC(2), CD(1), DE2-3(1), DE5-6(6), DE9(1), and HI(1) (table 4), are about 230, 285, 355, 470, 500, and 640 thousand years old, respectively (Anderson and others, 1997). These and other interbeds and the surficial sediment, stratigraphic units $\mathrm{Au}(1), \mathrm{Al}(1), \mathrm{AB}(1)$, and $\mathrm{B}(1)$ (table 4), were deposited over large areas during periods of general volcanic quiescence that include the past 200 thousand years.

The stratigraphic framework in the southern part of the INEL also is consistent with newly acquired chemical data from wells NPR Test, USGS 121, and USGS 123 (table 2), located at and near the ICPP (Knobel and others, 1995; Reed and others, 1997), and paleomagnetic data from wells STF-PIE-AQ-01 and ARA-COR-005, located about 7 and $11 \mathrm{mi}$ east of the RWMC, respectively (Champion and others, 1996; Davis and others, 1997). Stratigraphic relations in many parts of this area were interpreted from naturalgamma logs, which respond to time-dependent changes in potassium contents of basalt-flow groups. Previously acquired potassium contents of basalt cores from wells at the RWMC range from about 0.25 percent in flow group $\mathrm{E}(1)$ to about 0.70 percent in flow groups $D(1)$ and $F(1)$ (Anderson and Bartholomay, 1995). Potassium contents of basalt cores from wells NPR Test, USGS 121, and USGS 123 range from about 0.20 percent in flow group DE8 to about 1.30 percent in flow group DE1-2(1). Potassium contents gradually increase from about $0.20-0.25$ percent in flow groups DE8(1) and E(1), which erupted from vents 127a through 129 about 500 thousand years ago (fig. 7; tables 4 and 5), to about 1.30 percent in flow group DE1-2(1), which erupted from vent 95 at nearly the same time as the rhyolite of Big Southern Butte, vent 94, about 300 thousand years ago. This gradual increase in potassium contents correlates with gradual increases in natural-gamma emissions in many wells, including wells STF-PIE-AQ-01 and ARA-COR-005, in which the reversed-polarity basalt of flow group $F(1)$ (table 6) was found beneath flow group $\mathrm{E}(1)$ or DE8(1) in cores at a depth similar to that estimated using naturalgamma logs from nearby wells (Champion and others, 1996; Anderson and others, 1996a). Although these newly acquired chemical and paleomagnetic data agree with earlier interpretations made using natural-gamma logs, the data also may indicate the need for two changes in the stratigraphic framework. Basalt-flow group $\mathrm{E}(1)$ at the ICPP probably is not the same as flow group $\mathrm{E}(1)$ at the RWMC because their potassium contents differ by about 0.30 percent. Also, basaltflow group $F(1)$, because of its greater-thanexpected thickness in wells STF-PIE-AQ-01 and ARA-COR-005 and revised younger ${ }^{40} \mathrm{Ar} /{ }^{39} \mathrm{Ar}$ age (Champion and others, 1996), probably includes flow group $\mathrm{EF}(1)$ in most places. The previous age of flow group $\mathrm{F}$, based on $\mathrm{K}-\mathrm{Ar}$ measurements, was $565 \pm 14$ thousand years (Champion and others, 1988). The revised measured age of flow group $F(1)$ is $550 \pm 10$ thousand years and is nearly identical to the age 
of 549 thousand years estimated for flow group EF(1) (Anderson and others, 1997).

Stratigraphic interpretations are dependent, in part, on geologic ages of volcanic units, especially those of basalt; however, ages have been measured for relatively few units, often have large associated uncertainties, and sometimes do not agree with ages suggested or required by paleomagnetic, petrographic, chemical, or geophysical-log data (Smith and others, 1996). Spurious measured ages are difficult to identify unless they are from a succession of ages in a single core, are from adjacent cores of identical or similar stratigraphic intervals, contradict known ages of paleomagnetic polarity intervals, or contradict known stratigraphic relations between outcrops and the subsurface. Spurious measured ages are suspected for some cores and outcrops, and many of these ages presently are being reevaluated. On the basis of estimated ages reported by Anderson and others (1997), measured ages of seven basalt outcrops, basalt-flow groups $\mathrm{AB}(8), \mathrm{AB}(13), \mathrm{AB}(37)$, $\mathrm{AB}(38), \mathrm{B}(1), \mathrm{DE} 1(1)$, and DE6(1) (table 4), are suspected of being too young or too old (table 8). However, only one of these outcrops, flow group $\mathrm{AB}(8)$, has been remeasured at this time. The age of flow group $\mathrm{AB}(8)$, which corresponds to Crater Butte (Kuntz and others, 1994), was revised from $519 \pm 52$ to $292 \pm 58$ thousand years (M.A.

Lanphere, USGS, written commun., 1994). Geologic ages of outcrops such as flow group $\mathrm{AB}(8)$ are, in places, difficult to evaluate with respect to those of units in the subsurface. However, based on the interpreted ages and distribution of units in the subsurface, ages of basalt-flow groups $\mathrm{Al}(2)$ through $\mathrm{Al}(13)$, vents 5 through 16 (fig. 7; table 4), probably all are less than 200 thousand years. Ages of basalt-flow groups $\mathrm{AB}(2)$ through $\mathrm{AB}(58)$, vents 17 through 73 (fig. 7; table 4), probably are between the measured ages of flow groups $A B(10)$ and $A B(29), 218 \pm 49$ and $207 \pm 65$ thousand years, respectively, and flow group $\mathrm{BC}(1), 247 \pm 46$ thousand years (table 5). The relative ages among basalt-flow groups $\mathrm{Al}(2)$ through $\mathrm{Al}(13)$ and $\mathrm{AB}(2)$ through $\mathrm{AB}(58)$ are known only for adjacent flow groups (Kuntz and others, 1994) and are tentative elsewhere (fig. 7; table 4). Ages and paleomagnetic polarity of stratigraphic units $\mathrm{Au}(1)$ through $\mathrm{Au}(5), \mathrm{Al}(1)$ through $\mathrm{Al}(13)$,
$A B(1)$ through DE3-4(2), DE3-4(3) through $\mathrm{KL}(1)$, and $\mathrm{L}(1)$ through S5(1) generally coincide with ages and polarity of geologic map units, Qba, Qbb, Qbc, Qbd, and Qbe (Kuntz and others, 1994), respectively; however, agreement between measured and estimated ages for many individual units is poor.

\section{Hydrologic Implications}

The movement of water and waste in the unsaturated zone and aquifer are dependent on many factors including the stratigraphy, structure, and lithology of deposits. Important local stratigraphic and lithologic features that affect the movement of water and waste at the INEL, described in other reports, include sedimentary interbed $\mathrm{CD}(1)$ at the RWMC (Anderson and Lewis, 1989), basalt-flow groups I(1) and I(2) at the ICPP and TRA (Anderson, 1991; Morin and others, 1993; Frederick and Johnson, 1996), and sedimentary interbed QR(1) at TAN (Kaminsky and others, 1994; Anderson and Bowers, 1995). Local stratigraphic, structural, and lithologic features, which include inclined layers, possible fractured basalt flows, and abrupt lateral changes in ages and sediment content of stratigraphic intervals attributed to past differential subsidence and uplift (fig. 6), also may affect the movement of water and waste (Anderson, 1991; Anderson and Bowers, 1995). The locations of concealed stratigraphic and lithologic features attributed to areas of past differential subsidence and uplift at and near the CTF, TAN, and RWMC (figs. 6 and 8-15) and past differential subsidence beneath the Big Lost River (Anderson and others, 1997) coincide with the locations of observed changes in hydraulic gradients of the water table at the INEL (Lewis and Goldstein, 1982; Pittman and others, 1988; Orr and Cecil, 1991; Bartholomay and others, 1995). Hydraulic gradients range from about 1 to $15 \mathrm{ft} / \mathrm{mi}$, average about $4 \mathrm{ft} / \mathrm{mi}$, and are greatest between the areas of interpreted uplift at and near the CTF, TAN, and RWMC and the area mountainward of the Big Lost River (fig. 6). Average hydraulic gradients change from less than $1 \mathrm{ft} / \mathrm{mi}$ at and near the CTF and TAN to about $8 \mathrm{ft} / \mathrm{mi}$ in the areas immediately south of these facilities. This change coincides with 
changes in sediment content ranging from about 10 percent in composite units 8 through 14 (Anderson and Bowers, 1995) to as much as 100 percent in the younger stratigraphic intervals of composite units 1 through 7 on and near the concealed uplift (figs. 6, 9, 13, and 15; table 9). Average hydraulic gradients change from about $8 \mathrm{ft} / \mathrm{mi}$ immediately north of the area of interpreted uplift at and near the RWMC to less than $2 \mathrm{ft} / \mathrm{mi}$ within this area of uplift. This change in hydraulic gradients coincides with northeastward dips of about $270 \mathrm{ft} / \mathrm{mi}$, opposite the direction of ground-water flow, in stratigraphic intervals of composite units 4 through 12 near the concealed uplift (figs. 6 and 12). This uplift and the associated change in hydraulic gradients also coincide with a zone of numerous fissures, dikes, and past eruptions of basalt, andesite, and rhyolite (fig. 7; table 4) referred to as the Arco-Big Southem Butte volcanic rift zone (Lewis and Goldstein, 1982; Kuntz and others, 1992). Average hydraulic gradients mountainward of the Big Lost River, although difficult to determine because of few wells in this area (fig. 2), generally are greater than those basinward of the river. The area mountainward of the river has the least saturated thickness of the aquifer at the INEL (figs 10 and 11 ; table 3), and is underlain, in places, by thick layers of sediment (Anderson and others, 1996a). The coincidence of changes in hydraulic gradients and concealed stratigraphic and lithologic features attributed to past differential subsidence and uplift (fig. 6) suggests that these features may affect the movement of water and waste in the aquifer at and near the INEL. Possible effects of the area of interpreted uplift at and near the ICPP, TRA, CFA, and NRF (fig. 6) are uncertain because hydraulic gradients in this area are complicated by intermittent recharge from the Big Lost River.

\section{SUMMARY AND CONCLUSIONS}

The unsaturated zone and the Snake River Plain aquifer are made up of at least 178 basaltflow groups, 103 sedimentary interbeds, 6 andesite-flow groups, and 4 rhyolite domes at and near the INEL. Stratigraphic units identified in 333 wells include 121 basalt-flow groups, 102 sedimentary interbeds, 6 andesite-flow groups, and 1 rhyolite dome. Stratigraphic units were identified and correlated using the data from numerous outcrops and 26 continuous cores and 328 natural-gamma logs available in December 1993. Basalt flows make up about 85 percent of the volume of deposits underlying the area.

Several types of data were used to identify and correlate stratigraphic units. Basalt, sediment, andesite, and rhyolite were identified from outcrops and cores selectively evaluated for paleomagnetic inclination and polarity, K-Ar and ${ }^{40} \mathrm{Ar} /{ }^{39} \mathrm{Ar}$ geologic ages, petrographic characteristics, and major-oxide and trace-element chemical composition. Stratigraphic units were correlated using these data and natural-gamma logs, which respond to potassium contents of generally less than 1 percent in basalt to more than 4 percent in rhyolite. The best stratigraphic correlations at and near the INEL were obtained for basalt and sediment at the CTF, TAN, NRF, TRA, ICPP, CFA, and RWMC, where most cores and two thirds of the logs were obtained. Correlations range from good at the RWMC to uncertain in the eastern half of the INEL.

Fourteen composite stratigraphic units, each made up of 5 to 90 stratigraphic units of similar age, are used to describe the stratigraphy of the unsaturated zone and aquifer. Upper and lower boundaries of each composite unit were selected to show the main stratigraphic and structural features underlying the area. Composite unit 1 , the youngest unit, is made up of 78 basalt-flow groups and 12 sedimentary interbeds. Composite unit 14, the oldest unit, is made up of 4 basaltflow groups and 1 sedimentary interbed. The decrease in the number of stratigraphic units assigned to each successively older composite unit is attributed partly to larger and less-frequent volcanic eruptions during the accumulation of these units and partly to the limited distribution of available cores used to identify stratigraphic units at greater depths in the subsurface. Composite units 1 through 7 generally range in age from about 200 to 800 thousand years and make up the unsaturated zone and the uppermost part of the Snake River Plain aquifer in most places. Composite units 8 through 14 range in age from about 800 thousand to 1.8 million years and make 
up the unsaturated zone and aquifer at and near the CTF and TAN and the lowermost part of the aquifer elsewhere. Water levels in the aquifer in 1996 coincided with composite units 4 and 5 in most places; water levels coincided with composite unit 12 at and near the CTF and TAN.

Hydraulic gradients of the water table range from about 1 to $15 \mathrm{ft} / \mathrm{mi}$, average about $4 \mathrm{ft} / \mathrm{mi}$, and, in places, change at or near stratigraphic and lithologic features attributed to past differential subsidence and uplift. Average hydraulic gradients change from less than $1 \mathrm{ft} / \mathrm{mi}$ at and near the CTF and TAN, an area of interpreted uplift, to about $8 \mathrm{ft} / \mathrm{mi}$ in the areas immediately south of these facilities. This change coincides with changes in sediment content ranging from about 10 percent in composite units 8 through 14 to as much as 100 percent in the younger stratigraphic intervals of composite units 1 through 7 on and near the concealed uplift. Average hydraulic gradients change from about $8 \mathrm{ft} / \mathrm{mi}$ immediately north of an area of interpreted uplift at and near the RWMC to less than $2 \mathrm{ft} / \mathrm{mi}$ within this area of uplift. This change coincides with northeastward dips of about $270 \mathrm{ft} / \mathrm{mi}$, opposite the direction of ground-water flow, in stratigraphic intervals of composite units 4 through 12 near the concealed uplift and the Arco-Big Southem Butte volcanic rift zone. Average hydraulic gradients mountainward of the Big Lost River, an area of reduced stratigraphic thickness attributed to past differential subsidence, generally are greater than those basinward of the river. The area mountainward of the river has the least saturated thickness of the aquifer at the INEL, and is underlain, in places, by thick layers of sediment. The coincidence of changes in hydraulic gradients and concealed stratigraphic and lithologic features attributed to past differential subsidence and uplift suggests that these features may affect the movement of water and waste in the aquifer at and near the INEL. Possible effects of an area of interpreted uplift at and near the ICPP, TRA, CFA, and NRF are uncertain because hydraulic gradients in this area are complicated by intermittent recharge from the Big Lost River.

Additional cores and data would improve interpretations of stratigraphic relations and their possible hydrologic effects at and near the INEL. Three cores, drilled to a depth of about $1,500 \mathrm{ft}$ near wells USGS 30A, EBR-1, and Site 14 are needed to test the main conceptual elements of the stratigraphic framework presented in this report. Four additional cores, drilled to a depth of at least $750 \mathrm{ft}$ at the NRF, TRA, CFA, and immediately south of the RWMC, are needed to resolve important stratigraphic uncertainties and their possible effects on the movement of water and waste in the unsaturated zone and aquifer. Additional paleomagnetic, geochronologic, petrographic, chemical, and geophysical-log data also are needed for existing cores and wells to improve stratigraphic interpretations at these and other facilities. In some places, stratigraphic interpretations made from $\mathrm{K}-\mathrm{Ar}$ ages and natural-gamma logs might be improved by ${ }^{40} \mathrm{Ar} /{ }^{39} \mathrm{Ar}$ ages and gamma-spectral logs.

\section{REFERENCES CITED}

Ackerman, D.J., 1991, Transmissivity of the Snake River Plain aquifer at the Idaho National Engineering Laboratory, Idaho: U.S. Geological Survey Water-Resources Investigations Report 91-4058 (DOE/ID-22097), 35 p.

Anderson, S.R., 1991, Stratigraphy of the unsaturated zone and uppermost part of the Snake River Plain aquifer at the Idaho Chemical Processing Plant and Test Reactors Area, Idaho National Engineering Laboratory, Idaho: U.S. Geological Survey WaterResources Investigations Report 91-4010 (DOE/ID-22095), $71 \mathrm{p}$.

Anderson, S.R., Ackerman, D.J., Liszewski, M.J., and Freiburger, R.M., 1996a, Stratigraphic data for wells at and near the Idaho National Engineering Laboratory, Idaho: U.S. Geological Survey Open-File Report 96-248 (DOE/ID-22127), 27 p. and 1 diskette.

Anderson, S.R., and Bartholomay, R.C., 1995, Use of natural-gamma logs and cores for determining stratigraphic relations of basalt and sediment at the Radioactive Waste Management Complex, Idaho National Engineering Laboratory, Idaho: Journal of the Idaho Academy of Science, v. 31, no. 1, p. 1-10. 
Anderson, S.R., and Bowers, Beverly, 1995, Stratigraphy of the unsaturated zone and uppermost part of the Snake River Plain aquifer at Test Area North, Idaho National Engineering Laboratory, Idaho: U.S. Geological Survey Water-Resources Investigations Report 95-4130, (DOE/ID-22122) $47 \mathrm{p}$.

Anderson, S.R., and Lewis, B.D., 1989, Stratigraphy of the unsaturated zone at the Radioactive Waste Management Complex, Idaho National Engineering Laboratory, Idaho: U.S. Geological Survey Water-Resources Investigations Report 89-4065 (DOE/ID-22080), $54 \mathrm{p}$.

Anderson, S.R., Liszewski, M.J., and Ackerman, D.J., 1996b, Thickness of surficial sediment at and near the Idaho National Engineering Laboratory, Idaho: U.S. Geological Survey Open-File Report 96-330 (DOE/ID-22128), $16 \mathrm{p}$.

Anderson, S.R., Liszewski, M.J., and Cecil, L.D., 1997, Geologic ages and accumulation rates of basalt-flow groups and sedimentary interbeds in selected wells at the Idaho National Engineering Laboratory, Idaho: U.S. Geological Survey Water-Resources Investigations Report 97-4010 (DOE/ID-22134), 39 p.

Armstrong, R.L., Leeman, W.P., and Malde, H.E., 1975, K-Ar dating, Quaternary and Neogene volcanic rocks of the Snake River Plain, Idaho: American Journal of Science, v. 275, no. 3 , p. $225-251$.

Bartholomay, R.C., 1990, Digitized geophysical logs for selected wells on or near the Idaho National Engineering Laboratory, Idaho: U.S. Geological Survey Open-File Report 90-366 (DOE/ID-22088), 347 p.

Bartholomay, R.C., Orr, B.R., Liszewski, M.J., and Jensen, R.G., 1995, Hydrologic conditions and distribution of selected radiochemical and chemical constituents in water, Snake River Plain aquifer, Idaho National Engineering Laboratory, Idaho, 1989 through 1991: U.S. Geological Survey Water-Resources Investigations Report 95-4175 (DOE/ID-22123), $47 \mathrm{p}$.
Bates, R.L., and Jackson, J.A., eds., 1980, Glossary of geology ( $2 \mathrm{~d}$ ed.): Falls Church, Va., American Geological Institute, 749 p.

Berggren, W.A., Hilgen, F.J., Langereis, C.G., Kent, D.V., Obradovich, J.D., Raffi, I., Raymo, M.E., and Shackleton, N.J., 1995, Late Neogene chronology-new perspectives in high-resolution stratigraphy: Geological Society of America Bulletin, v. 107, no. 11, p. 1,272-1,287.

Cecil, L.D., Orr, B.R., Norton, T., and Anderson, S.R., 1991, Formation of perched groundwater zones and concentrations of selected chemical constituents in water, Idaho National Engineering Laboratory, Idaho, 1986-88: U.S. Geologicai Survey Water-Resources Investigations Report 91-4166 (DOE/ID22100), $53 \mathrm{p}$.

Champion, D.E., Lanphere, M.A., and Anderson, S.R., 1996, Further verification and ${ }^{40} \mathrm{Ar} /{ }^{39} \mathrm{Ar}$ dating of the Big Lost Reversed-Polarity Subchron from drill core subsurface samples of the Idaho National Engineering Laboratory, Idaho [abs.]: American Geophysical Union, December 1996, Abstracts.

Champion, D.E., Lanphere, M.A., and Kuntz, M.A., 1988, Evidence for a new geomagnetic reversal from lava flows in Idaho-discussion of short polarity reversals in the Brunhes and Late Matuyama Polarity Chrons: Journal of Geophysical Research, v. 93, no. B10, p. $11,677-11,680$.

Davis, L.C., Hannula, S.R., and Bowers, Beverly, 1997, Procedures for use of, and drill cores and cuttings available for study at, the Lithologic Core Storage Library, Idaho National Engineering Laboratory, Idaho: U.S. Geological Survey Open-File Report 97-124 (DOE/ID-22135), 31 p.

Doherty, D.J., McBroome, L.A., and Kuntz, M.A., 1979, Preliminary geological interpretation and lithologic log of the exploratory geothermal test well (INEL-1), Idaho National Engineering Laboratory, Eastern Snake River Plain, Idaho: U.S. Geological Survey OpenFile Report 79-1248, 7 p. 
Fishel, M.L., 1993, The geology of uplifted rocks on Big Southern Butte-implications for the stratigraphy and geochemistry of the Eastern Snake River Plain: Idaho State University, M.S. thesis, $178 \mathrm{p}$.

Forman, S.L., Pierson, J., Smith, R.P., Hackett, W.R., and Valentine, G., 1994, Assessing the accuracy of thermoluminescence for dating baked sediments beneath late Quaternary lava flows, Snake River Plain, Idaho: Journal of Geophysical Research, v. 99, no. B8, p. $15,569-15,576$.

Forman, S.L., Smith, R.P., Hackett, W.R., Tullis, J.A., and McDaniel, P.A., 1993, Timing of late Quaternary glaciations in the western United States based on the age of loess on the Eastern Snake River Plain, Idaho: Journal of Quaternary Research, v. 40, p. 30-37.

Frederick, D.B., and Johnson, G.S., 1996, Estimation of hydraulic properties and development of a layered conceptual model for the Snake River Plain aquifer at the Idaho National Engineering Laboratory, Idaho: State of Idaho INEL Oversight Program and Idaho Water Resources Research Institute, Technical Completion Report, 67 p. and 2 appendices

Fromm, J.M., Hackett, W.R., and Stephens, J.D., 1994, Primary mineralogy and alteration of basalts and sediments in drillcores from the Idaho National Engineering Laboratory, eastern Snake River Plain [abs.]: International Symposium on the Observation of the Continental Crust Through Drilling, 7th, Santa Fe, N. Mex., April 25-30, 1994, Abstracts, unpaged.

Hackett, W.R., Anders, M., and Walter, R.C., 1994, Preliminary stratigraphic framework of rhyolites from corehole WO-2, Idaho National Engineering Laboratory-caldera-related, late-Tertiary silicic volcanism of the eastem Snake River Plain [abs.]: International Symposium on the Observation of the Continental Crust Through Drilling, 7th, Santa Fe, N. Mex., April 25-30, 1994, Abstracts, unpaged.
Hayden, K.P., 1992, The geology and petrology of Cedar Butte, Bingham County, Idaho: Idaho State University, M.S. thesis, 104 p.

Kaminsky, J.F., Keck, K.N., Schafer-Perini, A.L., Hersley, C.F., Smith, R.P., Stormberg, G.J., and Wylie, A.H., 1994, Remedial investigation final report with addenda for the Test Area North groundwater operable unit 1-07B at the Idaho National Engineering Laboratory, volume 1: Idaho Falls, Idaho, EG\&G Idaho, Inc. Report EGG-ER-10643, variously paged [available from U.S. Department of Energy, Idaho Operations Office, 785 DOE Place, Idaho Falls, ID 83401-1562].

Kimmel, P.G., 1982, Stratigraphy, age, and tectonic setting of the Miocene-Pliocene lacustrine sediments of the western Snake River Plain, Oregon and Idaho, in Bonnichsen, B., and Breckenridge, R.M., eds., Cenozoic geology of Idaho: Idaho Bureau of Mines and Geology Bulletin 26, p. 559-578.

Knobel, L.L., Cecil, L.D., and Wood, T.R., 1995, Chemical composition of selected core samples, Idaho National Engineering Laboratory, Idaho: U.S. Geological Survey OpenFile Report 95-748, 59 p.

Kuntz, M.A., Covington, H.R., and Schorr, L.J., 1992, An overview of basaltic volcanism of the eastern Snake River Plain, Idaho, in Link, P.K., Kuntz, M.A., and Platt, L.B., eds., Regional geology of eastern Idaho and western Wyoming: Geological Society of America Memoir 179, p. 227-267.

Kuntz, M.A., Dalrymple, G.B., Champion, D.E., and Doherty, D.J., 1980, Petrography, age, and paleomagnetism of volcanic rocks at the Radioactive Waste Management Complex, Idaho National Engineering Laboratory, Idaho, with an evaluation of potential volcanic hazards: U.S. Geological Survey Open-File Report 80-388, 63 p. 
Kuntz, M.A., Skipp, Betty, Lanphere, M.A., Scott, W.E., Pierce, K.L., Dalrymple, G.B., Champion, D.E., Embree, G.F., Page, W.R., Morgan, L.A., Smith, R.P., Hackett, W.R., and Rodgers, D.W., 1994, Geologic map of the Idaho National Engineering Laboratory and adjoining areas, eastern Idaho: U.S. Geological Survey Miscellaneous Investigations Map I-2330, scale 1:100,000.

Lanphere, M.A., Champion, D.E., and Kuntz, M.A., 1993, Petrography, age, and paleomagnetism of basalt lava flows in coreholes Well 80, NRF 89-04, NRF 89-05, and ICPP 123, Idaho National Engineering Laboratory, Idaho: U.S. Geological Survey Open-File Report 93-327, 40 p.

Lanphere, M.A., Kuntz, M.A., and Champion, D.E., 1994, Petrography, age, and paleomagnetism of basaltic lava flows in coreholes at Test Area North (TAN), Idaho National Engineering Laboratory: U.S. Geological Survey Open-File Report 94-686, 49 p.

Lawrence, R.F., and Hackett, W.R., 1994, Petrography and lithology of Tertiary rhyolites in WO-2 drillcore, Idaho National Engineering Laboratory (INEL), eastern Snake River Plain [abs.]: International Symposium on the Observation of the Continental Crust through Drilling, 7th, Santa Fe, N. Mex., April 25-30, 1994, Abstracts, unpaged.

Le Bas, M.J., Le Maitre, R.W., Streckeisen, A., and Zanettin, B., 1986, A chemical classification of volcanic rocks based on the total alkali-silica diagram: Journal of Petrology, v. 27, p. $745-750$.

Lewis, B.D., and Goldstein, F.G., 1982, Evaluation of a predictive ground-water solute-transport model at the Idaho National Engineering Laboratory, Idaho: U.S. Geological Survey Water- Resources Investigations Report 82-25 (IDO-22062), $71 \mathrm{p}$.
Mann, L.J., 1986, Hydraulic properties of rock units and chemical quality of water for INEL-1- a 10,365-foot deep test hole drilled at the Idaho National Engineering Laboratory, Idaho: U.S. Geological Survey WaterResources Investigations Report 86-4020 (IDO-22070), 23 p.

Morin, R.H., Barrash, Warren, Paillet, F.L., and Taylor, T.A., 1993, Geophysical logging studies in the Snake River Plain aquifer at the Idaho National Engineering Laboratorywells 44, 45, and 46: U.S. Geological Survey Water-Resources Investigations Report 924184, $44 \mathrm{p}$.

Orr, B.R., and Cecil, L.D., 1991, Hydrologic conditions and distribution of selected chemical constituents in water, Snake River Plain aquifer, Idaho National Engineering Laboratory, Idaho, 1986 to 1988: U.S. Geological Survey Water-Resources Investigations Report 91-4047 (DOE/ID- 22096), 56 p.

Ott, D.S., Edwards, D.D., and Bartholomay, R.C., 1992, Water-level data for selected wells on or near the Idaho National Engineering Laboratory, Idaho, 1983 through 1990: U.S. Geological Survey Open-File Report 92-643 (DOE/ID-22105), 307 p.

Pittman, J.R., Jensen, R.G., and Fischer, P.R., 1988, Hydrologic conditions at the Idaho National Engineering Laboratory, 1982 to 1985: U.S. Geological Survey WaterResources Investigations Report 89-4008 (DOE/ID-22078), 73 p.

Reed, M.F., Bartholomay, R.C., and Hughes, S.S., 1997, Geochemistry and stratigraphic correlation of basalt lavas beneath the Idaho Chemical Processing Plant, Idaho National Engineering Laboratory: Environmental Geology, v. 30 , p. $108-118$.

Repenning, C.A., Weasma, T.R., and Scott, G.R., 1995, The early Pleistocene (latest Blancanearliest Irvingtonian) Froman Ferry Fauna and history of the Glenns Ferry Formation, southwestern Idaho: U.S. Geological Survey Bulletin 2105, $86 \mathrm{p}$. 
Shervais, John, Vetter, Scott, and Hackett, William, 1994, Chemical stratigraphy of basalts in coreholes NPR-E and WO-2, Idaho National Engineering Laboratory, Idahoimplications for plume dynamics in the Snake River Plain: International Symposium on the Observation of the Continental Crust Through Drilling, 7th, Santa Fe, N. Mex., April 25-30, 1994, Proceedings, p. 93-96.

Smith, R.P., Hackett, W.R., Josten, N.E., Knutson, C.F., Jackson, S.M., Barton, C.A., Moos, D., Blackwell, D.D., and Kelley, S., 1994, Synthesis of deep drill hole information at the Idaho National Engineering Laboratory (INEL) - upper crustal environment in the continental track of a mantle hotspot: International Symposium on the Observation of the Continental Crust Through Drilling, 7th, Santa Fe, N. Mex., April 25-30, 1994, Proceedings, p. 89-92.

Smith, R.P., Hersley, C.F., and Jackson, S.M., 1996, Summary of information relating to correlation of strata beneath the Idaho Chemical Processing Plant and Test Reactor Area, Idaho National Engineering Laboratory: Idaho Falls, Idaho, LITCO, Engineering Design File Report TRA-ATR-1163, 17 p. [available from U.S. Department of Energy, Idaho Operations Office, 785 DOE Place, Idaho Falls, ID 83401-1562].

Walker, E.H., 1964, Subsurface geology of the National Reactor Testing Station, Idaho: U.S. Geological Survey Bulletin 1133-E, 22 p., 2 pls. in pocket.

Welhan, J.A., Funderberg, T., and Smith, R.P., 1997, Stochastic modeling of hydraulic conductivity in the Snake River Plain aquifer-1. Hydrological constraints and conceptual approach: in Sharma, Sunil and Hardcastle, J.H. eds., Proceedings of the 32nd Symposium on Engineering Geology and Geotechnical Engineering, Boise, Id., March 26-28, 1997, p. 75-91.
Wetmore, P.H., Hughes, S.S., and Anderson, S.R., 1997, Model morphologies of subsurface Quaternary basalts as evidence for a decrease in the magnitude of basaltic magmatism at and near the Idaho National Engineering and Environmental Laboratory, Idaho: in Sharma, Sunil and Hardcastle, J.H. eds., Proceedings of the 32nd Symposium on Engineering Geology and Geotechnical Engineering, Boise, Id., March 26-28, 1997, p. 45-58.

Whitehead, R.L., 1992, Geohydrologic framework of the Snake River Plain regional aquifer system, Idaho and eastem Oregon: U.S. Geological Survey Professional Paper 1408-B, 32 p., 6 pls. in pocket.

Whitehead, R.L, and Lindholm, G.F., 1985, Results of geohydrologic test drilling in the eastern Snake River Plain, Gooding County, Idaho: U.S. Geological Survey WaterResources Investigations Report 84-4294, $30 \mathrm{p}$. 


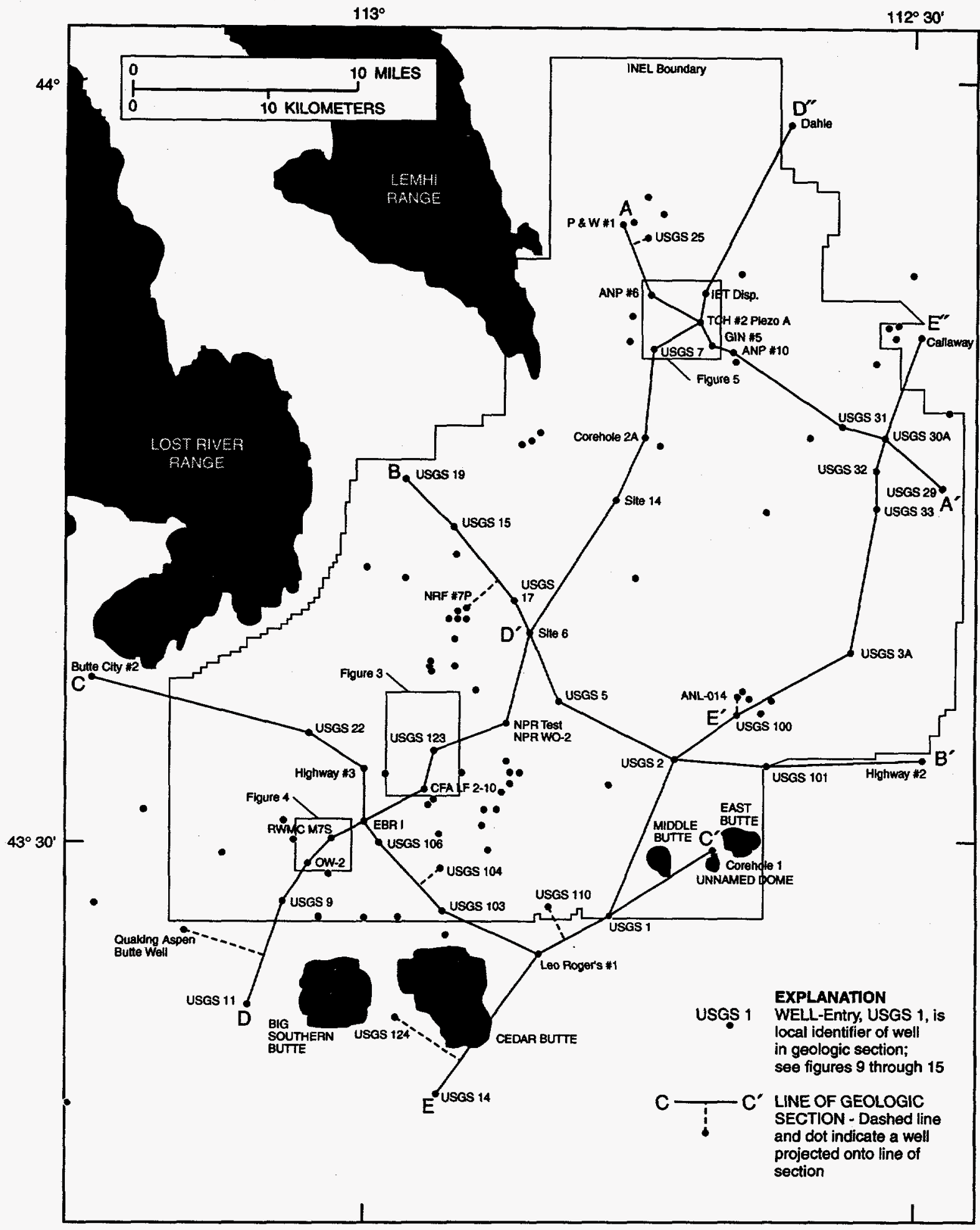

Figure 8. Locations of geologic sections A-A' through E'-E'" at and near the Idaho National Engineering Laboratory 
BASALT-FIOW GROUPS AND SEDIMENTARY

INTERBEDS A THROUGH L - Includes unaltered basalt and sediment in the youngest part of the unsaturated zone and the Snake River Plain aquifer; locally includes andesite and ityolite. Age of sequence generally ranges from about 200 to 800 thousand years (ka) and is

consistent with that of the Snake River Group. Number, 4 is a composite stratigraphic unit from table 4

BASALT-FLOW GROUPS AND SEDIMENTARY

INTERBEDS LM1 THROUGH S5 - Includes unaltered to

altered basalt and sediment in the oldest part of the

unsaturated zone and the Snake River Plain aquifer;

locally includes andesite and thyolite. Age of sequence

generally ranges from about 800 thousand to 1.8 million

years (ma) and is consistent with that of the Bruneau

Formation. Number, 10 is a composite stratigraphic un

from table 4

BASALT-FLOW GROUPS AND SEDIMENTARY

INTERBEDS, UNDIFFERENTIATED - Includes altered basalt and sediment that form the effective base of the Snake River Plain aquifer; locally may include andesite and myolite. Age of sequence generally ranges from about 1.8 to 4.0 million years and is consistent with that of the Glenns Ferry Formation

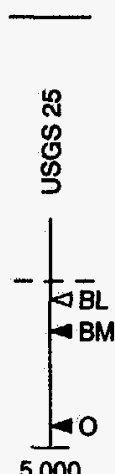

GEOLOGIC CONTACT - Queried where uncertain

WELL - Dashed where projected to sections. Entry, USGS 25, is local well identifier; see figure 8. Dashed horizontal line indicates measured or estimated water level in aquifer in 1996. Arrows indicate tops of probable paleomagnetic chrons and subchrons; solid arrows indicate data from cores. E (Emperor, $465 \mathrm{ka}$ ), BL (Big

Lost, $550 \mathrm{ka}$ ), BM (Brunhes/ Matuyama, $780 \mathrm{ka}$ ), J

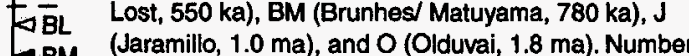

5,000 , at bottom of well is total depth of well, in feet below land surface

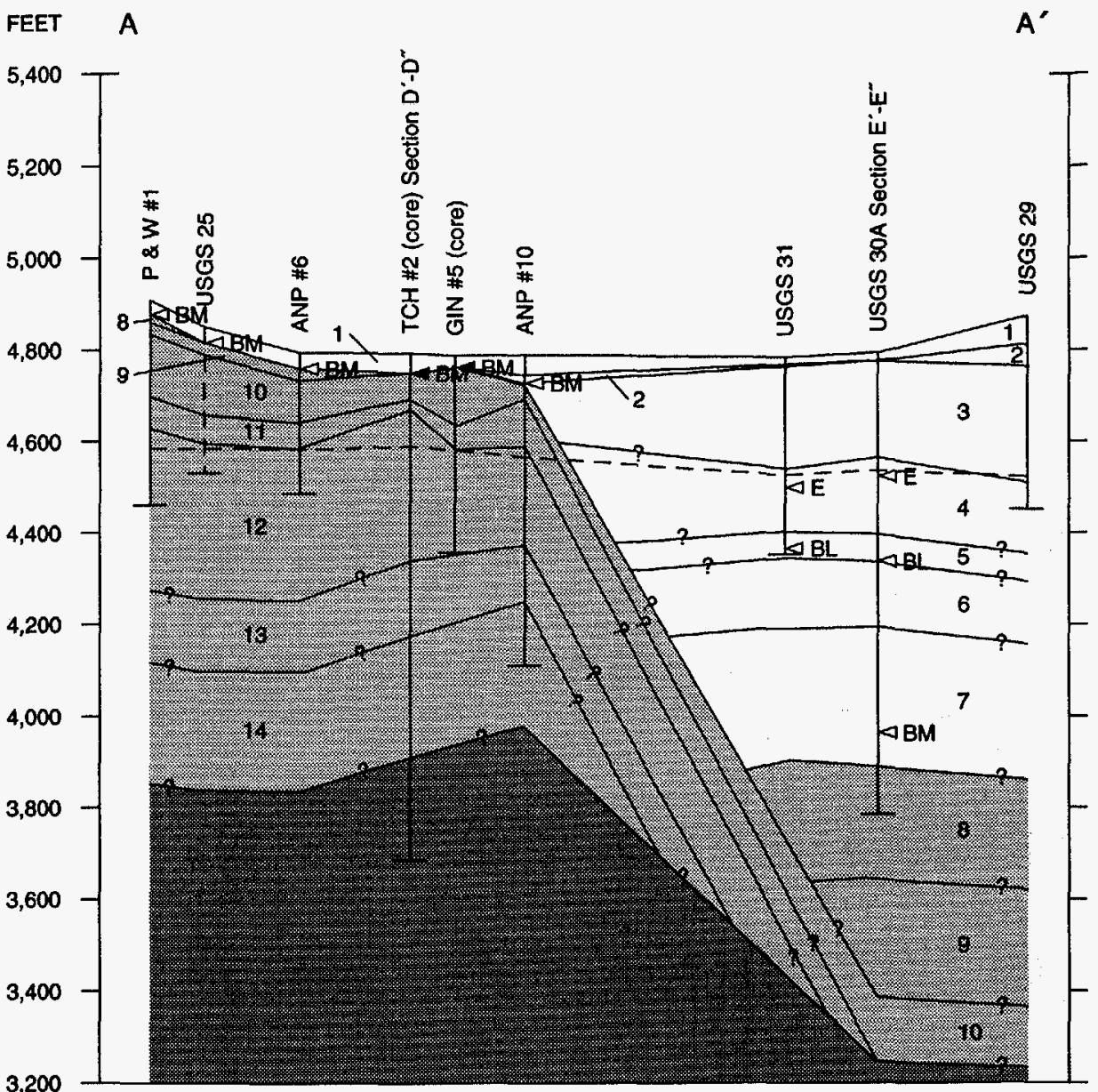

VERTICAL SCALE GREATLY EXAGGERATED

DATUM IS SEA LEVEL

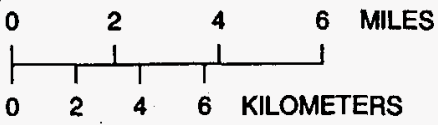

Figure 9. Geologic section $A-A^{\prime}$ at the Idaho National Engineering Laboratory. 


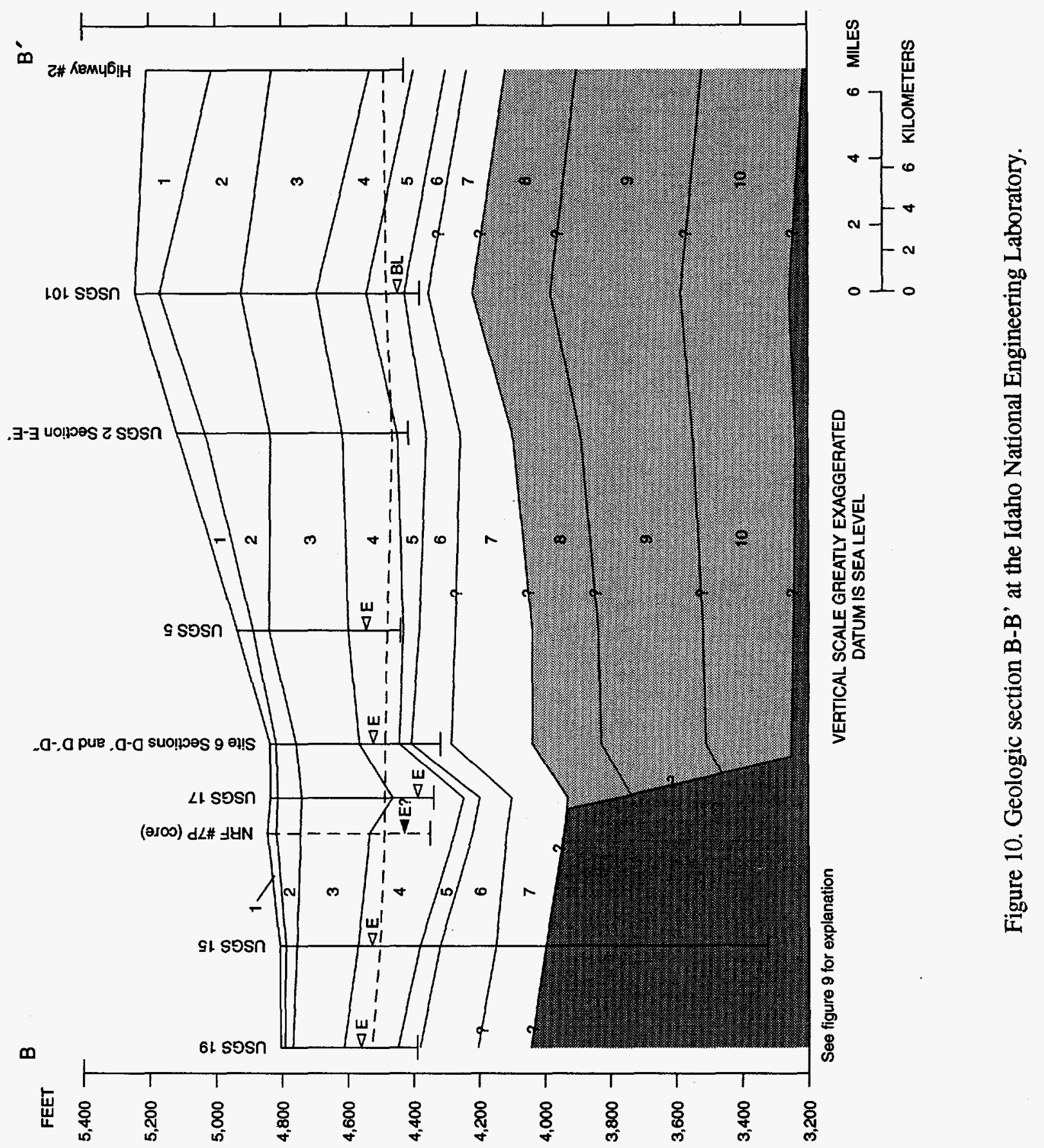




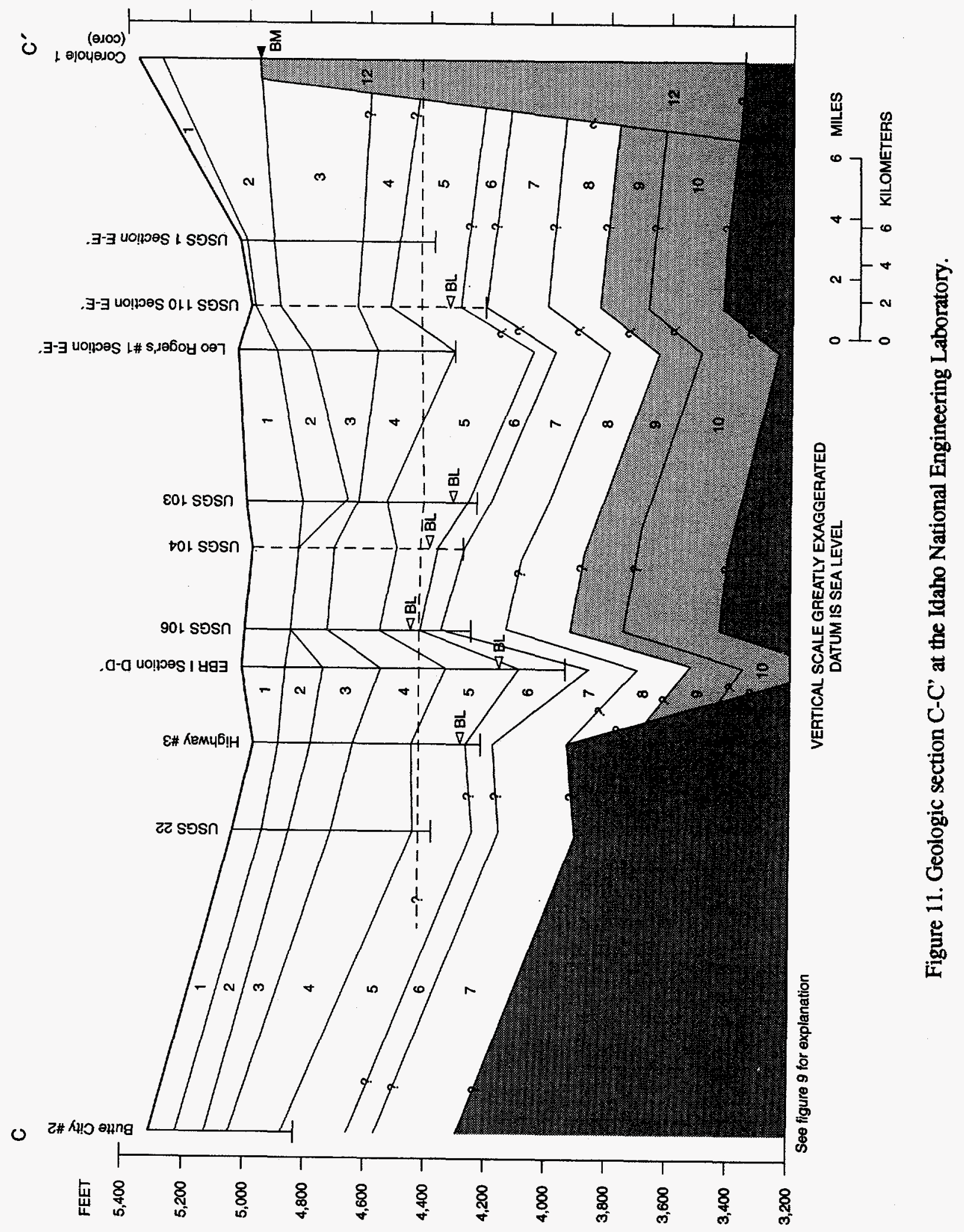




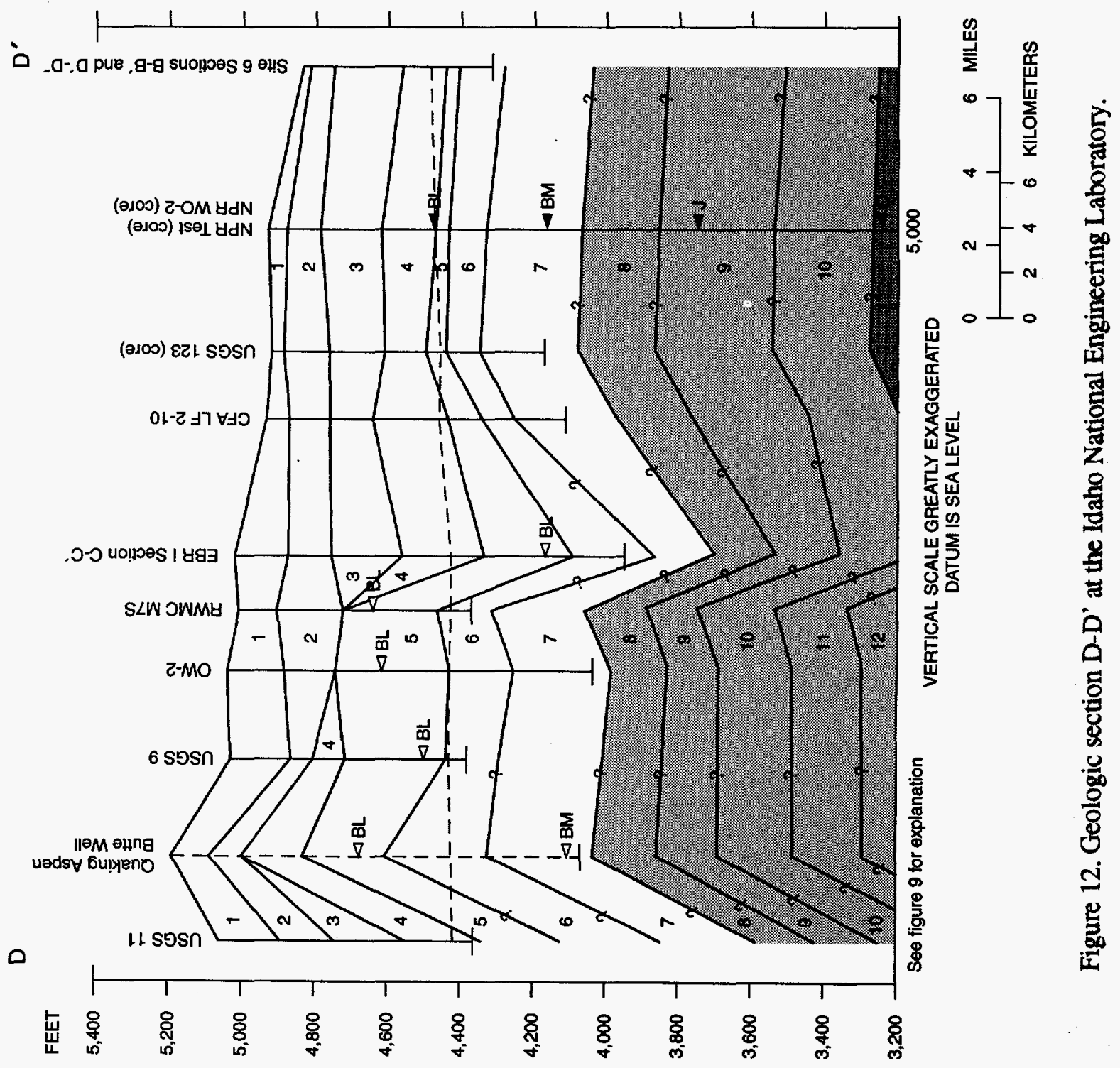




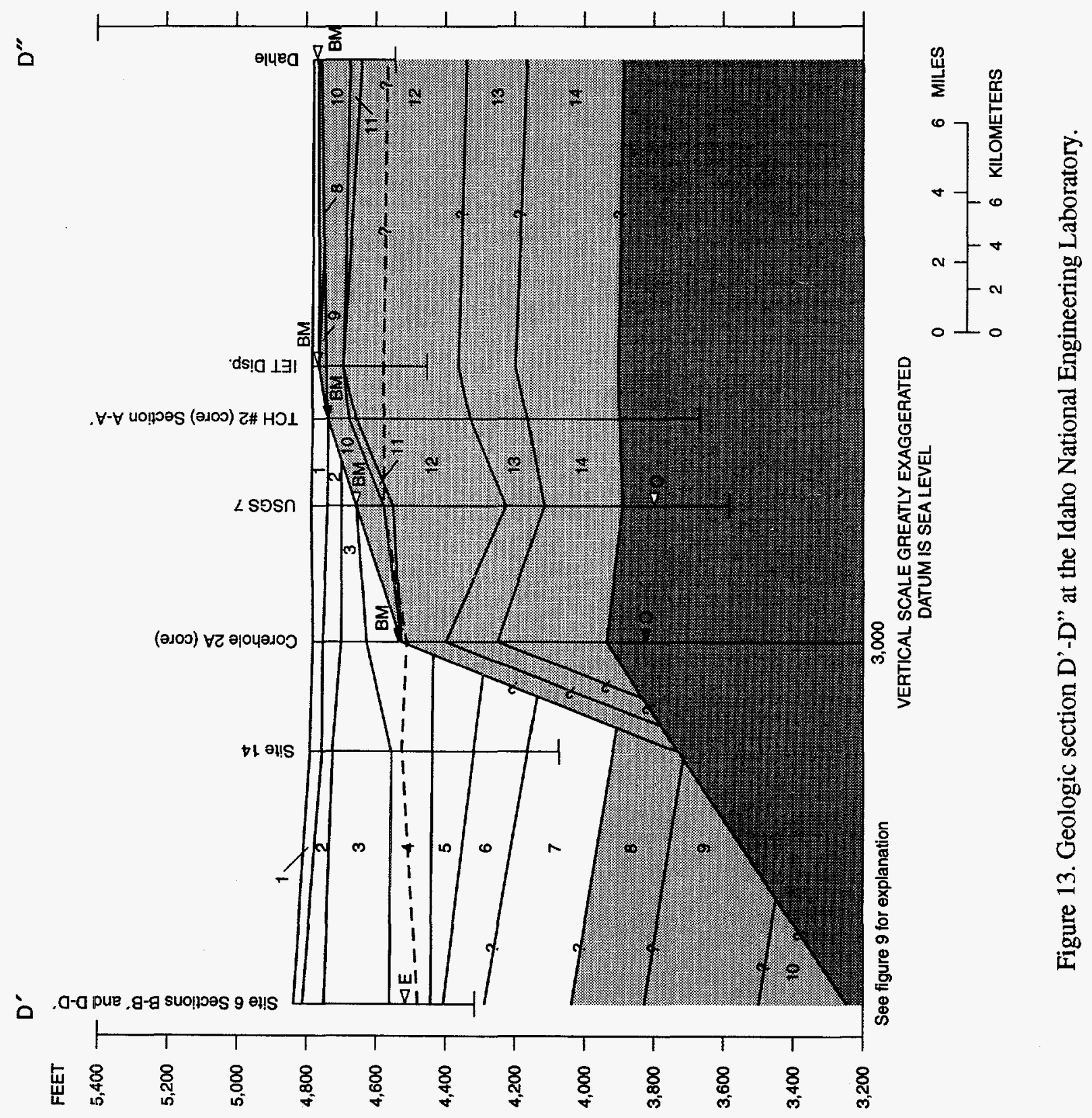




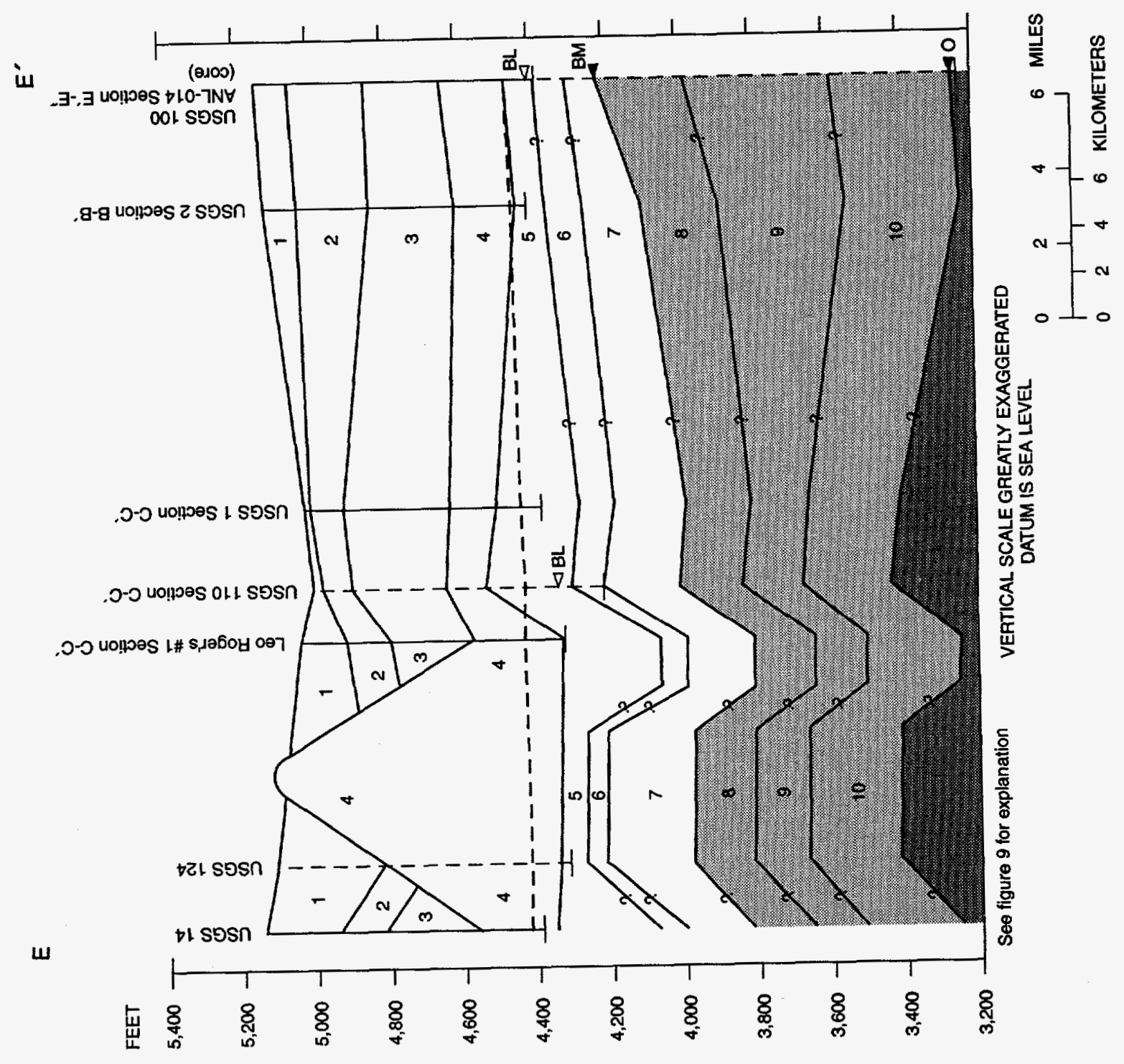

ह⿱宀 


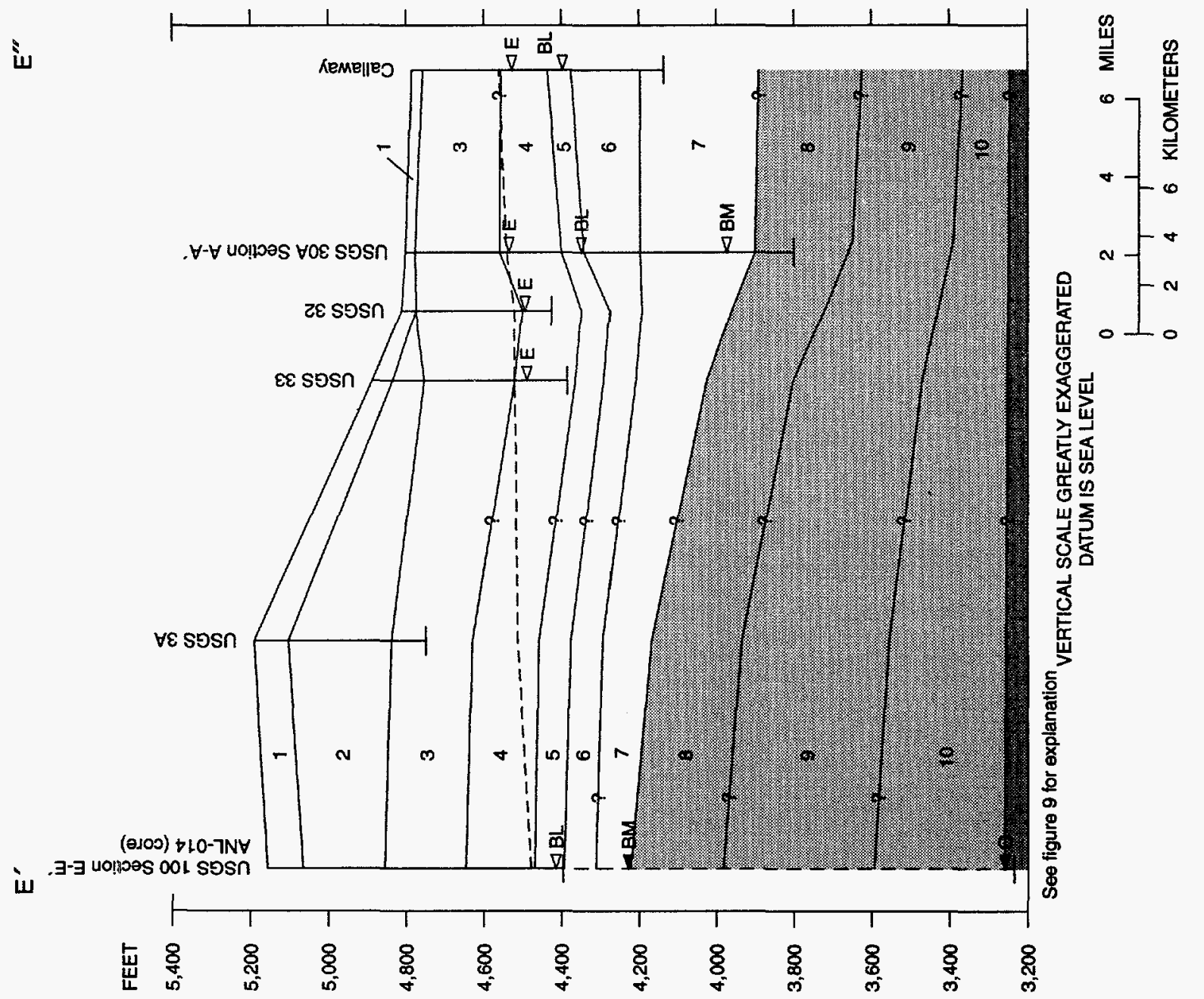

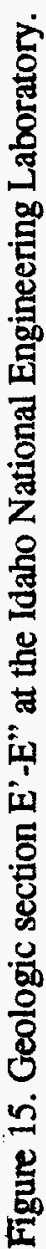




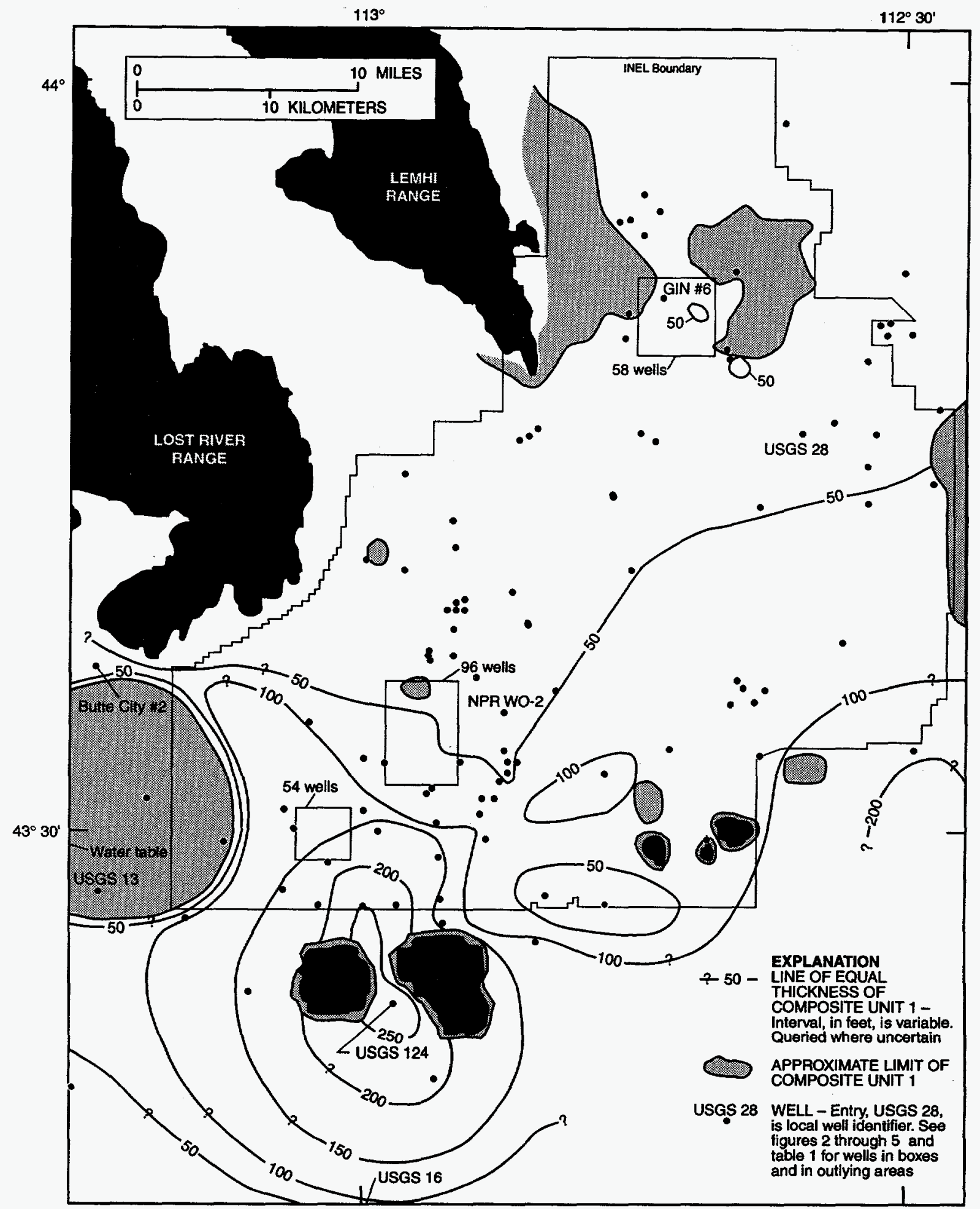

Figure 16. Thickness of composite stratigraphic unit 1 at the Idaho National Engineering Laboratory. 


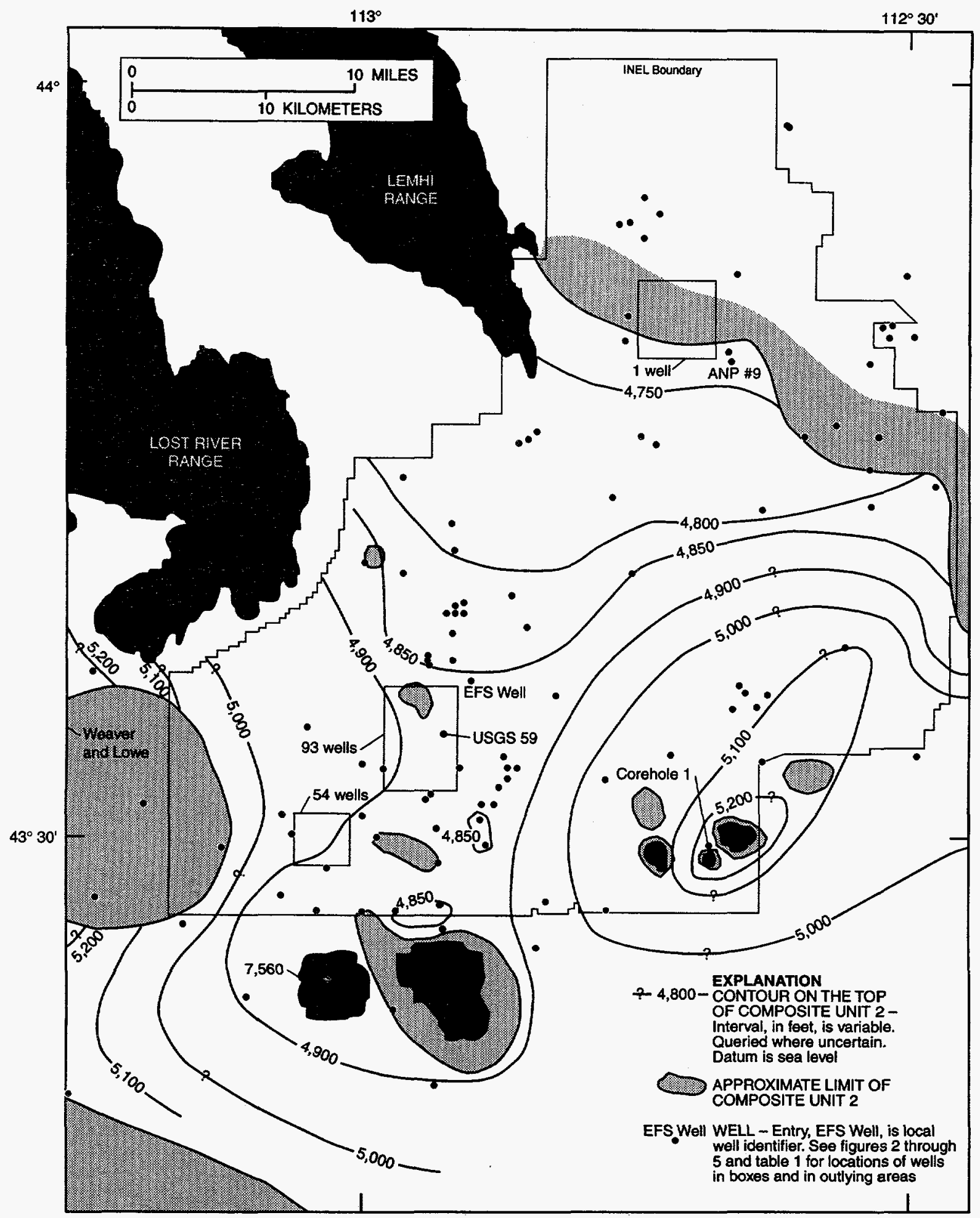

Figure 17. Altitude of the top of composite stratigraphic unit 2 at the Idaho National Engineering Laboratory. 


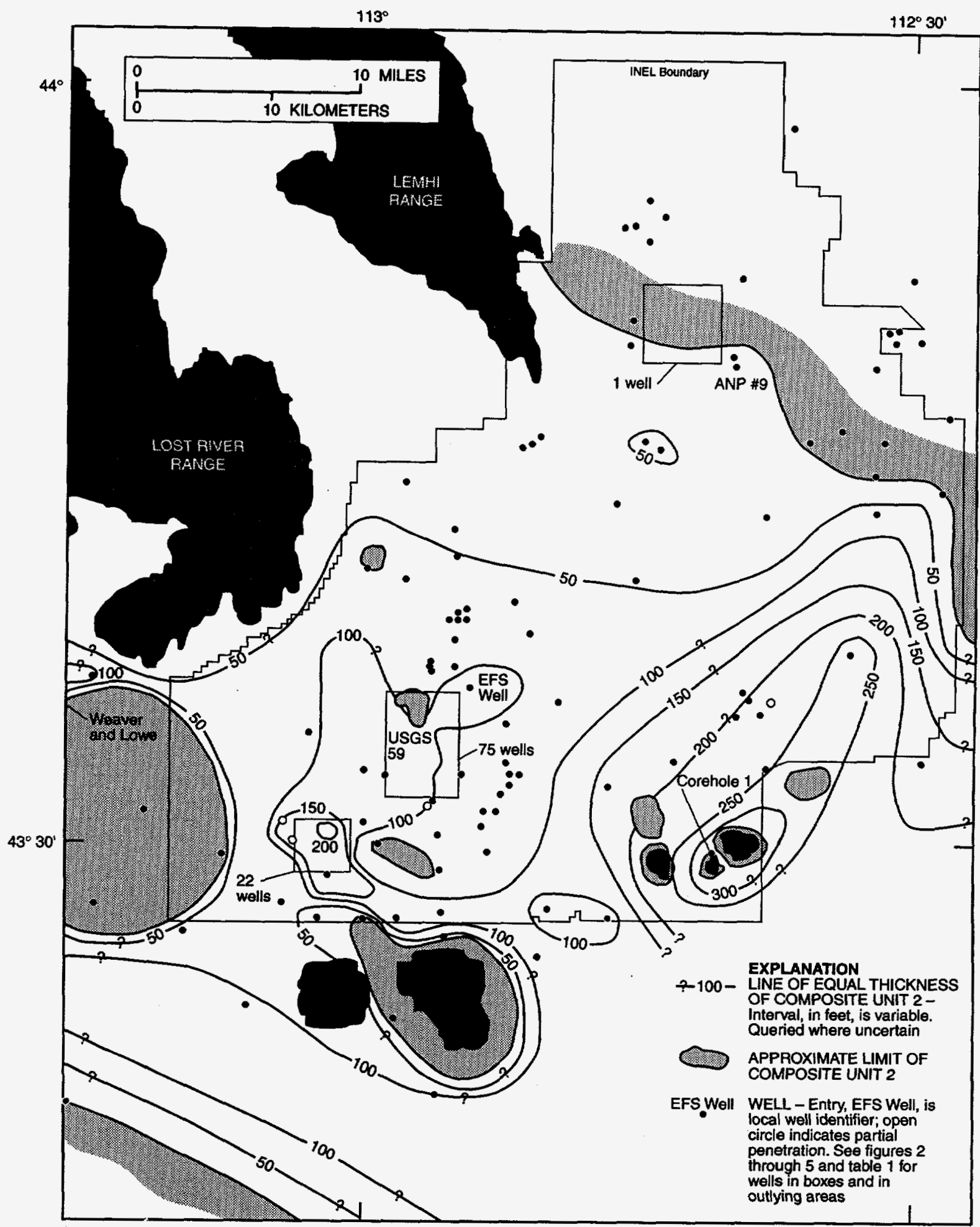

Figure 18. Thickness of composite stratigraphic unit 2 at the Idaho National Engineering Laboratory. 


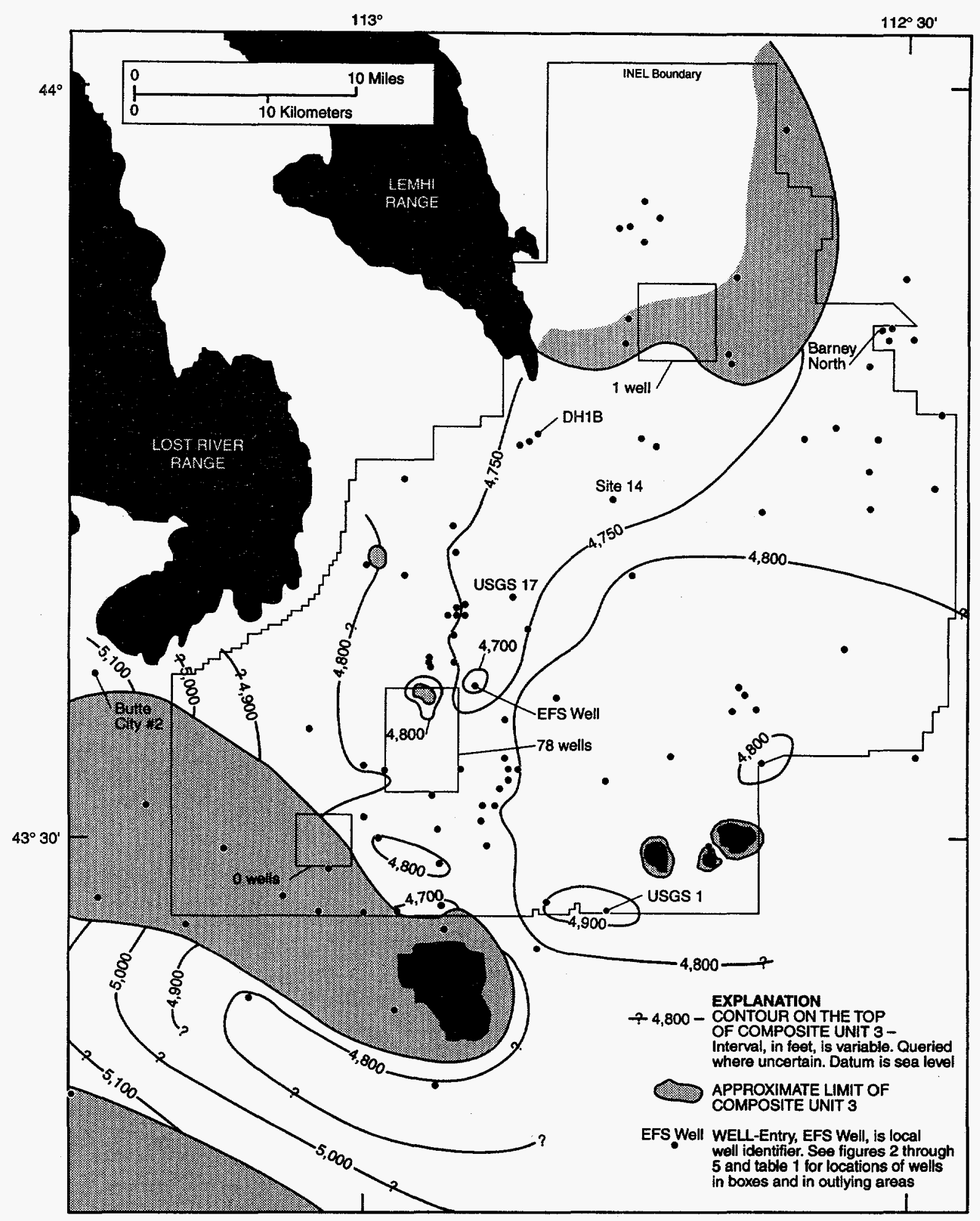

Figure 19. Altitude of the top of composite stratigraphic unit 3 at the Idaho National Engineering Laboratory. 


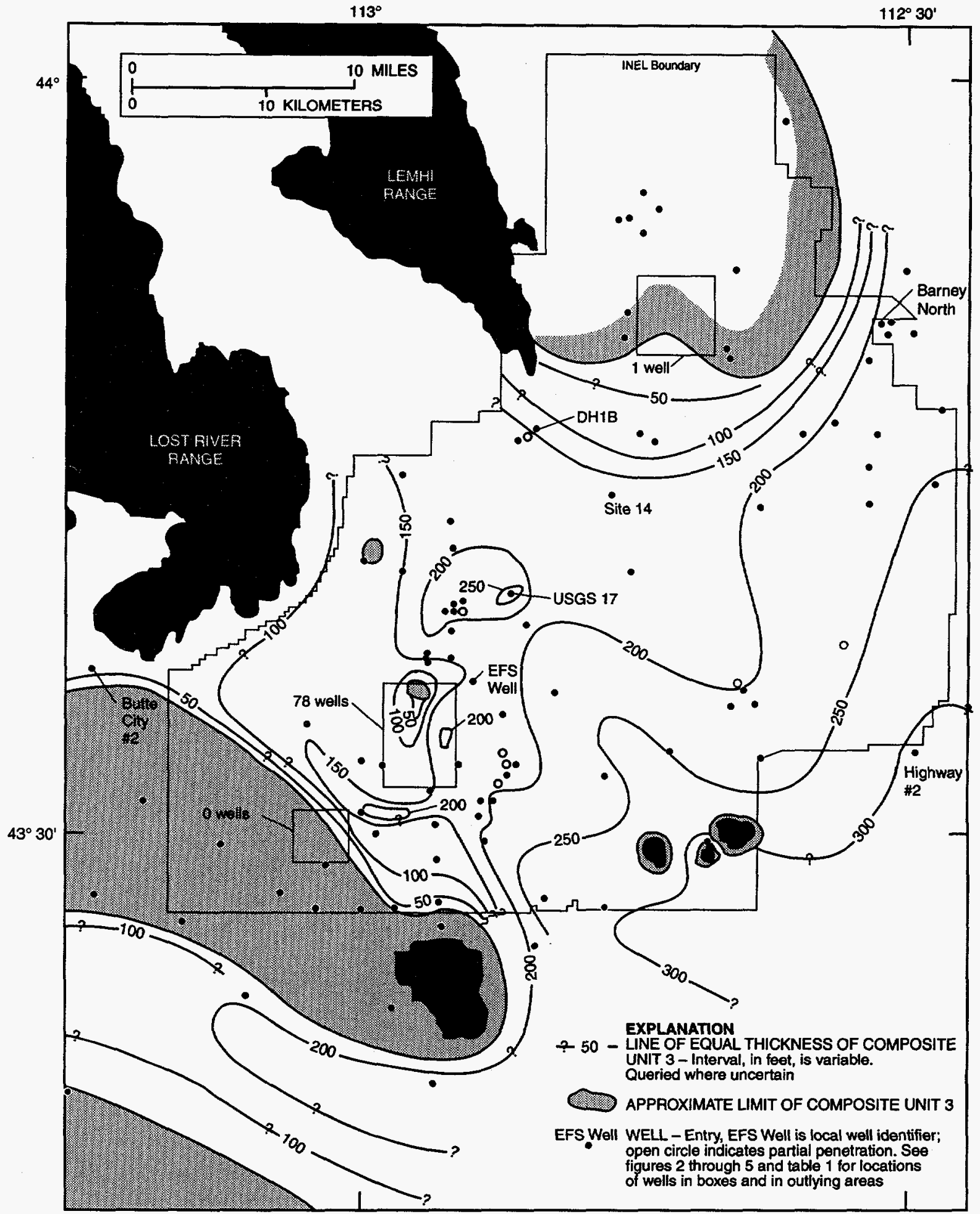

Figure 20. Thickness of composite stratigraphic unit 3 at the Idaho National Engineering Laboratory. 


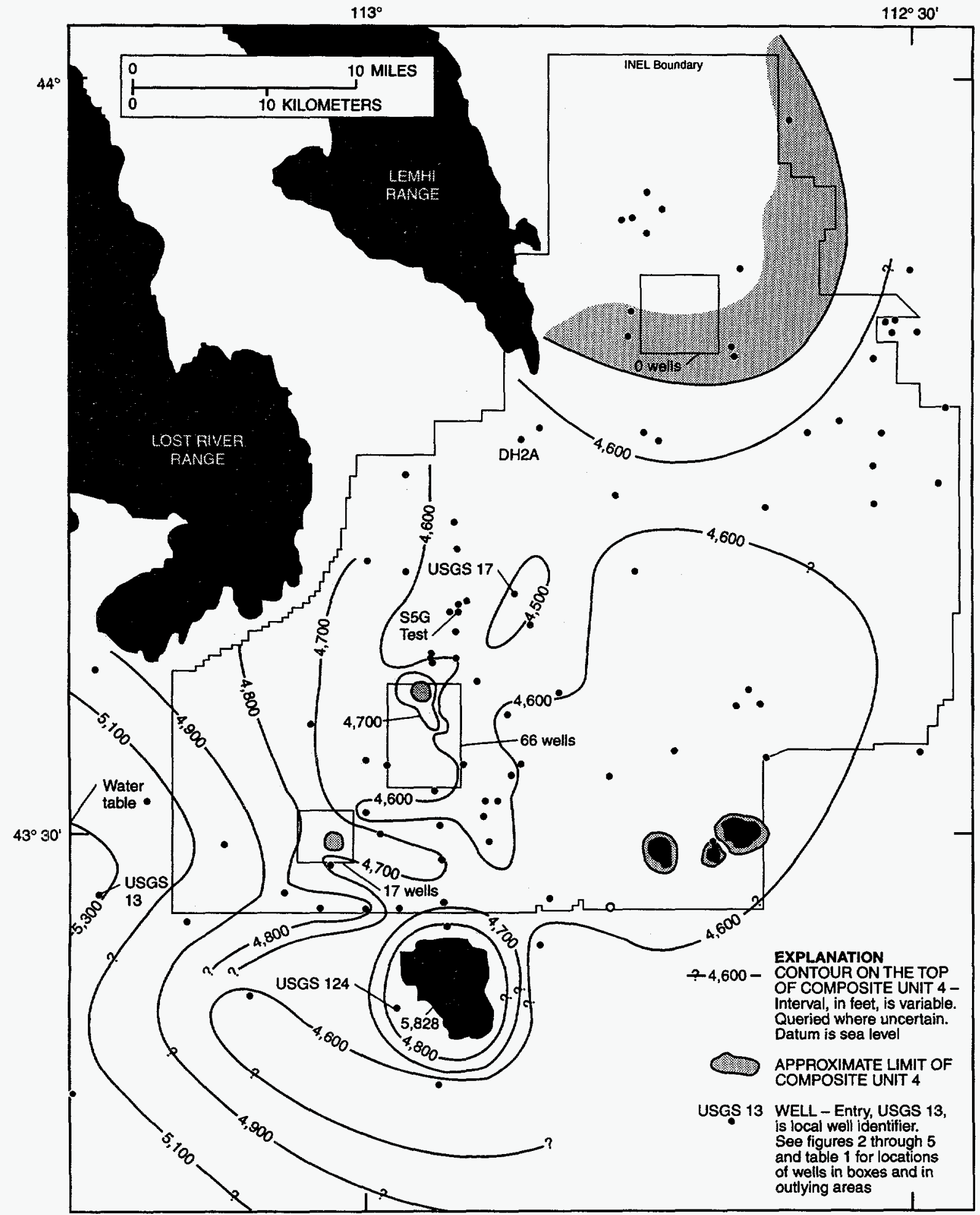

Figure 21. Altitude of the top of composite stratigraphic unit 4 at the Idaho National Engineering Laboratory. 


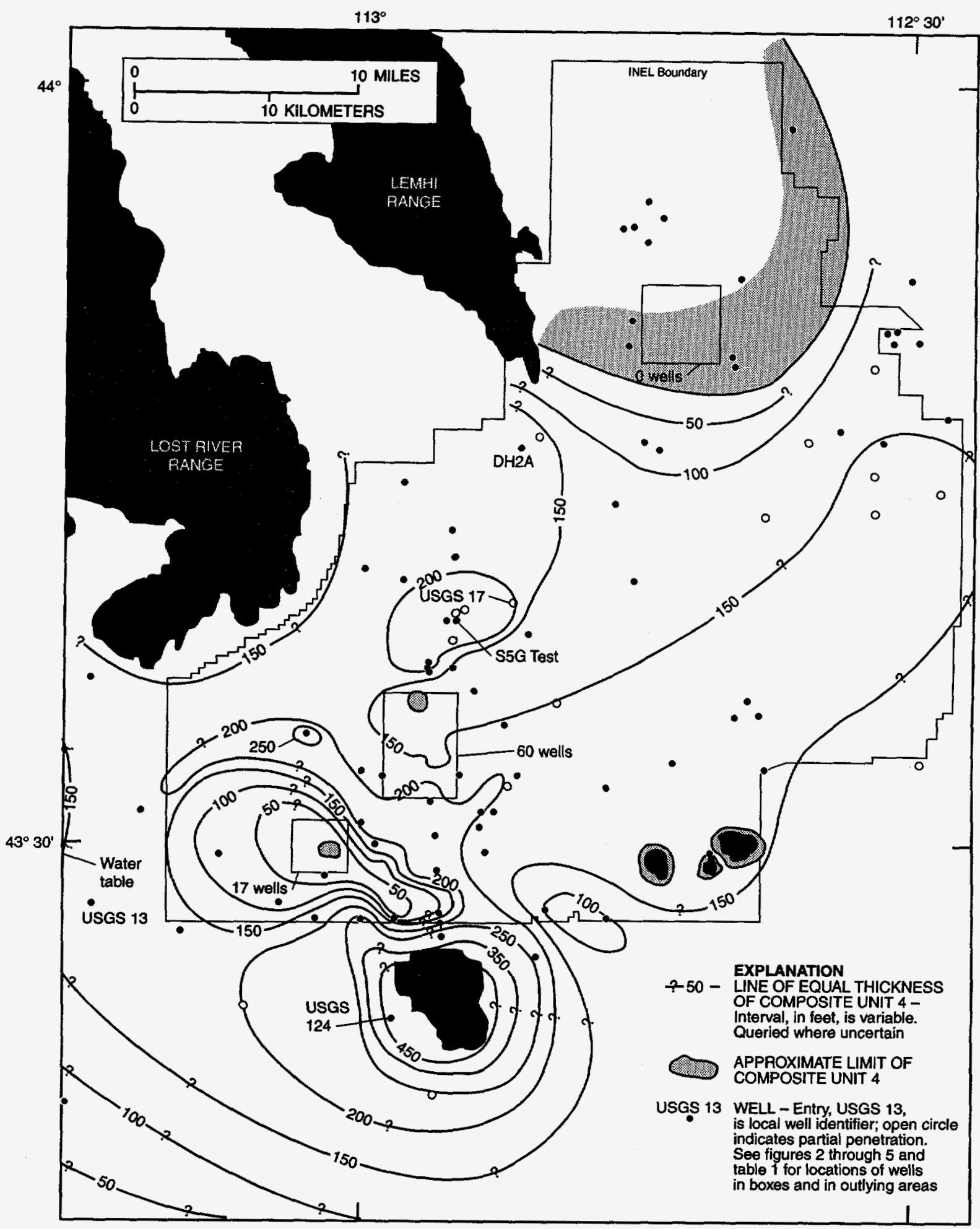

Figure 22. Thickness of composite stratigraphic unit 4 at the Idaho National Engineering Laboratory. 


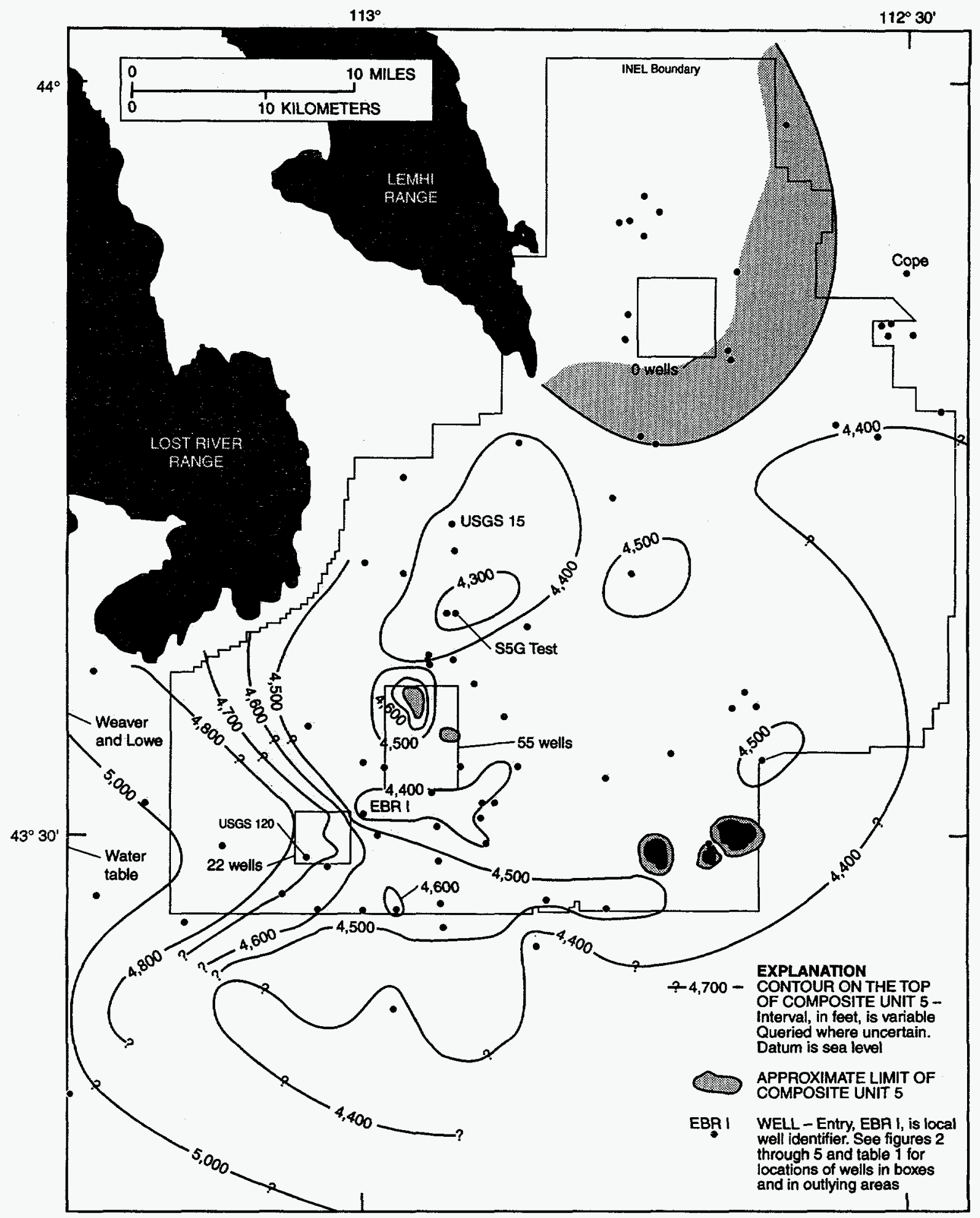

Figure 23. Altitude of the top of composite stratigraphic unit 5 at the Idaho National Engineering Laboratory. 


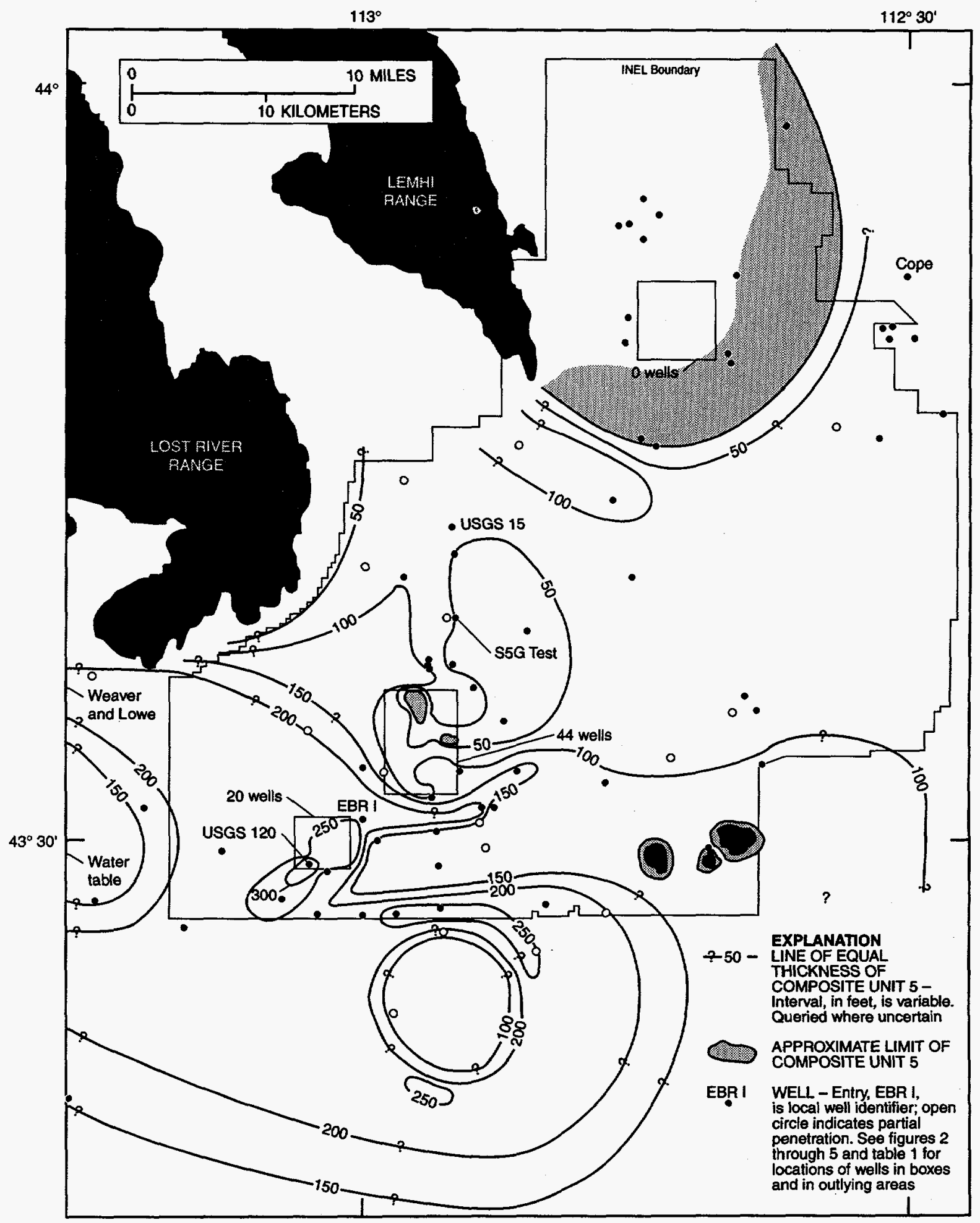

Figure 24. Thickness of composite stratigraphic unit 5 at the Idaho National Engineering Laboratory. 


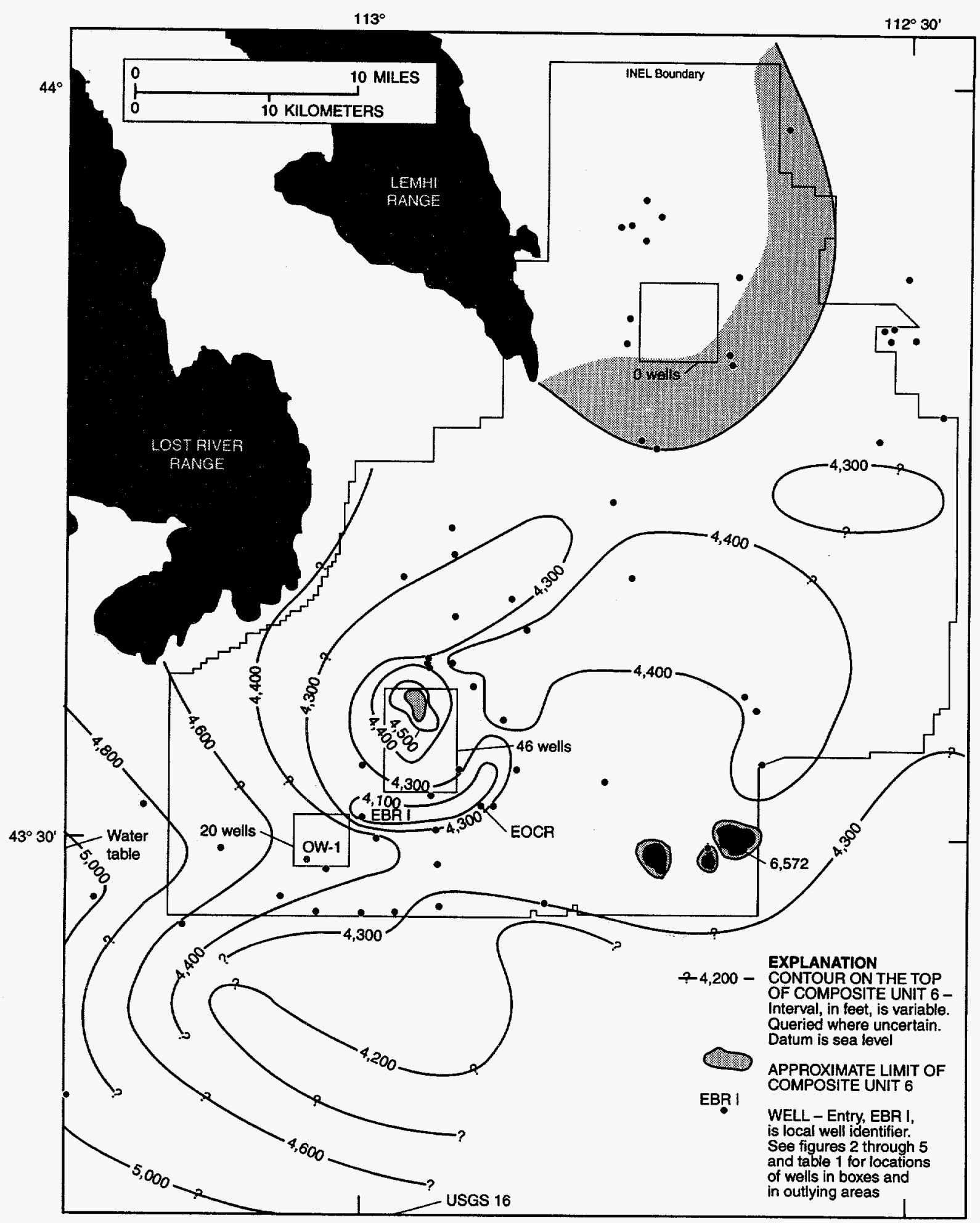

Figure 25. Altitude of the top of composite stratigraphic unit 6 at the Idaho National Engineering Laboratory. 


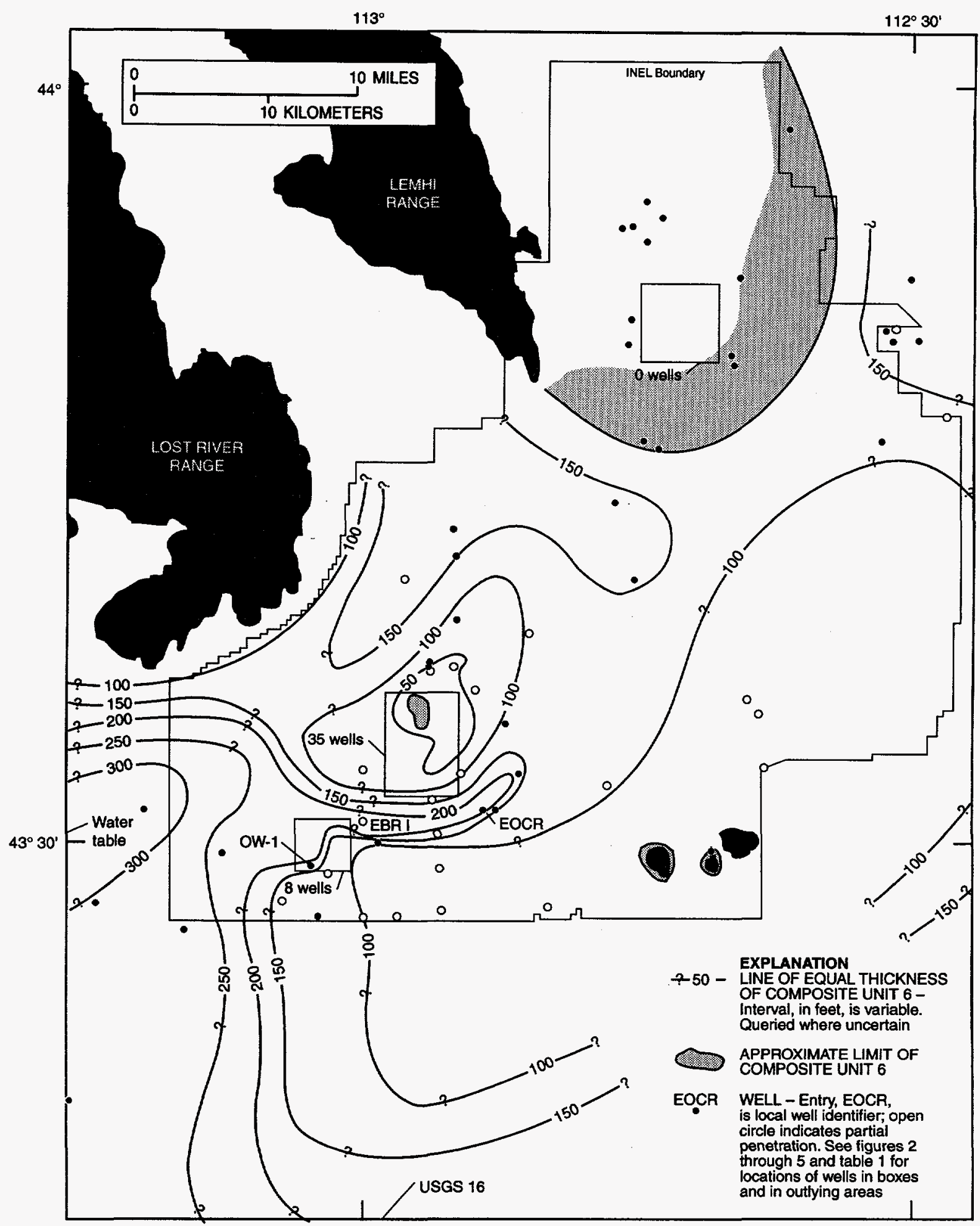

Figure 26. Thickness of composite stratigraphic unit 6 at the Idaho National Engineering Laboratory. 


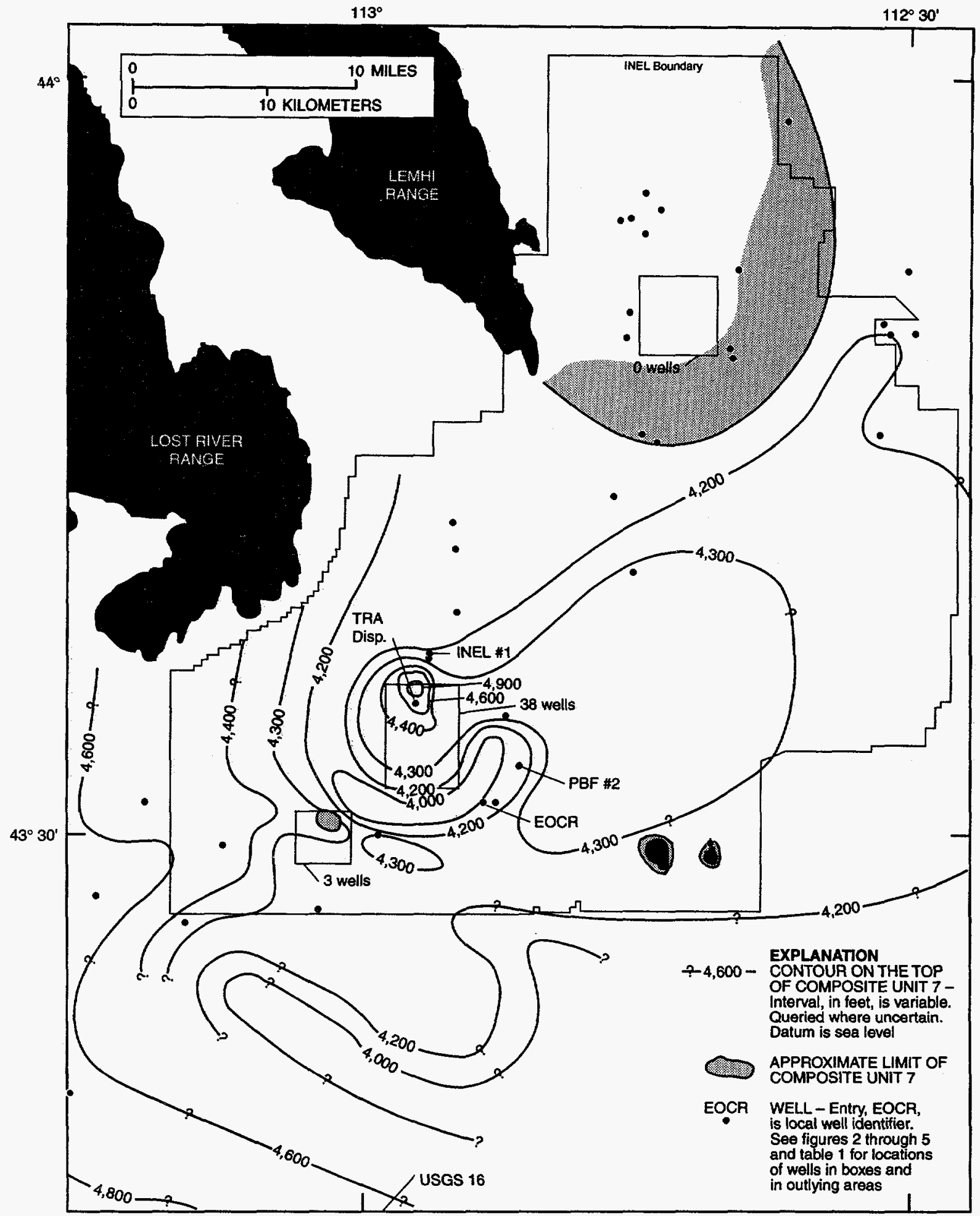

Figure 27. Altitude of the top of composite stratigraphic unit 7 at the Idaho National Engineering Laboratory. 


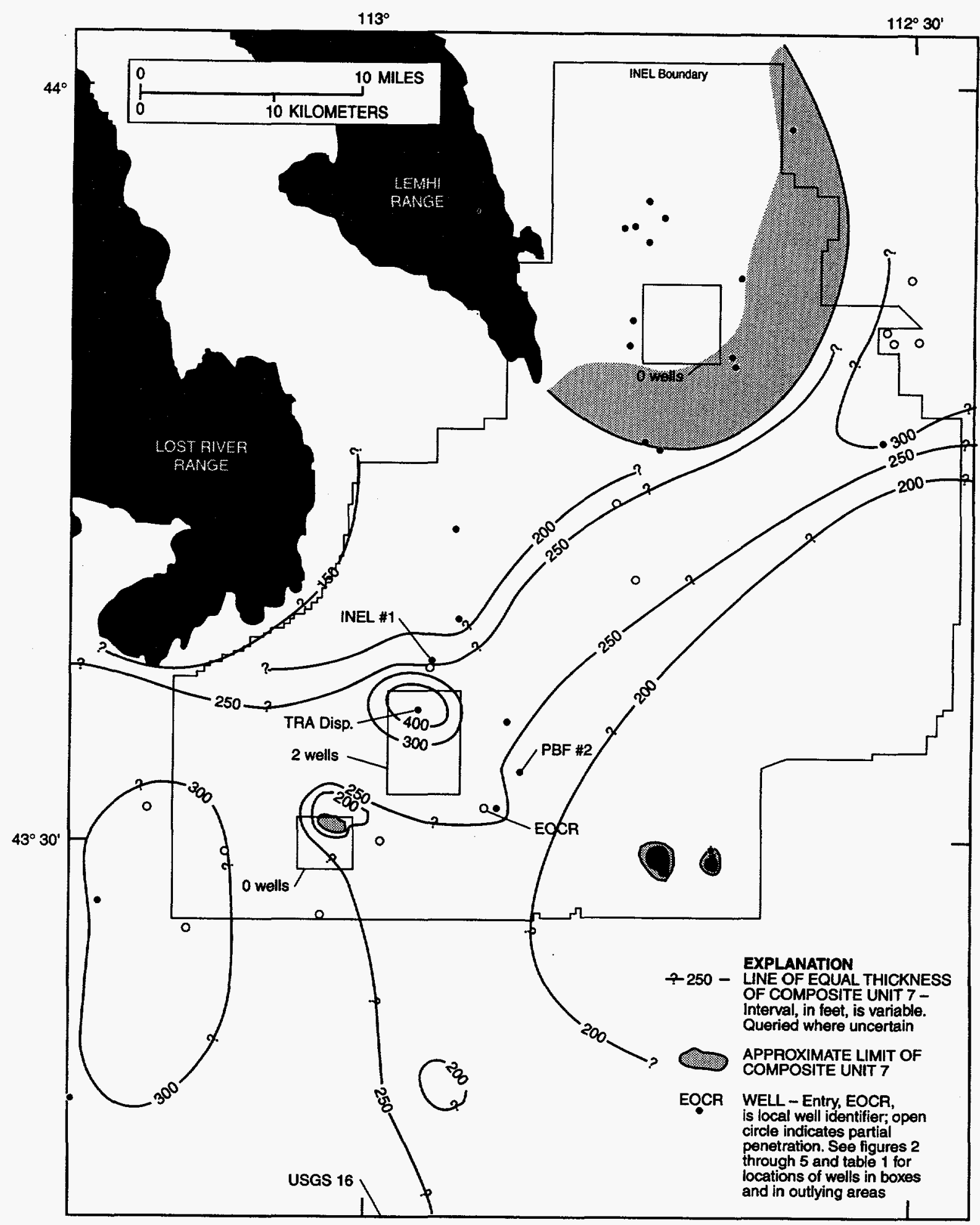

Figure 28. Thickness of composite stratigraphic unit 7 at the Idaho National Engineering Laboratory. 


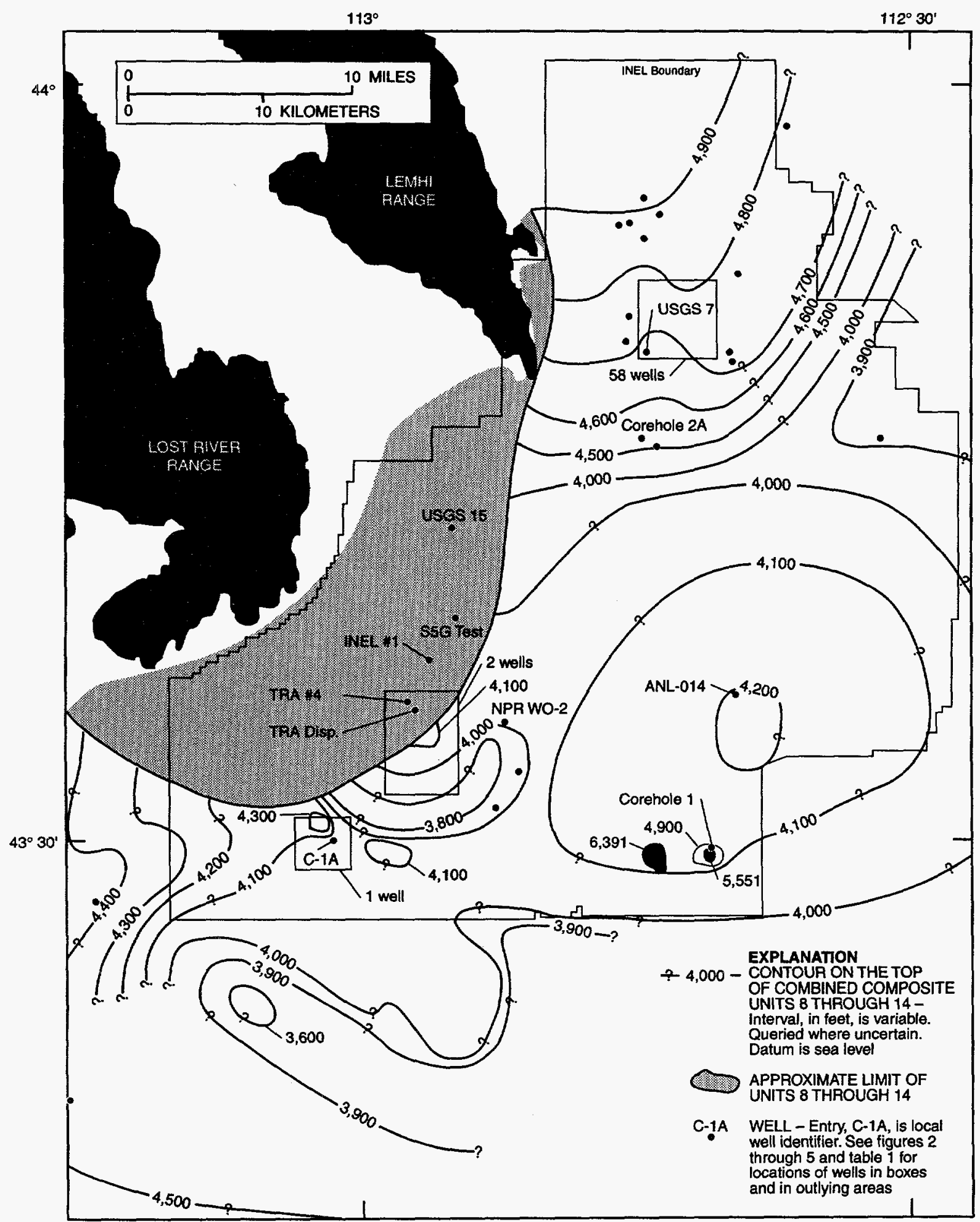

Figure 29. Altitude of the top of combined composite stratigraphic units 8 through 14 at the Idaho National Engineering Laboratory. 


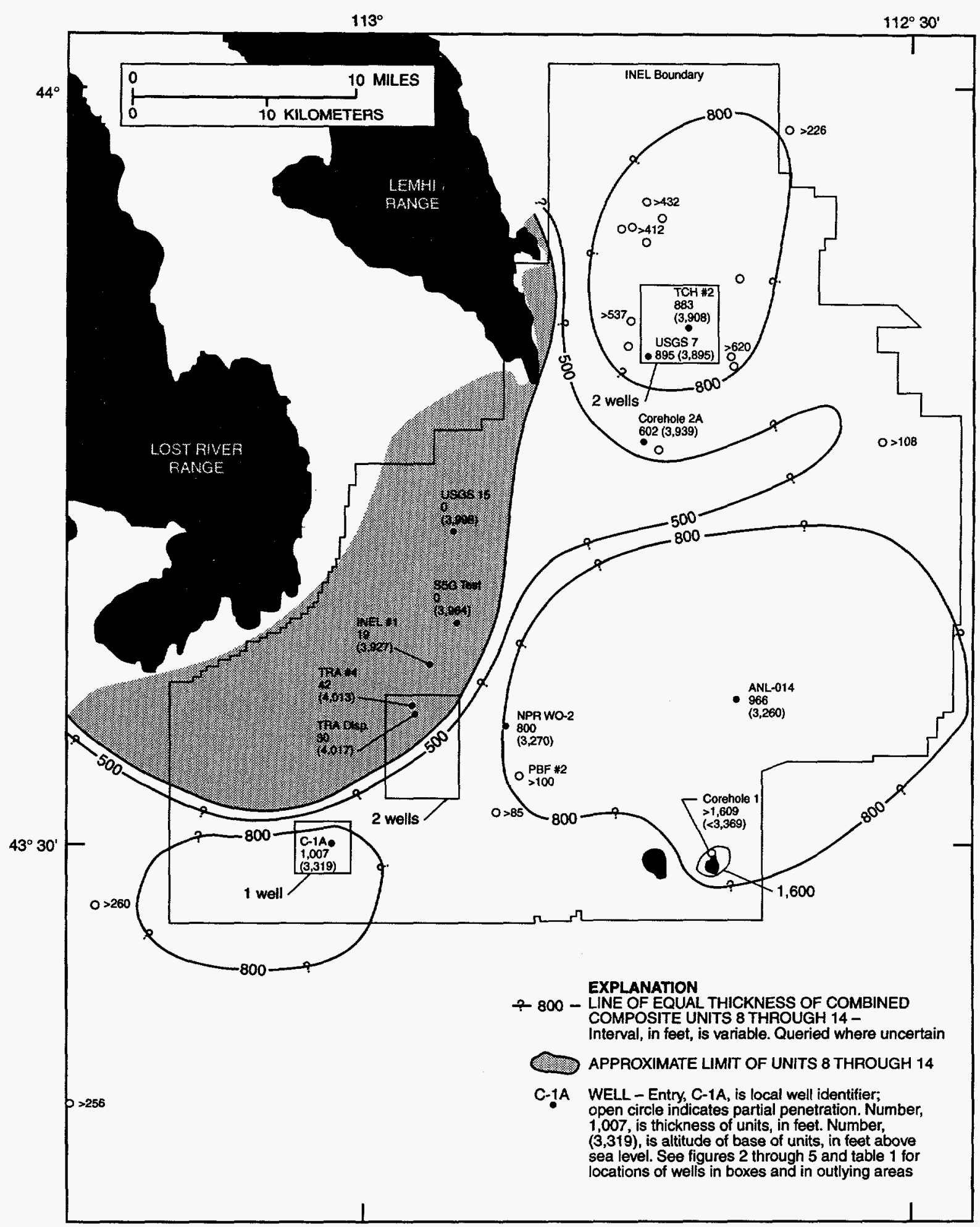

Figure 30. Thickness of combined composite stratigraphic units 8 through 14 at the Idaho National Engineering Laboratory. 
Table 1. Wells at and near the Idaho National Engineering Laboratory for which stratigraphic data are available

[Well: Entry, USGS 1, is a well for which stratigraphic data are available (Anderson and others, 1996a). Figure number indicates the figure number of the map on which a well is located. Map number: Entries, 1 through 335, indicate the map number for each well on figures 2, 3, 4, or 5 and the page number for each well in Anderson and others (1996a, table 6); numbers, 213 and 227 not used. Composite units are composite stratigraphic units in figures 9 through 30 and table 4; commas indicate missing stratigraphic intervals]

\begin{tabular}{|c|c|c|c|c|c|c|c|}
\hline Well identifier & $\begin{array}{l}\text { Figure } \\
\text { number }\end{array}$ & $\begin{array}{c}\text { Map } \\
\text { number }\end{array}$ & $\begin{array}{c}\text { Composite } \\
\text { units }\end{array}$ & Well identifier & $\begin{array}{l}\text { Figure } \\
\text { number }\end{array}$ & $\begin{array}{c}\text { Map } \\
\text { number }\end{array}$ & $\begin{array}{c}\text { Composite } \\
\text { units }\end{array}$ \\
\hline USGS 1 & 2 & 1 & $1-5$ & USGS 43 & 3 & 42 & $1-7$ \\
\hline USGS 2 & 2 & 2 & $1-5$ & USGS 44 & 3 & 43 & $1-7$ \\
\hline USGS 3A & 2 & 3 & $1-3$ & USGS 45 & 3 & 44 & $1-7$ \\
\hline USGS 4 & 2 & 4 & $1,3-6$ & USGS 46 & 3 & 45 & $1-7$ \\
\hline USGS 5 & 2 & 5 & $1-4$ & USGS 47 & 3 & 46 & $1-7$ \\
\hline USGS 6 & 2 & 6 & $1-7$ & USGS 48 & 3 & 47 & $1-7$ \\
\hline USGS 7 & 5 & 7 & $1-3,10-14$ & USGS 49 & 3 & 48 & $1-7$ \\
\hline USGS 8 & 2 & 8 & $1,4-7$ & USGS 50 & 3 & 49 & $1-4$ \\
\hline USGS 9 & 2 & 9 & $1,2-6$ & USGS 51 & 3 & 50 & $1-7$ \\
\hline USGS 11 & 2 & 10 & $1-4$ & USGS 52 & 3 & 51 & $1-4,6-7$ \\
\hline USGS 12 & 2 & 11 & $1-7$ & USGS 53 & 3 & 52 & $1-2$ \\
\hline USGS 13 & 2 & 12 & $1,4-9$ & USGS 54 & 3 & 53 & $1-2$ \\
\hline USGS 14 & 2 & 13 & $1-4$ & USGS 55 & 3 & 54 & $1-2$ \\
\hline USGS 15 & 2 & 14 & $1-7$ & USGS 56 & 3 & 55 & $1-2$ \\
\hline USGS 16 & 2 & 15 & $1,6-9$ & USGS 57 & 3 & 56 & $1-7$ \\
\hline USGS 17 & 2 & 16 & $1-4$ & USGS 58 & 3 & 57 & $1-4,6-7$ \\
\hline USGS 18 & 2 & 17 & $1-4,12$ & USGS 59 & 3 & 58 & $1-7$ \\
\hline USGS 19 & 2 & 18 & $1-5$ & USGS 60 & 3 & 59 & $1-2$ \\
\hline USGS 20 & 2 & 19 & $1-6$ & USGS 61 & 3 & 60 & $1-2$ \\
\hline USGS 21 & 2 & 20 & $1-4$ & USGS 62 & 3 & 61 & $1-3$ \\
\hline USGS 22 & 2 & 21 & $1-5$ & USGS 63 & 3 & 62 & $1-2$ \\
\hline USGS 23 & 2 & 22 & $1-5$ & USGS 64 & 3 & 63 & $1-4$ \\
\hline USGS 24 & 5 & 23 & $1,10,12$ & USGS 65 & 3 & 64 & $1-6$ \\
\hline USGS 25 & 2 & 24 & $1,9-12$ & USGS 66 & 3 & 65 & $1-7$ \\
\hline USGS 26 & 2 & 25 & $1,10-12$ & USGS 67 & 3 & 66 & $1-7$ \\
\hline USGS 27 & 2 & 26 & $1-4$ & USGS 68 & 3 & 67 & $1-2$ \\
\hline USGS 28 & 2 & 27 & $1,3-4$ & USGS 69 & 3 & 68 & $1-2$ \\
\hline USGS 29 & 2 & 28 & $1-4$ & USGS 70 & 3 & 69 & $1,3-4$ \\
\hline USGS 30A & 2 & 29 & $1,3-8$ & USGS 71 & 3 & 70 & $1-3$ \\
\hline USGS 31 & 2 & 30 & $1,3-5$ & USGS 72 & 3 & 71 & $1-3$ \\
\hline USGS 32 & 2 & 31 & $1,3-4$ & USGS 73 & 3 & 72 & $1-2$ \\
\hline USGS 33 & 2 & 32 & $1-4$ & USGS 74 & 3 & 73 & $1-3$ \\
\hline USGS 34 & 3 & 33 & $1-7$ & USGS 75 & 3 & 74 & $1,3-4,7$ \\
\hline USGS 35 & 3 & 34 & $1-6$ & USGS 76 & 3 & 75 & $1-7$ \\
\hline USGS 36 & 3 & 35 & $1-6$ & USGS 77 & 3 & 76 & $1-5$ \\
\hline USGS 37 & 3 & 36 & $1-6$ & USGS 78 & 3 & 77 & $1-3$ \\
\hline USGS 38 & 3 & 37 & $1-7$ & USGS 79 & 3 & 78 & $1-7$ \\
\hline USGS 39 & 3 & 38 & $1-7$ & USGS 80 & 3 & 79 & $1,3-4,7$ \\
\hline USGS 40 & 3 & 39 & $1-7$ & USGS 81 & 3 & 80 & 1-2 \\
\hline USGS 41 & 3 & 40 & $1-7$ & USGS 82 & 3 & 81 & $1-4,6-7$ \\
\hline USGS 42 & 3 & 41 & $1-7$ & USGS 83 & 2 & 82 & $1-6$ \\
\hline
\end{tabular}


Table 1. Wells at and near the Idaho National Engineering Laboratory for which stratigraphic data are available - Continued

\begin{tabular}{|c|c|c|c|c|c|c|c|}
\hline Well identifier & $\begin{array}{l}\text { Figure } \\
\text { number }\end{array}$ & $\begin{array}{c}\text { Map } \\
\text { number }\end{array}$ & $\begin{array}{c}\text { Composite } \\
\text { units }\end{array}$ & Well identifier & $\begin{array}{c}\text { Figure } \\
\text { number }\end{array}$ & $\begin{array}{c}\text { Map } \\
\text { number }\end{array}$ & $\begin{array}{l}\text { Composite } \\
\text { units }\end{array}$ \\
\hline USGS 84 & 3 & 83 & $1-6$ & ANL-IWP-M1 & 2 & 129 & 1 \\
\hline USGS 85 & 3 & 84 & $1-6$ & ANL-IWP-M2 & 2 & 130 & $1-2$ \\
\hline USGS 86 & 2 & 85 & $1,4-7$ & ANL-IWP-M3 & 2 & 131 & 1 \\
\hline USGS 87 & 4 & 86 & $1-2,5-6$ & ANL-IWP-M4 & 2 & 132 & $1-2$ \\
\hline USGS 88 & 4 & 87 & $1-2,4-6$ & ANL-IWP-M5 & 2 & 133 & 1 \\
\hline USGS 89 & 4 & 88 & $1-2,4-6$ & ANL-IWP-M6 & 2 & 134 & $1-3$ \\
\hline USGS 90 & 4 & 89 & $1-2,5-6$ & ANP \#6 & 5 & 135 & $1,9-12$ \\
\hline USGS 91 & 4 & 90 & 1-2 & ANP \#7 & 2 & 136 & $1,8-12$ \\
\hline USGS 92 & 4 & 91 & $1-2$ & ANP \#9 & 2 & 137 & $1-2,10-12$ \\
\hline USGS 93 & 4 & 92 & $1-2$ & ANP \#10 & 2 & 138 & $1-2,10-14$ \\
\hline USGS 93A & 4 & 93 & $1-2$ & AREA II & 2 & 139 & $1-6$ \\
\hline USGS 94 & 4 & 94 & $1-2,4-5$ & Arbor Test 1 & 2 & 140 & $1-6$ \\
\hline USGS 95 & 4 & 95 & 1-2 & R. Archer & 2 & 141 & $1,3-4$ \\
\hline USGS 96 & 4 & 96 & $1-2$ & Ashcraft & 2 & 142 & $1-6$ \\
\hline USGS 96A & 4 & 97 & $1-2$ & BG-76-1 & 4 & 143 & $1-2$ \\
\hline USGS 96B & 4 & 98 & $1-2$ & BG-76-2 & 4 & 144 & $1-2$ \\
\hline USGS 97 & 2 & 99 & $1-4$ & BG-76-3 & 4 & 145 & $1-2$ \\
\hline USGS 98 & 2 & 100 & $1-6$ & BG-76-4 & 4 & 146 & $1-2$ \\
\hline USGS 99 & 2 & 101 & $1-6$ & BG-76-4A & 4 & 147 & $1-2$ \\
\hline USGS 100 & 2 & 102 & $1-5$ & BG-76-5 & 4 & 148 & $1-2$ \\
\hline USGS 101 & 2 & 103 & $1-6$ & BG-76-6 & 4 & 149 & 1-2 \\
\hline USGS 102 & 2 & 104 & $1-4$ & BG-77-1 & 4 & 150 & $1-2,4-6$ \\
\hline USGS 103 & 2 & 105 & $1-6$ & BG-77-2 & 4 & 151 & 1 \\
\hline USGS 104 & 2 & 106 & $1,3-6$ & Barney North & 2 & 152 & $1,3-7$ \\
\hline USGS 105 & 2 & 107 & $1,4-6$ & Barney South & 2 & 153 & $1,3-7$ \\
\hline USGS 106 & 2 & 108 & $1,3-7$ & Butte City \#2 & 2 & 154 & $1-5$ \\
\hline USGS 107 & 2 & 109 & $1-5$ & $\mathrm{C}-1$ & 4 & 155 & $1-2,4-6$ \\
\hline USGS 108 & 2 & 110 & $1-6$ & $\mathrm{C}-1 \mathrm{~A}$ & 4 & 156 & $1-2,4-6,9-12$ \\
\hline USGS 109 & 2 & 111 & $1-2,4-7$ & CFA 1 & 3 & 157 & $1-7$ \\
\hline USGS 110 & 2 & 112 & $1-6$ & CFA 2 & 2 & 158 & $1-6$ \\
\hline USGS 111 & 3 & 113 & $1-5$ & CFA 4 & 2 & 159 & $1-2$ \\
\hline USGS 112 & 3 & 114 & $1-5$ & CFA LF 2-8 & 3 & 160 & $1-5$ \\
\hline USGS 113 & 3 & 115 & $1-5$ & CFA LF 2-9 & 3 & 161 & $1-6$ \\
\hline USGS 114 & 3 & 116 & $1-5$ & CFA LF 2-10 & 3 & 162 & $1-7$ \\
\hline USGS 115 & 3 & 117 & $1-6$ & CFA LF 2-11 & 3 & 163 & $1-5$ \\
\hline USGS 116 & 3 & 118 & $1-6$ & CFA LF 2-12 & 3 & 164 & $1-4$ \\
\hline USGS 117 & 4 & 119 & $1-2,4-6$ & CFA LF 3-8 & 3 & 165 & $1-5$ \\
\hline USGS 118 & 4 & 120 & $1-2,4-6$ & CFA LF 3-9 & 3 & 166 & $1-4$ \\
\hline USGS 119 & 4 & 121 & $1-2,4-6$ & CFA LF 3-10 & 3 & 167 & $1-5$ \\
\hline USGS 120 & 4 & 122 & $1-2,4-6$ & CFA LF 3-11 & 3 & 168 & $1-5$ \\
\hline USGS 121 & 3 & 123 & $1-7$ & CPP 2 & 3 & 169 & $1-7$ \\
\hline USGS 122 & 3 & 124 & $1-5$ & CPP Disp. & 3 & 170 & $1-7$ \\
\hline USGS 123 & 3 & 125 & $1-7$ & CPP 4 & 3 & 171 & $1-7$ \\
\hline USGS 124 & 2 & 126 & $1,4-5$ & Callaway & 2 & 172 & $1,3-7$ \\
\hline $1-27-14$ & 2 & 127 & $1,4-9$ & Cerro Grande & 2 & 173 & $1,4-5$ \\
\hline $\mathrm{A} 11 \mathrm{~A} 31$ & 2 & 128 & $1-2,4-6$ & Cope & 2 & 174 & $1,3-7$ \\
\hline
\end{tabular}


Table 1. Wells at and near the Idaho National Engineering Laboratory for which stratigraphic data are available-Continued

\begin{tabular}{|c|c|c|c|c|c|c|c|}
\hline Well identifier & $\begin{array}{c}\text { Figure } \\
\text { number }\end{array}$ & $\begin{array}{c}\text { Map } \\
\text { number }\end{array}$ & $\begin{array}{c}\text { Composite } \\
\text { units }\end{array}$ & Well identifier & $\begin{array}{c}\text { Figure } \\
\text { number }\end{array}$ & $\begin{array}{c}\text { Map } \\
\text { number }\end{array}$ & $\begin{array}{c}\text { Composite } \\
\text { units }\end{array}$ \\
\hline Corehole 1 & 2 & 175 & $1-2,12$ & NA 89-1 & 2 & 222 & $1-2$ \\
\hline Corehole 2A & 2 & 176 & $1-4,12-14$ & NA 89-2 & 2 & 223 & $1-2$ \\
\hline D-10 & 4 & 177 & $1-2$ & NA 89-3 & 4 & 224 & $1-2$ \\
\hline D-15 & 4 & 178 & $1-2$ & NPR Test & 2 & 225 & $1-7$ \\
\hline DH1B & 2 & 179 & $1-4$ & NPR WO-2 & 2 & 226 & $1-4,6-10$ \\
\hline $\mathrm{DH} 2 \mathrm{~A}$ & 2 & 180 & $1-5$ & NRF \#4 & 2 & 228 & $1-5$ \\
\hline DH3 & 2 & 181 & $1-3$ & NRF \#6 & 2 & 229 & $1-4$ \\
\hline DH-50 & 2 & 182 & $1-2$ & NRF \#6P & 2 & 230 & $1-4$ \\
\hline DO-2 & 4 & 183 & $1-2$ & NRF \#7 & 2 & 231 & $1-4$ \\
\hline DO-6 & 4 & 184 & $1-2$ & NRF \#7P & 2 & 232 & $1-4$ \\
\hline DO-6A & 4 & 185 & 1 & NRF 89-04 & 2 & 233 & $1-3$ \\
\hline Dahle & 2 & 186 & $1,8-12$ & NRF 89-05 & 2 & 234 & $1-3$ \\
\hline EBR I & 2 & 187 & $1-6$ & OW-1 & 4 & 235 & $1-2,4-7$ \\
\hline EFS Well & 2 & 188 & $1-6$ & OW-2 & 4 & 236 & $1-2,4-7$ \\
\hline EOCR & 2 & 189 & $1-7$ & PBF\#2 & 2 & 237 & $1-8$ \\
\hline EOCR (Disp) & 2 & 190 & $1-3$ & PBF (CW) & 2 & 238 & $1-3$ \\
\hline FET-Disp-1 & 5 & 191 & $1,10-12$ & PBF (WW) & 2 & 239 & $1-3$ \\
\hline GIN \#1 & 5 & 192 & $1,10-12$ & PSTF Test & 2 & 240 & $1-2,9-12$ \\
\hline GIN \#2 & 5 & 193 & $1,10-12$ & P \& W \#1 & 2 & 241 & $1,8-12$ \\
\hline GIN \#3 & 5 & 194 & $1,10-12$ & $P \& W \# 2$ & 2 & 242 & $1,8-12$ \\
\hline GIN \#4 & 5 & 195 & $1,10-12$ & $P \& W \# 3$ & 2 & 243 & $1,8-12$ \\
\hline GWN \#5 & 5 & 196 & $1,10-12$ & PW-1 & 3 & 244 & $1-2$ \\
\hline GIN \#6 & 5 & 197 & $1,10-12$ & PW-2 & 3 & 245 & $1-2$ \\
\hline GIN \#7 & 5 & 198 & $1,9-11$ & PW-3 & 3 & 246 & $1-2$ \\
\hline GIN \#8 & 5 & 199 & $1,10-11$ & PW-4 & 3 & 247 & $1-3$ \\
\hline GIN \#9 & 5 & 200 & $1,10-11$ & PW-5 & 3 & 248 & $1-2$ \\
\hline GIN \#10 & 5 & 201 & 1,10 & PW-6 & 3 & 249 & $1-2$ \\
\hline GIN \#11 & 5 & 202 & 1,10 & PW-7 & 3 & 250 & $1-3$ \\
\hline GIN \#12 & 5 & 203 & 1,10 & PW-8 & 3 & 251 & $1-3$ \\
\hline GIN \#13 & 5 & 204 & $1,9-10$ & PW-9 & 3 & 252 & $1-3$ \\
\hline GIN \#14 & 5 & 205 & 1,10 & PW-10 & 3 & 253 & $1-3$ \\
\hline GIN \#15 & 5 & 206 & 1,10 & PW-11 & 3 & 254 & $1-3$ \\
\hline GIN \#16 & 5 & 207 & 1,10 & PW-12 & 3 & 255 & $1-2$ \\
\hline GIN \#17 & 5 & 208 & 1,10 & PW-13 & 3 & 256 & $1-2$ \\
\hline GIN \#18 & 5 & 209 & $1,10-11$ & PW-14 & 3 & 257 & $1-3$ \\
\hline GIN \#19 & 5 & 210 & $1,10-11$ & Quaking Aspen Butte Well & 2 & 258 & $1-2,4-7$ \\
\hline GIN \#20 & 5 & 211 & $1,9-11$ & RWMC-78-1 & 4 & 259 & 1 \\
\hline Highway \#1 Piezo A & 2 & 212 & $1-9$ & RWMC-78-2 & 4 & 260 & $1-2$ \\
\hline Highway \#2 & 2 & 214 & $1-4$ & RWMC-78-3 & 4 & 261 & $1-2$ \\
\hline Highway \#3 & 2 & 215 & $1-6$ & RWMC-78-4 & 4 & 262 & $1-2,4-5$ \\
\hline IET Disp. & 5 & 216 & $1,9-12$ & RWMC-78-5 & 4 & 263 & $1-2$ \\
\hline INEL \#1 & 2 & 217 & $1-8$ & RWMC-79-1 & 4 & 264 & $1-2$ \\
\hline Water Supply for INEL \#1 & 2 & 218 & $1-7$ & RWMC-79-2 & 4 & 265 & $1-2$ \\
\hline LPTF Disposal & 5 & 219 & $1,10-12$ & RWMC-79-3 & 4 & 266 & $1-2$ \\
\hline MTR Test & 3 & 220 & $1-5,7$ & RWMC-88-1D & 4 & 267 & $1-2$ \\
\hline Main Gate Well & 2 & 221 & $1-5$ & RWMC-88-02D & 4 & 268 & $1-2$ \\
\hline
\end{tabular}


Table 1. Wells at and near the Idaho National Engineering Laboratory for which stratigraphic data are available-Continued

\begin{tabular}{|c|c|c|c|c|c|c|c|}
\hline Well identifier & $\begin{array}{c}\text { Figure } \\
\text { number }\end{array}$ & $\begin{array}{c}\text { Map } \\
\text { number }\end{array}$ & $\begin{array}{l}\text { Composite } \\
\text { units }\end{array}$ & Well identifier & $\begin{array}{c}\text { Figure } \\
\text { number }\end{array}$ & $\begin{array}{c}\text { Map } \\
\text { number }\end{array}$ & $\begin{array}{l}\text { Composite } \\
\text { units }\end{array}$ \\
\hline RWMC-89-01D & 4 & 269 & $1-2$ & $\overline{\mathrm{TAN} \# 14}$ & 5 & 303 & $1,10-12$ \\
\hline RWMC M1SA & 4 & 270 & $1-2,4-6$ & TAN \#15 & 5 & 304 & $1,9-10,12$ \\
\hline RWMC M3S & 4 & 271 & $1-2,5-6$ & TAN \#16 & 5 & 305 & $1,9-10,12$ \\
\hline RWMC M4D & 4 & 272 & $1-2,4-7$ & TAN \#17 & 5 & 306 & $1,10,12$ \\
\hline RWMC M6S & 4 & 273 & $1-2,5-6$ & TAN \#18 & 5 & 307 & $1,10,12-13$ \\
\hline RWMC M7S & 4 & 274 & $1-2,4-6$ & TAN \#19 & 5 & 308 & $1,10,12$ \\
\hline RWMC M10S & 4 & 275 & $1-2,4-6$ & TAN \#20 & 5 & 309 & $1,10-12$ \\
\hline RWMC Prod. & 4 & 276 & $1-2,5-6$ & TAN \#21 & 5 & 310 & $1,10-13$ \\
\hline Rifle Range Well & 2 & 277 & $1-5$ & TAN \#22 & 5 & 311 & $1,9-10,12-13$ \\
\hline Leo Roger's \#1 & 2 & 278 & $1-5$ & TAN \#22A & 5 & 312 & $1,9-10,12-13$ \\
\hline S5G Test (NRF \#5) & 2 & 279 & $1-7$ & TAN \#23 & 5 & 313 & $1,9-10,12-13$ \\
\hline Sdd-1 & 2 & 280 & $1-3$ & TAN \#23A & 5 & 314 & $1,9-10,12$ \\
\hline Sdd-2 & 2 & 281 & $1-4$ & TAN \#24 & 5 & 315 & $1,9-12$ \\
\hline Sdd-3 & 2 & 282 & $1-3$ & TAN \#24A & 5 & 316 & $1,9-12$ \\
\hline Siddoway & 2 & 283 & $1,3-7$ & TAN Drainage Disp.\#1 & 5 & 317 & $1,10-12$ \\
\hline Site 6 & 2 & 284 & $1-6$ & TAN Drainage Disp.\#2 & 5 & 318 & $1,10,12$ \\
\hline Site 9 & 2 & 285 & $1-8$ & TAN Drainage Disp.\#3 & 5 & 319 & $1,10,12$ \\
\hline Site 14 & 2 & 286 & $1-7$ & TAN Exploratory Well & 2 & 320 & $1,9-13$ \\
\hline Site 16 & 2 & 287 & $1-6$ & TCH \#1 & 5 & 321 & $1,10-14$ \\
\hline Site 17 & 2 & 288 & $1-6$ & TCH \#2 Piezo A & 5 & 322 & $1,10-14$ \\
\hline Site 19 & 3 & 289 & $1-7$ & TRA \#3 & 3 & 323 & $1-7$ \\
\hline TAN \#3 & 5 & 290 & $1,10-12$ & TRA \#4 & 3 & 324 & $1-8$ \\
\hline TAN \#4 & 5 & 291 & 1,12 & TRA 05/PZ1 & 3 & 325 & $1-4$ \\
\hline TAN \#5 & 5 & 292 & $1,10,12$ & TRA 06A & 3 & 326 & $1-7$ \\
\hline TAN \#6 & 5 & 293 & $1,10,12$ & TRA 07 & 3 & 327 & $1-6$ \\
\hline TAN\#7 & 5 & 294 & $1,10,12$ & TRA 08 & 3 & 328 & $1-6$ \\
\hline TAN \#8 & 5 & 295 & $1,9-10,12$ & TRA Disp. & 3 & 329 & $1-8$ \\
\hline TAN \#9 & 5 & 296 & $1,10,12$ & TW-1 & 4 & 330 & $1-2$ \\
\hline TAN \#10 & 5 & 297 & $1,10-12$ & VZT-1 & 4 & 331 & $1-2$ \\
\hline TAN\#10A & 5 & 298 & $1,10-12$ & WWW\#1 & 4 & 332 & $1-2$ \\
\hline TAN \#11 & 5 & 299 & $1,10-12$ & WWW\#2 & 4 & 333 & 1 \\
\hline TAN\#12 & 5 & 300 & $1,10-12$ & Water table & 2 & 334 & $1,4-9$ \\
\hline TAN \#13 & 5 & 301 & $1,10-12$ & Weaver and Lowe & 2 & 335 & $1-2,4-9$ \\
\hline TAN \#13A & 5 & 302 & $1,10-12$ & & & & \\
\hline
\end{tabular}


Table 2. Selected cores and sources of data used to evaluate stratigraphic units underlying the Idaho National Engineering Laboratory

[Well is one from which continuous core was obtained; core locations shown in figure 6. Depth is total depth of well and approximate total depth of core, in feet below land surface. Data include paleomagnetic inclination and polarity, K-Ar (potassium-argon) and ${ }^{40} \mathrm{Ar} /{ }^{39} \mathrm{Ar}$ (argon-argon) ages, petrographic descriptions, and major-oxide and trace element chemistry. Symbol: -- indicates no data. Numbers in columns 3-6 indicate the following data references: $1=$ Kuntz and others (1980); $2=$ Champion and others (1988); 3 = Lanphere and others (1993); 4 = Lanphere and others (1994); $5=$ Knobel and others (1995); 6 $=$ Reed and others (1997); 7 = Duane E. Champion, USGS, written commun., 1989-95; 8 = Marvin A. Lanphere, USGS, written commun., 1989-95; 9 = Mel A. Kuntz, USGS, written commun., 1989-95; and 10 = Roy C. Bartholomay, written commun., 1989-95. Additional data for deposits in and underlying the Snake River Plain aquifer are indicated by the following references: $11=$ Shervais and others, 1994; 12 = Lawrence and Hackett, 1994; and 13 = Hackett and others, 1994]

\begin{tabular}{|c|c|c|c|c|c|}
\hline $\begin{array}{l}\text { Well and core } \\
\text { identifier }\end{array}$ & $\begin{array}{l}\text { Depth } \\
\text { (feet) }\end{array}$ & $\begin{array}{c}\text { Source of } \\
\text { paleomagnetic data }\end{array}$ & $\begin{array}{c}\text { Source of } \\
\text { geochronologic } \\
\text { data }\end{array}$ & $\begin{array}{c}\text { Source of } \\
\text { petrographic data }\end{array}$ & $\begin{array}{c}\text { Source of chemical } \\
\text { data }\end{array}$ \\
\hline BG-76-1 & 228 & 1 & 1 & 1 & - \\
\hline BG-77-1 & 600 & 1 & 1,2 & 1 & 10 \\
\hline C-1A & 1,805 & 7 & 8 & -- & -- \\
\hline Corehole 1 & 2,002 & 7 & -- & -- & -- \\
\hline Corehole 2A & 3,000 & 7 & 8 & -- & -. \\
\hline DH-50 & 250 & 7 & --- & -- & -- \\
\hline GIN \#5 & 430 & 4 & -- & -- & -- \\
\hline GIN \#6 & 200 & 4 & -- & -. & -- \\
\hline NPR Test & 609 & 2 & 2 & -- & $5,10,11$ \\
\hline NPR WO-2 & 5,000 & 7,13 & 8,13 & 12 & 11 \\
\hline NRF \#6P & 500 & 7 & -- & -- & -. \\
\hline NRF \#7P & 500 & 7 & 8 & -- & -- \\
\hline NRF 89-04 & 248 & 3 & 3 & -- & - \\
\hline NRF 89-05 & 242 & 3 & 3 & 3 & - \\
\hline PW-13 & 148 & 7 & -- & -- & -- \\
\hline TCH \#1 & 600 & 4 & 4 & 4 & 5 \\
\hline TCH \#2 Piezo A & 1,114 & 4 & 4 & 4 & 5 \\
\hline TRA 05/PZ1 & 297 & 7 & 8 & -- & 5 \\
\hline USGS 80 & 204 & 3 & 3 & 3 & -- \\
\hline USGS 81 & 108 & 7 & - & -- & -- \\
\hline USGS 93A & 233 & -- & -- & 1 & -- \\
\hline USGS 94 & 302 & 1 & 1 & 1 & -- \\
\hline USGS 118 & 570 & 7 & -- & -- & 10 \\
\hline USGS 121 & 746 & 7 & 8 & 9 & 6 \\
\hline USGS 123 & 744 & 3 & 3 & 3 & 6 \\
\hline WWW \#1 & 265 & 7 & -- & -- & -- \\
\hline
\end{tabular}


Table 3. Wells that penetrate the effective base of the Snake River Plain aquifer at the Idaho National Engineering Laboratory

[Depth is total depth of well, in feet below land surface. Base is the depth to the effective base of the Snake River Plain aquifer, in feet below land surface. Saturated thickness is approximate saturated thickness of aquifer, in feet, based on 1990 water levels from these or nearby wells (Ott and others, 1992). Lithology indicates the relative abundance of basalt (B) and sediment (S) below the base of the aquifer to a depth of 500 feet; greatest abundance is listed first. Core indicates the availability of continuous core (table 2)]

\begin{tabular}{lccccc}
\hline Well identifier & Depth (feet) & Base (feet) & $\begin{array}{c}\text { Saturated } \\
\text { thickness (feet) }\end{array}$ & Lithology & Core \\
\hline C-1A & 1,805 & 1,710 & 1,120 & B, S & Yes \\
Corehole 2A & 3,000 & 846 & 580 & S, B & Yes \\
INEL \#1 & 10,365 & 965 & 660 & S, B & No \\
NPR WO-2 & 5,000 & 1,660 & 1,200 & B, S & Yes \\
S5G TEST & 1,276 & 884 & 515 & B, S & No \\
TCH \#2 & 1,114 & 883 & 680 & B, S & Yes \\
TRA \#4 & 970 & 909 & 445 & B, S & No \\
TRA Disp & 1,275 & 907 & 445 & B, S & No \\
USGS 7 & 1,200 & 895 & 685 & B, S & No \\
USGS 15 & 1,497 & 815 & 500 & S, B & No \\
\hline
\end{tabular}


Table 4. Stratigraphic units on or underlying the Idaho National Engineering Laboratory and adjacent areas

[Stratigraphic unit is a volcanic or sedimentary unit from Anderson and others (1996a); units listed from youngest, $\mathrm{Au}(1)$, to oldest, S5(1). Composite unit is a composite stratigraphic unit in figures 9 through 30 and table 1 ; bold type indicates first entry of a composite unit. Lithologic type indicates the following generalized lithologic types: Bas = basalt; Sed = sediment; And = Andesite; and Rhy = rhyolite; basalt, andesite, and rhyolite are flow groups that consist of one or more flows from a single eruptive event. Vent number indicates the location of a volcanic vent in figure 7. Wells indicates the number of wells in which each stratigraphic unit is present]

\begin{tabular}{|c|c|c|c|c|c|c|c|c|c|}
\hline $\begin{array}{l}\text { Stratigraphic } \\
\text { unit }\end{array}$ & $\begin{array}{c}\text { Composite } \\
\text { unit }\end{array}$ & $\begin{array}{c}\text { Lithologic } \\
\text { type }\end{array}$ & $\begin{array}{c}\text { Vent } \\
\text { number }\end{array}$ & Wells & $\begin{array}{c}\text { Stratigraphic } \\
\text { unit }\end{array}$ & $\begin{array}{c}\text { Composite } \\
\text { unit }\end{array}$ & $\begin{array}{c}\text { Lithologic } \\
\text { type }\end{array}$ & $\begin{array}{c}\text { Vent } \\
\text { number }\end{array}$ & Wells \\
\hline $\mathbf{A u}(\mathbf{1})$ & 1 & Sed & & 0 & $\mathrm{AB}(12)$ & 1 & Bas & 27 & 1 \\
\hline $\mathrm{Au}(2)$ & 1 & Bas & 1 & 0 & $\mathrm{AB}(13)$ & 1 & Bas & 28 & 2 \\
\hline $\mathrm{Au}(3)$ & 1 & Bas & 2 & 0 & $\mathrm{AB}(14)$ & 1 & Bas & 29 & 0 \\
\hline $\mathrm{Au}(4)$ & 1 & Bas & 3 & 0 & $\mathrm{AB}(15)$ & 1 & Bas & 30 & 0 \\
\hline $\mathrm{Au}(5)$ & 1 & Bas & 4 & 0 & $\mathrm{AB}(16)$ & 1 & Bas & 31 & 1 \\
\hline $\mathrm{Al}(1)$ & 1 & Sed & & 288 & $\mathrm{AB}(17)$ & 1 & Bas & 32 & 0 \\
\hline $\mathrm{Al}(2)$ & 1 & Bas & 5 & 0 & $\mathrm{AB}(17)$ & 1 & Sed & & 1 \\
\hline $\operatorname{Al}(3)$ & 1 & Bas & 6 & 2 & $\mathrm{AB}(18)$ & 1 & Bas & 33 & 1 \\
\hline $\mathrm{Al}(4)$ & 1 & Bas & 7 & 0 & $\mathrm{AB}(18)$ & 1 & Sed & & 1 \\
\hline $\mathrm{Al}(5)$ & 1 & Bas & 8 & 2 & $\mathrm{AB}(19)$ & 1 & Bas & 34 & 0 \\
\hline $\mathrm{Al}(6)$ & 1 & Bas & 9 & 1 & $\mathrm{AB}(20)$ & 1 & Bas & 35 & 0 \\
\hline $\mathrm{Al}(7)$ & 1 & Bas & 10 & 0 & $\mathrm{AB}(21)$ & 1 & Bas & 36 & 0 \\
\hline $\operatorname{Al}(8)$ & 1 & Bas & 11 & 0 & $\mathrm{AB}(22)$ & 1 & Bas & 37 & 1 \\
\hline $\operatorname{Al}(9)$ & 1 & Bas & 12 & 34 & $\mathrm{AB}(23)$ & 1 & Bas & 38 & 1 \\
\hline $\operatorname{Al}(9)$ & 1 & Sed & & 12 & $\mathrm{AB}(24)$ & 1 & Bas & 39 & 0 \\
\hline $\operatorname{Al}(10)$ & 1 & Bas & 13 & 0 & $\mathrm{AB}(25)$ & 1 & Bas & 40 & 0 \\
\hline $\mathrm{Al}(11)$ & 1 & Bas & 14 & 0 & $\mathrm{AB}(26)$ & 1 & Bas & 41 & 1 \\
\hline $\operatorname{Al}(12)$ & 1 & Bas & 15 & 0 & $\mathrm{AB}(27)$ & 1 & Bas & 42 & 0 \\
\hline $\operatorname{Al}(13)$ & 1 & Bas & 16 & 0 & $\mathrm{AB}(28)$ & 1 & Bas & 43 & 1 \\
\hline $\mathrm{AB}(1)$ & 1 & Sed & & 211 & $\mathrm{AB}(29)$ & 1 & Bas & 44 & 0 \\
\hline $\mathrm{AB}(2)$ & 1 & Bas & 17 & 0 & $\mathrm{AB}(30)$ & 1 & Bas & 45 & 1 \\
\hline $\mathrm{AB}(3)$ & 1 & Bas & 18 & 0 & $\mathrm{AB}(31)$ & 1 & Bas & 46 & 2 \\
\hline $\mathrm{AB}(4)$ & 1 & Bas & 19 & 0 & $\mathrm{AB}(32)$ & 1 & Bas & 47 & 0 \\
\hline $\mathrm{AB}(5)$ & 1 & Bas & 20 & 0 & $\mathrm{AB}(33)$ & 1 & Bas & 48 & 0 \\
\hline $\mathrm{AB}(6)$ & 1 & Bas & 21 & 0 & $\mathrm{AB}(34)$ & 1 & Bas & 49 & 0 \\
\hline $\mathrm{AB}(7)$ & 1 & Bas & 22 & 0 & $A B(35)$ & 1 & Bas & 50 & 0 \\
\hline $\mathrm{AB}(8)$ & 1 & Bas & 23 & 3 & $\mathrm{AB}(36)$ & 1 & Bas & 51 & 0 \\
\hline $\mathrm{AB}(9)$ & 1 & Bas & 24 & 12 & $\mathrm{AB}(37)$ & 1 & Bas & 52 & 0 \\
\hline $\mathrm{AB}(10)$ & 1 & Bas & 25 & 9 & $\mathrm{AB}(38)$ & 1 & Bas & 53 & 0 \\
\hline $\mathrm{AB}(11)$ & 1 & Bas & 26 & 8 & $\mathrm{AB}(39)$ & 1 & Bas & 54 & 0 \\
\hline $\mathrm{AB}(11)$ & 1 & Sed & & 11 & $\mathrm{AB}(40)$ & 1 & Bas & 55 & 0 \\
\hline
\end{tabular}


Table 4. Stratigraphic units on or underlying the Idaho National Engineering Laboratory and adjacent areas - Continued

\begin{tabular}{|c|c|c|c|c|c|c|c|c|c|}
\hline $\begin{array}{l}\text { Stratigraphic } \\
\text { unit }\end{array}$ & $\begin{array}{c}\text { Composite } \\
\text { unit }\end{array}$ & $\begin{array}{l}\text { Lithologic } \\
\text { type }\end{array}$ & $\begin{array}{c}\text { Vent } \\
\text { number }\end{array}$ & Wells & $\begin{array}{c}\text { Stratigraphic } \\
\text { unit }\end{array}$ & $\begin{array}{c}\text { Composite } \\
\text { unit }\end{array}$ & $\begin{array}{l}\text { Lithologic } \\
\text { type }\end{array}$ & $\begin{array}{c}\text { Vent } \\
\text { number }\end{array}$ & Wells \\
\hline $\mathrm{AB}(41)$ & 1 & Bas & 56 & 0 & $\mathrm{BC}(4)$ & 2 & Bas & 82 & 2 \\
\hline $\mathrm{AB}(42)$ & 1 & Bas & 57 & 0 & $\mathrm{C}(1)$ & 2 & Bas & 83 & 131 \\
\hline $\mathrm{AB}(43)$ & 1 & Bas & 58 & 0 & $C(1)$ & 2 & Sed & & 13 \\
\hline $\mathrm{AB}(44)$ & 1 & Bas & 59 & 0 & $\mathrm{CD}(1)$ & 2 & Bas & 84 & 31 \\
\hline $\mathrm{AB}(45)$ & 1 & Bas & 60 & 0 & $\mathrm{CD}(1)$ & 2 & Sed & & 76 \\
\hline $\mathrm{AB}(46)$ & 1 & Bas & 61 & 0 & $\mathrm{CD}(2)$ & 2 & Bas & 85 & 4 \\
\hline $\mathrm{AB}(47)$ & 1 & Bas & 62 & 1 & $D(1)$ & 2 & Bas & 86 & 95 \\
\hline $\mathrm{AB}(48)$ & 1 & Bas & 63 & 0 & $\mathrm{D}(1)$ & 2 & Sed & & 9 \\
\hline $\mathrm{AB}(49)$ & 1 & Bas & 64 & 1 & $\mathrm{D}(2)$ & 2 & Bas & 87 & 2 \\
\hline $\mathrm{AB}(50)$ & 1 & Bas & 65 & 0 & $\mathrm{D}(2)$ & 2 & Sed & & 3 \\
\hline $\mathrm{AB}(51)$ & 1 & Bas & 66 & 2 & $D(3)$ & 2 & Bas & 88 & 6 \\
\hline $\mathrm{AB}(52)$ & 1 & Bas & 67 & 0 & $\mathrm{D}(4)$ & 2 & Bas & 89 & 11 \\
\hline $\mathrm{AB}(53)$ & 1 & Bas & 68 & 1 & DE1(1) & 2 & Bas & 90 & 5 \\
\hline $\mathrm{AB}(54)$ & 1 & Bas & 69 & 0 & $\mathrm{DE} 1(1)$ & 2 & Sed & & 2 \\
\hline $\mathrm{AB}(55)$ & 1 & Bas & 70 & 0 & DE1(2) & 2 & Bas & 91 & 10 \\
\hline $\mathrm{AB}(56)$ & 1 & Bas & 71 & 0 & DE1(3) & 2 & Bas & 92 & 57 \\
\hline $\mathrm{AB}(57)$ & 1 & Bas & 72 & 0 & DE1(3) & 2 & Sed & & 10 \\
\hline $\mathrm{AB}(58)$ & 1 & Bas & 73 & 0 & DE1(4) & 2 & Bas & 93 & 4 \\
\hline$B(1)$ & 1 & Bas & 74 & 143 & DE1(4) & 2 & Rhy & 94 & 0 \\
\hline$B(1)$ & 1 & Sed & & 85 & DE1(4) & 2 & Sed & & 2 \\
\hline B-BC(1) & 1 & Bas & 75 & 6 & $\mathrm{DE} 1-2(1)$ & 2 & Bas & 95 & 28 \\
\hline $\mathrm{B}-\mathrm{BC}(1)$ & 1 & Sed & & 5 & DE1-2(1) & 2 & Sed & & 37 \\
\hline $\mathrm{B}-\mathrm{BC}(2)$ & 1 & Bas & 76 & 10 & DE1-2(2) & 2 & Bas & 96 & 2 \\
\hline $\mathrm{B}-\mathrm{BC}(2)$ & 1 & Sed & & 161 & DE1-2(2) & 2 & Sed & & 11 \\
\hline $\mathrm{B}-\mathrm{BC}(3)$ & 1 & Bas & 77 & 32 & DE1-2(3) & 2 & Bas & 97 & 1 \\
\hline $\mathrm{B}-\mathrm{BC}(3)$ & 1 & Sed & & 2 & DE1-2(3) & 2 & Sed & & 1 \\
\hline $\mathrm{B}-\mathrm{BC}(4)$ & 1 & Bas & 78 & 2 & DE2(1) & 3 & Bas & $98 \mathbf{a}, \mathbf{b}$ & 103 \\
\hline $\mathrm{B}-\mathrm{BC}(4)$ & 1 & Sed & & 5 & $\mathrm{DE} 2(1)$ & 3 & Sed & & 42 \\
\hline $\mathrm{BC}(1)$ & 2 & Bas & 79 & 101 & DE2-3(1) & 3 & Bas & 99 & 24 \\
\hline $\mathrm{BC}(1)$ & 2 & Sed & & 27 & DE2-3(1) & 3 & Sed & & 67 \\
\hline $\mathrm{BC}(2)$ & 2 & Bas & 80 & 79 & DE2-3(2) & 3 & Bas & 100 & 10 \\
\hline $\mathrm{BC}(2)$ & 2 & Sed & & 10 & $\mathrm{DE} 2-3(2)$ & 3 & Sed & & 10 \\
\hline $\mathrm{BC}(3)$ & 2 & Bas & 81 & 11 & DE2-3(3) & 3 & Bas & 101 & 1 \\
\hline $\mathrm{BC}(3)$ & 2 & Sed & & 42 & DE3(1) & 3 & Bas & 102 & 118 \\
\hline
\end{tabular}


Table 4. Stratigraphic units on or underlying the Idaho National Engineering Laboratory and adjacent areas-Continued

\begin{tabular}{|c|c|c|c|c|}
\hline $\begin{array}{c}\text { Stratigraphic } \\
\text { unit }\end{array}$ & $\begin{array}{c}\text { Composite } \\
\text { unit }\end{array}$ & $\begin{array}{c}\text { Lithologic } \\
\text { type }\end{array}$ & $\begin{array}{c}\text { Vent } \\
\text { number }\end{array}$ & Wells \\
\hline $\mathrm{DE} 3(1)$ & 3 & Sed & & 16 \\
\hline DE3(2) & 3 & Bas & 103 & 10 \\
\hline DE3(2) & 3 & Sed & & 23 \\
\hline DE3-4(1) & 3 & Bas & 104 & 42 \\
\hline DE3-4(1) & 3 & Sed & & 4 \\
\hline DE $3-4(2)$ & 3 & Bas & 105 & 3 \\
\hline DE3-4(2) & 3 & Sed & & 8 \\
\hline DE3-4(3) & 3 & Bas & 106 & 103 \\
\hline DE3-4(3) & 3 & Sed & & 22 \\
\hline DE3-4(4) & 3 & Bas & 107 & 29 \\
\hline DE3-4(4) & 3 & Sed & & 39 \\
\hline DE3-4(5) & 3 & Bas & 108 & 13 \\
\hline DE3-4(5) & 3 & Sed & & 4 \\
\hline DE3-4(6) & 3 & Sed & & 1 \\
\hline DE4(1) & 3 & Bas & 109 & 115 \\
\hline $\mathrm{DE} 4(1)$ & 3 & Sed & & 9 \\
\hline DE4(2) & 3 & And & 110 & 2 \\
\hline DE4-5(1) & 3 & Bas & 111 & 4 \\
\hline DE4-5(1) & 3 & Sed & & 16 \\
\hline DE4-5(2) & 3 & Bas & 112 & 19 \\
\hline DE4-5(2) & 3 & Sed & & 1 \\
\hline $\mathrm{DE} 4-5(3)$ & 3 & Bas & 113 & 46 \\
\hline DE4-5(3) & 3 & Sed & & 36 \\
\hline DE4-5(4) & 3 & Bas & 114 & 10 \\
\hline DE4-5(4) & 3 & Sed & & 2 \\
\hline DE4-5(5) & 3 & Bas & 115 & 1 \\
\hline DE4-5(5) & 3 & Sed & & 2 \\
\hline DE5(1) & 4 & Bas & 116 & 122 \\
\hline DE5(1) & 4 & Sed & & 9 \\
\hline DE5-6(1) & 4 & And & 117 & 8 \\
\hline DE5-6(1) & 4 & Sed & & 1 \\
\hline DE5-6(2) & 4 & Bas & 118 & 8 \\
\hline DE5-6(3) & 4 & Bas & 119 & 3 \\
\hline DE5-6(3) & 4 & Sed & & 9 \\
\hline
\end{tabular}

\begin{tabular}{|c|c|c|c|c|}
\hline $\begin{array}{c}\text { Stratigraphic } \\
\text { unit }\end{array}$ & $\begin{array}{c}\text { Composite } \\
\text { unit }\end{array}$ & $\begin{array}{c}\text { Lithologic } \\
\text { type }\end{array}$ & $\begin{array}{c}\text { Vent } \\
\text { number }\end{array}$ & Wells \\
\hline DE5-6(4) & 4 & Bas & 120 & 7 \\
\hline DE5-6(5) & 4 & Sed & & 2 \\
\hline DE5-6(6) & 4 & Bas & 121 & 33 \\
\hline DE5-6(6) & 4 & Sed & & 71 \\
\hline DE6(1) & 4 & Bas & $122 a, b, c$ & 81 \\
\hline DE6(1) & 4 & Sed & & 25 \\
\hline DE6(2) & 4 & And & 123 & 1 \\
\hline DE6-7(1) & 4 & Bas & $124 a, b, c$ & 7 \\
\hline DE6-7(1) & 4 & Sed & & 33 \\
\hline DE7(1) & 4 & Bas & $125 \mathrm{a}, \mathrm{b}$ & 120 \\
\hline DE7(1) & 4 & Sed & & 6 \\
\hline DE7(2) & 4 & And & 126 & 1 \\
\hline DE7-8(1) & 4 & Sed & & 27 \\
\hline DE8(1) & 4 & Bas & $127 \mathrm{a}, \mathrm{b}, \mathrm{c}$ & 123 \\
\hline DE8(1) & 4 & Sed & & 4 \\
\hline DE8(2) & 4 & And & 128 & 1 \\
\hline DE9(1) & 4 & Sed & & 51 \\
\hline $\mathbf{E}(1)$ & 5 & Bas & 129 & 135 \\
\hline$E(1)$ & 5 & Sed & & 7 \\
\hline$E(2)$ & 5 & Sed & & 24 \\
\hline $\mathrm{EF}(1)$ & 5 & Bas & 130 & 96 \\
\hline $\mathrm{EF}(1)$ & 5 & Sed & & 7 \\
\hline $\mathrm{EF}(2)$ & 5 & Sed & & 5 \\
\hline$F(1)$ & 5 & Bas & 131 & 98 \\
\hline$F(1)$ & 5 & Sed & & 9 \\
\hline$F(2)$ & 5 & Sed & & 6 \\
\hline FG(1) & 6 & Bas & 132 & 84 \\
\hline $\mathrm{FG}(1)$ & 6 & Sed & & 26 \\
\hline $\mathrm{FG}(2)$ & 6 & Rhy & 133 & 0 \\
\hline $\mathrm{FG}(2)$ & 6 & Sed & & 8 \\
\hline $\mathrm{G}(1)$ & 6 & Bas & 134 & 98 \\
\hline $\mathrm{G}(1)$ & 6 & Sed & & 9 \\
\hline $\mathrm{G}(2)$ & 6 & Sed & & 3 \\
\hline $\mathrm{GH}(1)$ & 6 & Bas & 135 & 7 \\
\hline
\end{tabular}


Table 4. Stratigraphic units on or underlying the Idaho National Engineering Laboratory and adjacent areas-Continued

\begin{tabular}{|c|c|c|c|c|c|c|c|c|c|}
\hline $\begin{array}{c}\text { Stratigraphic } \\
\text { unit }\end{array}$ & $\begin{array}{l}\text { Composite } \\
\text { unit }\end{array}$ & $\begin{array}{l}\text { Lithologic } \\
\text { type }\end{array}$ & $\begin{array}{c}\text { Vent } \\
\text { number }\end{array}$ & Wells & $\begin{array}{l}\text { Stratigraphic } \\
\text { unit }\end{array}$ & $\begin{array}{l}\text { Composite } \\
\text { unit }\end{array}$ & $\begin{array}{l}\text { Lithologic } \\
\text { type }\end{array}$ & $\begin{array}{c}\text { Vent } \\
\text { number }\end{array}$ & Wells \\
\hline GH(1) & 6 & Sed & & 14 & LM3(1) & 8 & Bas & 151 & 10 \\
\hline $\mathrm{H}(1)$ & 6 & Bas & 136 & 51 & LM3(2) & 8 & Bas & 152 & 1 \\
\hline$H(1)$ & 6 & Sed & & 14 & LM3(2) & 8 & Sed & & 3 \\
\hline $\mathrm{HI}(1)$ & 6 & Bas & 137 & 11 & LM4(1) & 8 & Bas & 153 & 7 \\
\hline $\mathrm{HI}(1)$ & 6 & Sed & & 55 & LM4(1) & 8 & Sed & & 1 \\
\hline HI(2) & 6 & Sed & & 1 & LM4(2) & 8 & Bas & 154 & 0 \\
\hline I(1) & 7 & Bas & 138 & 66 & LM4(2) & 8 & Sed & & 4 \\
\hline $\mathrm{I}(1)$ & 7 & Sed & & 3 & LM4(3) & 8 & Bas & 155 & 2 \\
\hline $\mathrm{I}(2)$ & 7 & Bas & 139 & 58 & LM4(3) & 8 & Sed & & 2 \\
\hline$I(2)$ & 7 & Sed & & 2 & LM5(1) & 9 & Bas & 156 & 7 \\
\hline $\mathrm{IJ}(1)$ & 7 & Bas & 140 & 2 & LM5(2) & 9 & Bas & 157 & 0 \\
\hline $\mathrm{IJ}(1)$ & 7 & Sed & & 12 & LM5(2) & 9 & Sed & & 1 \\
\hline $\mathrm{J}(1)$ & 7 & Bas & 141 & 34 & LM5(3) & 9 & Bas & 158 & 0 \\
\hline $\mathrm{J}(1)$ & 7 & Sed & & 3 & LM6(1) & 9 & Bas & 159 & 3 \\
\hline $\mathrm{JK}(1)$ & 7 & Sed & & 3 & LM6(2) & 9 & Bas & 160 & 9 \\
\hline $\mathrm{K}(1)$ & 7 & Bas & 142 & 18 & LM6(3) & 9 & Bas & 161 & 11 \\
\hline$K(1)$ & 7 & Sed & & 6 & LM6(3) & 9 & Sed & & 2 \\
\hline $\mathrm{KL}(1)$ & 7 & Bas & 143 & 15 & $\operatorname{LM} 7(1)$ & 9 & Bas & 162 & 1 \\
\hline$K L(1)$ & 7 & Sed & & 4 & LM7(2) & 9 & Bas & 163 & 0 \\
\hline $\mathrm{KL}(2)$ & 7 & Sed & & 1 & LM7(2) & 9 & Sed & & 4 \\
\hline $\mathbf{L}(1)$ & 7 & Bas & 144 & 16 & $\mathrm{LM} 7(3)$ & 9 & Bas & 164 & 0 \\
\hline $\mathrm{L}(1)$ & 7 & Sed & & 1 & LM8(1) & 9 & Bas & 165 & 2 \\
\hline $\mathbf{L}(2)$ & 7 & Sed & & 2 & LM8(2) & 9 & Sed & & 1 \\
\hline LM1(1) & 8 & Bas & 145 & 3 & $\mathbf{M}(\mathbf{1})$ & 10 & Bas & 166 & 60 \\
\hline LM1(1) & 8 & Sed & & 7 & $\mathrm{M}(2)$ & 10 & Rhy & 167 & 0 \\
\hline LM1(2) & 8 & Bas & 146 & 3 & $M(2)$ & 10 & Sed & & 15 \\
\hline LM1(2) & 8 & Sed & & 7 & $M(2)$ & 10 & Bas & 168 & 1 \\
\hline LM1(3) & 8 & Bas & 147 & 1 & $\mathrm{MN}(1)$ & 10 & Bas & 169 & 64 \\
\hline LM1(4) & 8 & Bas & 148 & 1 & $\mathrm{MN}(2)$ & 10 & Sed & & 7 \\
\hline LM1(4) & 8 & Sed & & 2 & $N(1)$ & 10 & Bas & 170 & 64 \\
\hline $\operatorname{LM} 2(1)$ & 8 & Bas & 149 & 6 & $\mathbf{N}(2)$ & 10 & Sed & & 1 \\
\hline LM2(1) & 8 & Sed & & 2 & $N(3)$ & 10 & Bas & 171 & 1 \\
\hline LM2(2) & 8 & Bas & 150 & 0 & $N(4)$ & 10 & Bas & 172 & 2 \\
\hline LM2(2) & 8 & Sed & & 2 & $N(5)$ & 10 & Sed & & 1 \\
\hline
\end{tabular}


Table 4. Stratigraphic units on or underlying the Idaho National Engineering Laboratory and adjacent areas-Continued

\begin{tabular}{|c|c|c|c|c|c|c|c|c|c|}
\hline $\begin{array}{l}\text { Stratigraphic } \\
\text { unit }\end{array}$ & $\begin{array}{c}\text { Composite } \\
\text { unit }\end{array}$ & $\begin{array}{c}\text { Lithologic } \\
\text { type }\end{array}$ & $\begin{array}{c}\text { Vent } \\
\text { number }\end{array}$ & Wells & $\begin{array}{l}\text { Stratigraphic } \\
\text { unit }\end{array}$ & $\begin{array}{c}\text { Composite } \\
\text { unit }\end{array}$ & $\begin{array}{c}\text { Lithologic } \\
\text { type }\end{array}$ & $\begin{array}{c}\text { Vent } \\
\text { number }\end{array}$ & Wells \\
\hline NO(1) & 11 & Bas & 173 & 1 & $\mathrm{QR}(3)$ & 12 & And & 181 & 1 \\
\hline $\mathrm{NO}(1)$ & 11 & Sed & & 8 & R1(1) & 13 & Bas & 182 & 9 \\
\hline $\mathrm{O}(1)$ & 11 & Bas & 174 & 40 & R1(2) & 13 & Sed & & 10 \\
\hline $\mathrm{O}(1)$ & 11 & Sed & & 2 & R2(1) & 13 & Bas & 183 & 11 \\
\hline $\mathrm{OP}(1)$ & 11 & Sed & & 10 & $\mathrm{R} 2(2)$ & 13 & Sed & & 1 \\
\hline $\mathbf{P}(1)$ & 12 & Bas & 175 & 55 & S1(1) & 13 & Bas & 184 & 5 \\
\hline $\mathrm{P}(2)$ & 12 & Bas & 176 & 3 & S1(2) & 13 & Sed & & 1 \\
\hline $\mathrm{P}(3)$ & 12 & Bas & 177 & 1 & S2(1) & 14 & Bas & 185 & 5 \\
\hline$P Q(1)$ & 12 & Sed & & 19 & $S 2(2)$ & 14 & Sed & & 4 \\
\hline$Q(1)$ & 12 & Bas & 178 & 41 & $S 3(1)$ & 14 & Bas & 186 & 3 \\
\hline$Q(2)$ & 12 & Bas & 179 & 1 & S4(1) & 14 & Bas & 187 & 1 \\
\hline $\mathrm{QR}(1)$ & 12 & Sed & & 14 & S5(1) & 14 & Bas & 188 & 2 \\
\hline $\mathrm{QR}(2)$ & 12 & Rhy & 180 & 1 & & & & & \\
\hline
\end{tabular}


Table 5. Measured and estimated geologic ages of selected basalt-flow groups underlying the Idaho National Engineering Laboratory and adjacent areas

[Each basalt-flow group, Al(9) through TU(1), includes one or more basalt flows deposited during a single eruptive event. Measured age is analytical age determined mainly by the $\mathrm{K}$ - $\mathrm{Ar}$ method; ages for $\mathrm{Al}(9), 101 \pm 7 \mathrm{ka}$, and $\mathrm{F}(1), 550 \pm 10 \mathrm{ka}$, and $\mathrm{TU}(1), 1.865 \pm 0.024 \mathrm{ma}$, determined by thermoluminescence and ${ }^{40} \mathrm{Ar}{ }^{39} \mathrm{Ar}$ methods, respectively. Estimated age is age from Anderson and others (1997) that was estimated using all measured ages and linear accumulation rates in selected wells; line segment, (1b), indicates selected regression equation from Anderson and others (1997). Ages are listed in thousands (ka) or millions (ma) of years before present. Paleomagnetic polarity indicates normal $(N)$ or reversed $(R)$ polarity. Sample location indicates well or outcrop from which sample was obtained. Sample depth indicates depth or depth interval of core sample, in feet below land surface; letter, $\mathrm{S}$, indicates surface or near-surface sample. Hydrologic unit indicates that sample was obtained from: $1=$ the unsaturated zone, $2 U$ = the uppermost 300 feet of the Snake River Plain aquifer, $2 \mathrm{~L}=$ the lowermost part of the aquifer; or $3=$ below the effective base of the aquifer. Large differences between measured and estimated ages, such as for flow groups S1(1), S2(1), and S5(1) at TAN, indicate that additional study of these groups is needed. See table 2 for data references]

\begin{tabular}{|c|c|c|c|c|c|c|}
\hline $\begin{array}{l}\text { Basalt-flow } \\
\text { group }\end{array}$ & Measured age & $\begin{array}{l}\text { Estimated age } \\
\text { (line segment) }\end{array}$ & $\begin{array}{l}\text { Paleomagnetic } \\
\text { polarity }\end{array}$ & Sample location & $\begin{array}{l}\text { Sample } \\
\text { depth }\end{array}$ & $\begin{array}{c}\text { Hydrologic } \\
\text { unit }\end{array}$ \\
\hline \multirow[t]{2}{*}{$\mathrm{Al}(9)$} & $95 \pm 50 \mathrm{ka}$ & 100 ka (--) & $\mathbf{N}$ & BG-77-1 & 30 & 1 \\
\hline & $101 \pm 7 \mathrm{ka}$ & & $\mathrm{N}$ & RWMC & $\mathbf{s}$ & 1 \\
\hline $\mathrm{AB}(10)$ & $218 \pm 49 \mathrm{ka}$ & $198 \mathrm{ka}(1 \mathrm{a})$ & $\mathrm{N}$ & NPR Test & 23 & 1 \\
\hline $\mathrm{B}(1)$ & $<200 \mathrm{ka}$ & $221 \cdot \mathrm{ka}(1 \mathrm{a})$ & N & BG-77-1 & 81 & 1 \\
\hline $\mathrm{BC}(1)$ & $247 \pm 46 \mathrm{ka}$ & $254 \mathrm{ka}(1 \mathrm{a})$ & $N$ & NPR Test & 81 & 1 \\
\hline $\mathrm{DE} 1(2)$ & $303 \pm 30 \mathrm{ka}$ & $302 \mathrm{ka} \mathrm{(1a)}$ & $\mathbf{N}$ & NRF 89-05 & 79 & 1 \\
\hline DE2(1) & $350 \pm 40 \mathrm{ka}$ & $350 \mathrm{ka}(1 \mathrm{a}, 1 \mathrm{~b})$ & $\mathbf{N}$ & NPR Test & 157 & 1 \\
\hline DE5(1) & $441 \pm 77 \mathrm{ka}$ & $437 \mathrm{ka}(1 \mathrm{~b})$ & $\mathrm{N}$ & NPR Test & 352 & 1 \\
\hline DE8(1) & $491 \pm 80 \mathrm{ka}$ & $488 \mathrm{ka}(1 \mathrm{~b})$ & $\mathbf{N}$ & NPR Test & 444 & 1 \\
\hline $\mathrm{E}(1)$ & $515 \pm 85 \mathrm{ka}$ & $512 \mathrm{ka}(1 \mathrm{~b})$ & $\mathrm{N}$ & BG-77-1 & 300 to 329 & 1 \\
\hline$F(1)$ & $565 \pm 14 \mathrm{ka}$ & $570 \mathrm{ka}(1 \mathrm{~b})$ & $\mathbf{R}$ & BG-77-1 & 426 to 544 & 1 \\
\hline $\mathrm{FG}(1)$ & $580 \pm 93 \mathrm{ka}$ & $581 \mathrm{ka}(1 \mathrm{~b})$ & $\mathrm{N}$ & NPR Test & 508 & $2 U$ \\
\hline $\mathrm{H}(1)$ & $619 \pm 22 \mathrm{ka}$ & $619 \mathrm{ka}(1 \mathrm{~b}, 1 \mathrm{c})$ & N & USGS 123 & 540 & $2 \mathrm{U}$ \\
\hline $\mathrm{I}(1)$ & $641 \pm 54 \mathrm{ka}$ & $660 \mathrm{ka}(1 \mathrm{c})$ & $\mathrm{N}$ & NPR Test & 606 & $2 \mathrm{U}$ \\
\hline LM1(4) & $807 \pm 33 \mathrm{ka}$ & $800 \mathrm{ka}(1 \mathrm{c}, 3 \mathrm{a})$ & $\mathrm{R}$ & Richard Butte & $S$ & 1 \\
\hline LM6(3) & $939 \pm 154 \mathrm{ka}$ & $959 \mathrm{ka} \mathrm{(3a)}$ & $\mathbf{R}$ & Lava Ridge & $S$ & 1 \\
\hline$N(1)$ & $1.044 \pm 0.035 \mathrm{ma}$ & $1.152 \mathrm{ma}(3 \mathrm{~b})$ & $\mathrm{R}$ & TCH\#1 & 87 & 1 \\
\hline $\mathbf{P}(1)$ & $1.248 \pm 0.069 \mathrm{ma}$ & $1.415 \mathrm{ma}(3 \mathrm{~b})$ & $\mathbf{R}$ & TCH\#1 & 175 & 1 \\
\hline R1(1) & $1.581 \pm 0.057 \mathrm{ma}$ & $1.572 \mathrm{ma}(3 \mathrm{~b})$ & $\mathbf{R}$ & TCH\#1 & 413 & $2 \mathrm{U}$ \\
\hline S1(1) & $1.936 \pm 0.083 \mathrm{ma}$ & $1.618 \mathrm{ma}(3 \mathrm{~b})$ & $\mathbf{R}$ & TCH\#1 & 523 & $2 \mathrm{~L}$ \\
\hline$S 2(1)$ & $2.115 \pm 0.046 \mathrm{ma}$ & $1.648 \mathrm{ma}(3 \mathrm{~b})$ & $\mathrm{R}$ & TCH\#2 Piezo A & 637 & $2 \mathrm{~L}$ \\
\hline S5(1) & $2.556 \pm 0.035 \mathrm{ma}$ & $1.708 \mathrm{ma}(3 \mathrm{~b})$ & $\mathrm{R}$ & TCH\#2 Piezo A & 785 & $2 \mathrm{~L}$ \\
\hline $\mathrm{TU}(\mathbf{1})$ & $1.865 \pm 0.024 \mathrm{ma}$ & $1.790 \mathrm{ma} \mathrm{(3c)}$ & $\mathbf{N}$ & NPR WO-2 & 1708 & 3 \\
\hline
\end{tabular}


Table 6. Paleomagnetic chrons and subchrons in cores at and above the effective base of the Snake River Plain aquifer at the Idaho National Engineering Laboratory

[Paleomagnetic chrons and subchrons from Berggren and others (1995) and Champion and others (1988); letter, (B), is abbreviation used in figures 9-15. Paleomagnetic ages in thousands $(\mathrm{ka})$ or millions $(\mathrm{ma})$ of years before present. Paleomagnetic polarity indicates normal $(\mathrm{N})$ or reversed $(\mathrm{R})$ polarity. Core identifiers from table 2; identifiers in

parentheses indicate new cores from Davis and others (1997). Stratigraphic units from table 4 and Anderson and others (1996a). Depths and measured ages of polarity boundaries from Kuntz and others (1994) and data references in table 2; letters in parentheses are paleomagnetic chrons and subchrons indicated by spurious or conflicting ages. Estimated ages from Anderson and others (1997, table 6); line segment, (1b), indicates selected regression equation from Anderson and others (1997). -- indicates no data]

\begin{tabular}{|c|c|c|c|c|c|c|c|}
\hline $\begin{array}{l}\text { Paleomagnetic chron } \\
\text { or subchron }\end{array}$ & Paleomagnetic age & $\begin{array}{l}\text { Paleomagnetic } \\
\text { polarity }\end{array}$ & Core identifier & Stratigraphic unit & Depth to top (feet) & Measured age & $\begin{array}{l}\text { Estimated age } \\
\text { (line segment) }\end{array}$ \\
\hline Brunhes (B) & 0 to $780 \mathrm{ka}$ & $\mathrm{N}$ & All cores & $\mathrm{Au}(1)$ to $\mathrm{KL}(2)$ & 0 & $\begin{array}{l}5.20 \pm 0.15 \mathrm{ka} \text { to } \\
739 \pm 126 \mathrm{ka}\end{array}$ & 0 to $759 \mathrm{ka}(1 \mathrm{a}, 1 \mathrm{~b}, 1 \mathrm{c})$ \\
\hline \multirow[t]{2}{*}{ Emperor (E) } & $465 \mathrm{ka}$ & $\mathrm{R}$ & $\mathrm{NRF} \# 6 \mathrm{P}$ & DE5-6(6) & 418 & $(\mathrm{BL}, \mathrm{M})$ & $473 \mathrm{ka}(1 \mathrm{~b})$ \\
\hline & & $\mathrm{R}$ & NRF \#7P & DE5-6(6) & 428 & $(\mathrm{BL}, \mathrm{M})$ & $473 \mathrm{ka} \mathrm{(1b)}$ \\
\hline \multirow[t]{6}{*}{ Big Lost (BL) } & $550 \mathrm{ka}$ & $\mathrm{R}$ & (ARA-COR-005) & $F(1)$ & 712 & -- & $570 \mathrm{ka} \mathrm{(1b)}$ \\
\hline & & $\mathrm{R}$ & BG-77-1 & $F(1)$ & 364 & $550 \pm 10 \mathrm{ka}$ & $570 \mathrm{ka}(\mathrm{lb})$ \\
\hline & & $\mathbf{R}$ & $\mathrm{C}-1 \mathrm{~A}$ & $F(1)$ & 399 & -- & $570 \mathrm{ka}(1 \mathrm{~b})$ \\
\hline & & $\mathrm{R}$ & NPR Test & $\mathrm{F}(1)$ & 456 & -- & $570 \mathrm{ka} \mathrm{(1b)}$ \\
\hline & & $\mathrm{R}$ & (STF-PIE-AQ-01) & $\mathrm{F}(1)$ & 524 & -- & $570 \mathrm{ka}(1 \mathrm{~b})$ \\
\hline & & $\mathrm{R}$ & USGS 118 & $\mathrm{~F}(1)$ & 381 & -- & $570 \mathrm{ka}(1 \mathrm{~b})$ \\
\hline \multirow[t]{7}{*}{ Matuyama (M) } & $780 \mathrm{ka}$ to $2.58 \mathrm{ma}$ & $\mathbf{R}$ & (ANL-OBS-AQ-014) & $L(1)$ & 923 & -- & $759 \mathrm{ka}(1 \mathrm{c})$ \\
\hline & & $\mathrm{R}$ & NPR WO-2 & $L(1)$ & 767 & (B) & $759 \mathrm{ka}(1 \mathrm{c})$ \\
\hline & & $\mathrm{R}$ & $\mathrm{C}-1 \mathrm{~A}$ & LM8(1) & 703 & (B) & $1.06 \mathrm{ma}(3 \mathrm{a}, 3 \mathrm{~b})$ \\
\hline & & $\mathbf{R}$ & GIN \#5 & $\mathrm{M}(1)$ & 26 & -- & $1.08 \mathrm{ma} \mathrm{(3b)}$ \\
\hline & & $\mathrm{R}$ & GIN \#6 & $\mathrm{M}(1)$ & 57 & -- & $1.08 \mathrm{ma} \mathrm{(3b)}$ \\
\hline & & $\mathrm{R}$ & $\mathrm{TCH} \# 1$ & $\mathrm{MN}(1)$ & 44 & $1.044 \pm 0.035 \mathrm{ma}$ & $1.08 \mathrm{ma} \mathrm{(3b)}$ \\
\hline & & $\mathrm{R}$ & TCH \#2 Piezo A & $\mathrm{M}(1)$ & 40 & -- & $1.08 \mathrm{ma} \mathrm{(3b)}$ \\
\hline Jaramillo (J) & $990 \mathrm{ka}$ to $1.07 \mathrm{ma}$ & $\mathrm{N}$ & NPR WO-2 & $\operatorname{LM} 7(1)$ & 1,187 & (CM) & $991 \mathbf{k a}(3 \mathrm{a})$ \\
\hline Cobb Mountain (CM) & 1.21 to $1.24 \mathrm{ma}$ & $\mathbf{N}$ & $\mathrm{C}-1 \mathrm{~A}$ & $\mathrm{NO}(1)$ & 1,074 & $(\mathrm{M})$ & $1.23 \mathrm{ma} \mathrm{(3b)}$ \\
\hline \multirow[t]{3}{*}{ Olduvai $(\mathrm{O})$} & 1.77 to $1.95 \mathrm{ma}$ & $\mathrm{N}$ & (ANL-OBS-AQ-014) & $\mathrm{TU}(1)$ & 1,890 & -- & $1.79 \mathrm{ma} \mathrm{(3c)}$ \\
\hline & & N & Corehole 2A & $\mathrm{TU}(1)$ & 970 & (M) & $1.79 \mathrm{ma} \mathrm{(3c)}$ \\
\hline & & N & NPR WO-2 & $\mathrm{TU}(1)$ & 1,696 & $1.865 \pm 0.024 \mathrm{ma}$ & $1.79 \mathrm{ma} \mathrm{(3c)}$ \\
\hline
\end{tabular}


Table 7. Summary of composite stratigraphic units 1 through 14 in wells at and near the Idaho National Engineering Laboratory

[Composite unit is a composite stratigraphic unit in figures 9 through 30 and table 1. Number of stratigraphic units indicates the number of basalt-flow groups (Bas), sedimentary interbeds (Sed), andesite-flow groups (And), and rhyolite domes (Rhy) in a composite unit. $[\mathrm{BSB}]=$ Big Southern Butte, $[\mathrm{CB}]=$ Cedar Butte, $[\mathrm{EB}]=$ East Butte, $[\mathrm{MB}]=\mathrm{Middle}$

Butte, and [UD] = unnamed dome (figure 8). Number of wells indicates the number of wells that penetrate the top and base of a unit; altitude of top and base in feet above sea level. Geologic age is the age of a unit, in thousands (ka) or millions (ma) of years before present. Vent number indicates the location of a volcanic vent in figure 7; number in brackets indicates the location of a vent for a butte or dome in the same composite unit]

\begin{tabular}{|c|c|c|c|c|c|c|c|c|c|}
\hline $\begin{array}{c}\text { Composite } \\
\text { unit }\end{array}$ & $\begin{array}{l}\text { Number of } \\
\text { stratigraphic } \\
\text { units }\end{array}$ & $\begin{array}{l}\text { Number of } \\
\text { wells (top) }\end{array}$ & $\begin{array}{l}\text { Number } \\
\text { of wells } \\
\text { (base) }\end{array}$ & $\begin{array}{l}\text { Altitude of top } \\
\text { (feet) }\end{array}$ & $\begin{array}{l}\text { Altitude of base } \\
\text { (feet) }\end{array}$ & $\begin{array}{l}\text { Thickness } \\
\text { (feet) } \\
\text { [average] }\end{array}$ & $\begin{array}{l}\text { Sediment content } \\
\text { (percent) } \\
\text { [average] }\end{array}$ & Geologic age & $\begin{array}{c}\text { Vent } \\
\text { number }\end{array}$ \\
\hline 1 & $\begin{array}{l}78 \mathrm{Bas} \\
12 \mathrm{Sed}\end{array}$ & 333 & 326 & $5,375-4,772$ & $5,362-4,721$ & $\begin{array}{r}0-284 \\
{[62]}\end{array}$ & $\begin{array}{r}0-100 \\
{[47]}\end{array}$ & $5-250 \mathrm{ka}$ & $1-78$ \\
\hline 2 & $\begin{array}{l}18 \text { Bas } \\
13 \text { Sed } \\
1 \text { Rhy } \\
{[\text { BSB] }}\end{array}$ & 234 & 178 & $5,299-4,732$ & $5,175-4,659$ & $\begin{array}{l}0-321 \\
{[109]}\end{array}$ & $\begin{array}{r}0-100 \\
{[11]}\end{array}$ & $250-350 \mathrm{ka}$ & $\begin{array}{l}79-97 \\
{[94]}\end{array}$ \\
\hline 3 & $\begin{array}{l}17 \text { Bas } \\
17 \text { Sed } \\
1 \text { And }\end{array}$ & 164 & 143 & $5,128-4,659$ & $5,048-4,465$ & $\begin{array}{c}0-305 \\
{[164]}\end{array}$ & $\begin{array}{r}0-100 \\
{[15]}\end{array}$ & $350-440 \mathrm{ka}$ & $\begin{array}{l}98 a-115 \\
110\end{array}$ \\
\hline 4 & $\begin{array}{l}9 \text { Bas } \\
11 \text { Sed } \\
4 \text { And } \\
{[\mathrm{CB}]}\end{array}$ & 172 & 146 & $5,362-4,465$ & $5,257-4,272$ & $\begin{array}{c}0-482 \\
{[138]}\end{array}$ & $\begin{array}{r}0-100 \\
{[11]}\end{array}$ & $440-515 \mathrm{ka}$ & $\begin{array}{l}116-128 \\
{[117], 123,126,128}\end{array}$ \\
\hline 5 & $\begin{array}{l}3 \text { Bas } \\
6 \mathrm{Sed}\end{array}$ & 143 & 114 & $5,257-4,272$ & $5,059-4,093$ & $\begin{array}{c}0-329 \\
{[125]}\end{array}$ & $\begin{array}{r}0-100 \\
{[5]}\end{array}$ & $515-580 \mathrm{ka}$ & $129-131$ \\
\hline 6 & $\begin{array}{l}5 \text { Bas } \\
8 \text { Sed } \\
1 \text { Rhy } \\
{[E B]}\end{array}$ & 118 & 68 & $5,089-4,093$ & $4,876-3,939$ & $\begin{array}{l}0-347 \\
{[107]}\end{array}$ & $\begin{array}{r}0-100 \\
{[23]}\end{array}$ & $580-650 \mathrm{ka}$ & $\begin{array}{l}132-137 \\
{[133]}\end{array}$ \\
\hline 7 & $\begin{array}{l}7 \text { Bas } \\
10 \text { Sed }\end{array}$ & 70 & 15 & $4,876-3,939$ & $4,592-3,807$ & $\begin{array}{l}0-409 \\
{[266]}\end{array}$ & $\begin{array}{l}0-59 \\
{[13]}\end{array}$ & $650-800 \mathrm{ka}$ & $138-144$ \\
\hline $8-14$ & $\begin{array}{c}41 \text { Bas } \\
26 \text { Sed } \\
1 \text { And } \\
2 \text { Rhy } \\
\text { [MB, UD] }\end{array}$ & 86 & 9 & $4,978-3,807$ & $4,017-3,260$ & $\begin{array}{r}0->1,609 \\
{[832]}\end{array}$ & $\begin{array}{r}4-13 \\
{[7]}\end{array}$ & $0.8-1.8 \mathrm{ma}$ & $\begin{array}{l}145-188 \\
181 \\
{[167,180]}\end{array}$ \\
\hline
\end{tabular}


Table 8. Measured and estimated geologic ages of selected surficial stratigraphic units at and near the Idaho National Engineering Laboratory

[Stratigraphic unit is a basalt-flow group from table 4. Vent number corresponds to volcanic vent in figure 7. Field number, flow name, and map unit correspond to number, name, and unit of a basalt-flow group on the geologic map of the INEL and adjoining areas (Kuntz and others, 1994). Measured age, $519 \pm 52 \mathrm{ka}$, is K-Ar age of unit reported by Kuntz and others (1994), in thousands of years before present (ka); remeasured age, [ $292 \pm 58 \mathrm{ka}$ ], is revised K-Ar age of unit AB(8) (M.A. Lanphere, USGS, written commun., 1994). Alternative stratigraphic unit is alternative unit from table 4 indicated by measured age. Estimated age is from Anderson and others (1997, table 6). Alternative map unit is alternative unit from Kuntz and others (1994) indicated by estimated age; -- indicates no alternative map unit required]

\begin{tabular}{|c|c|c|c|c|c|c|c|c|}
\hline $\begin{array}{c}\text { Stratigraphic } \\
\text { unit }\end{array}$ & $\begin{array}{c}\text { Vent } \\
\text { number }\end{array}$ & $\begin{array}{c}\text { Field } \\
\text { number }\end{array}$ & Flow name & $\begin{array}{l}\text { Map } \\
\text { unit }\end{array}$ & $\begin{array}{l}\text { Measured age } \\
\text { [remeasured] }\end{array}$ & $\begin{array}{c}\text { Alternative } \\
\text { stratigraphic } \\
\text { unit }\end{array}$ & $\begin{array}{l}\text { Estimated } \\
\text { age }\end{array}$ & $\begin{array}{c}\text { Alter- } \\
\text { native } \\
\text { map } \\
\text { unit }\end{array}$ \\
\hline $\mathrm{AB}(8)$ & 23 & 841 Le-20 & Crater Butte & Qbd & $\begin{array}{c}519 \pm 52 \mathrm{ka} \\
{[292 \pm 58 \mathrm{ka}]}\end{array}$ & $\begin{array}{l}\mathrm{E}(1) \\
{[\mathrm{DE} 1(2)]}\end{array}$ & 198 to $221 \mathrm{ka}$ & Qbc \\
\hline $\mathrm{AB}(13)$ & 28 & 841Le-1 & Kettle Butte & Qbc & $316 \pm 75 \mathrm{ka}$ & DE1(2) & 198 to $221 \mathrm{ka}$ & - \\
\hline $\mathrm{AB}(37)$ & 52 & 841Le-15 & Taber Butte & Qbb & $165 \pm 22 \mathrm{ka}$ & $\mathrm{Al}(14)$ & 198 to $221 \mathrm{ka}$ & $\mathrm{Qbc}$ \\
\hline $\mathrm{AB}(38)$ & 53 & 841Le-17 & Vent 5183 flow & Qbd & $454 \pm 28 \mathrm{ka}$ & DE5-6(1) & 198 to $221 \mathrm{ka}$ & Qbc \\
\hline $\mathrm{B}(1)$ & 74 & (none) & $\begin{array}{l}\text { Vent } 5206, \text { flow north } \\
\text { of Big Southern Butte }\end{array}$ & Qbb & $<200 \mathrm{ka}$ & $\mathrm{Al}(15)$ & $221 \mathrm{ka}$ & Qbc \\
\hline DE1(1) & 90 & 84ILe-24 & State Butte & Qbd & $579 \pm 130 \mathrm{ka}$ & $\mathrm{FG}(1)$ & $302 \mathrm{ka}$ & Qbc \\
\hline DE6(1) & $122 a$ & $84 \mathrm{Le}-30$ & $\begin{array}{l}\text { Unnamed flow, Arco- } \\
\text { Big Southern rift zone }\end{array}$ & Qbd & $609 \pm 92 \mathrm{ka}$ & $\mathrm{H}(1)$ & $473 \mathrm{ka}$ & -- \\
\hline
\end{tabular}


Table 9. Average sediment content of composite stratigraphic units 1 through 7 in selected wells east through southwest of Test Area North at the Idaho National Engineering Laboratory

[Well is one that is located in a zone of steep water-level gradients (Bartholomay and others, 1995) and thick surficial sediment (Anderson and others, 1996b). Map number indicates location of well in figure 2. Composite units are composite stratigraphic units in figures 9 through 28 and in table 4 . Total thickness, number of sediment layers, and total sediment thickness from Anderson and others (1996a, table 6). Average sediment content is the total sediment thickness divided by the total thickness, in percent; number in brackets indicates content for saturated interval in 1989-90. Average sediment content for all INEL wells is a weighted average determined from the average content of each composite unit in all 333 wells evaluated for stratigraphic relations at and near the INEL. -- indicates no data or not applicable]

\begin{tabular}{lcccccc}
\hline Well & $\begin{array}{c}\text { Map } \\
\text { number }\end{array}$ & $\begin{array}{c}\text { Composite } \\
\text { units }\end{array}$ & $\begin{array}{c}\text { Total thickness } \\
\text { (feet) }\end{array}$ & $\begin{array}{c}\text { Number of } \\
\text { sediment layers }\end{array}$ & $\begin{array}{c}\text { Total sediment } \\
\text { thickness (feet) }\end{array}$ & $\begin{array}{c}\text { Average sediment } \\
\text { content (percent) } \\
\text { [saturated interval] }\end{array}$ \\
\hline USGS 18 & 17 & $1-4$ & 254 & 6 & 181 & $71[--]$ \\
USGS 27 & 26 & $1-4$ & 312 & 8 & 154 & $49[15]$ \\
USGS 28 & 27 & $1-4$ & 334 & 4 & 55 & $16[8]$ \\
USGS 31 & 30 & $1-5$ & 428 & 5 & 62 & $14[6]$ \\
Ashcraft & 142 & $1-6$ & 420 & 12 & 188 & $45[29]$ \\
Barney North & 152 & $1-7$ & 660 & 9 & 172 & $26[7]$ \\
Bamey South & 153 & $1-7$ & 596 & 9 & 167 & $28[15]$ \\
Callaway & 172 & $1-7$ & 650 & 10 & 265 & $41[43]$ \\
Cope & 174 & $1-7$ & 784 & 11 & 249 & $32[22]$ \\
Corehole 2A & 176 & $1-4$ & 244 & 6 & 182 & $74[100]$ \\
DH1B & 179 & $1-4$ & 400 & 17 & 348 & $87[100]$ \\
DH2A & 180 & $1-5$ & 430 & 16 & 339 & $79[83]$ \\
DH3 & 181 & $1-3$ & 203 & 12 & 203 & $100[-]$ \\
Site 14 & 286 & $1-7$ & 717 & 19 & 395 & $55[28]$ \\
All INEL wells & $1-335$ & $1-7$ & -- & - & & $15[-]$ \\
\hline
\end{tabular}

